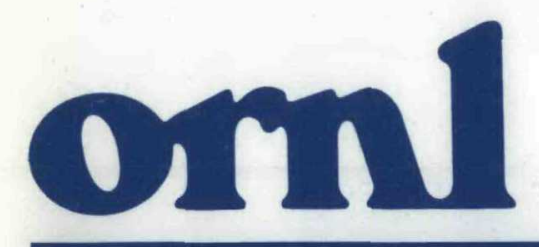

OAK

RIDGE

NATIONAL

LABORATORY

UNION

CARBIDE
NUREG/CR-1767

ORNL/NUREG/TM-408

\title{
Sodium Oxide and Uranium Oxide Aerosol Experiments: NSPP Tests 106-108 and Tests 204-207. Data Record Report
}

\author{
R. E. Adams
}

T. S. Kress

M. L. Tobias

Prepared for the U.S. Nuclear Regulatory Commission Office of Nuclear Regulatory Research

OPERATED BY

UNION CARBIDE CORPORATION

FOR THE UNITED STATES

DEPARTMENT OF ENERGY 


\section{DISCLAIMER}

This report was prepared as an account of work sponsored by an agency of the United States Government. Neither the United States Government nor any agency Thereof, nor any of their employees, makes any warranty, express or implied, or assumes any legal liability or responsibility for the accuracy, completeness, or usefulness of any information, apparatus, product, or process disclosed, or represents that its use would not infringe privately owned rights. Reference herein to any specific commercial product, process, or service by trade name, trademark, manufacturer, or otherwise does not necessarily constitute or imply its endorsement, recommendation, or favoring by the United States Government or any agency thereof. The views and opinions of authors expressed herein do not necessarily state or reflect those of the United States Government or any agency thereof. 


\section{DISCLAIMER}

Portions of this document may be illegible in electronic image products. Images are produced from the best available original document. 


\title{
Printed in the United States of America. Available from National Technical Information Service \\ U.S. Department of Commerce 5285 Port Royal Road, Springfield, Virginia 22161
}

\author{
Available from \\ GPO Sales Program \\ Division of Technical Information and Document Control \\ U.S. Nuclear Regulatory Commission \\ Washington, D.C. 20555
}

This report was prepared as an account of work sponsored by an agency of the United States Government. Neither the United States Government nor any agency thereof, nor any of their employees, makes any warranty, express or implied, or assumes any legal liability or responsibility for the accuracy, completeness, or usefulness of any information, apparatus, product, or process disclosed, or represents that its use would not infringe privately owned rights. Reference herein to any specific commercial product, process, or service by trade name, trademark, manufacturer, or otherwise, does not necessarily constitute or imply its endorsement, recommendation, or favoring by the United States Government or any agency thereof. The views and opinions of authors expressed herein do not necessarily state or reflect those of the United States Government or any agency thereof.

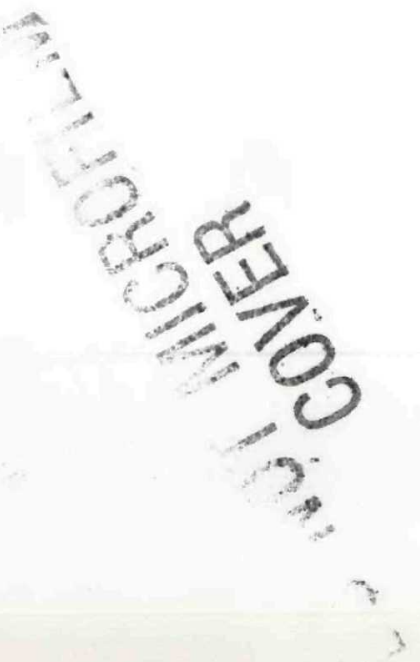




\title{
SODIUM OXIDE AND URANIUM OXIDE AEROSOL EXPERIMENTS: NSPP TESTS 106-108 AND TESTS 204-207, DATA RECORD REPORT
}

R. E. Adams

\author{
T. S. Kress \\ M. I Tobias
}

\begin{abstract}
Manuscript Completed - January 30, 1981
Date Published - March 1981
\end{abstract}

NOTICE This document contains information of a prelımınary nature. It is subject to revision or correction and therefore does not represent a final report

\author{
Prepared for the \\ U S Nuclear Regulatory Commission \\ Office of Nuclear Regulatory Research \\ Under Interagency Agreements DOE 40-551-75 and 40-552-75
}

NRC FIN No. B0121

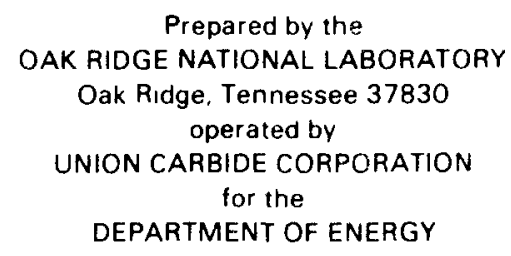




\section{CONTENTS}

Page

SUMMARY

$\mathrm{v}$

ABSTRACT .

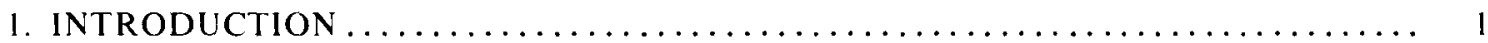

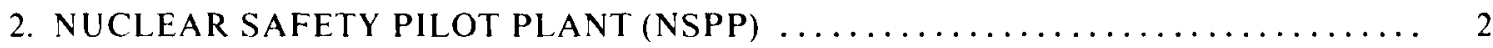

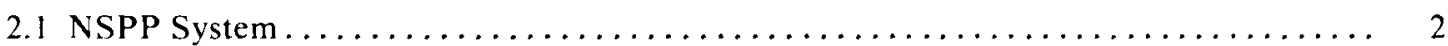

2.1.1 Equipment for measurement of aerosol parameters $\ldots \ldots \ldots \ldots \ldots \ldots \ldots .2$

2.1.2 Equipment for measurement of system parameters................. 4

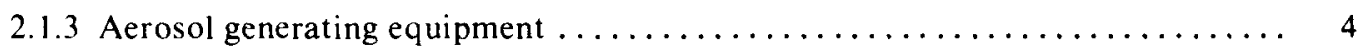

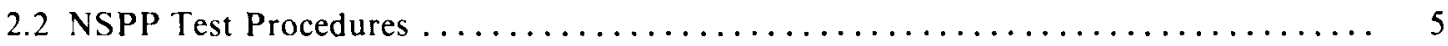

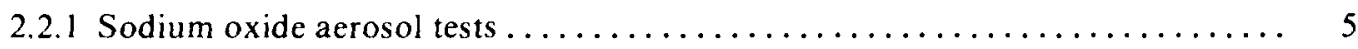

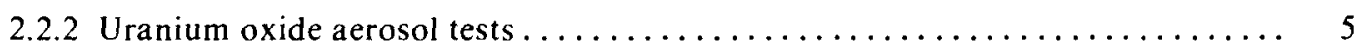

3. DESCRIPTION OF INDIVIDUAL AEROSOL TESTS $\ldots \ldots \ldots \ldots \ldots \ldots \ldots \ldots \ldots \ldots \ldots$

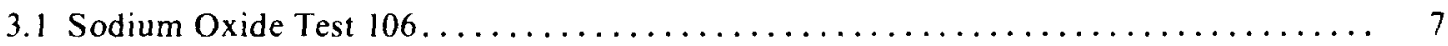

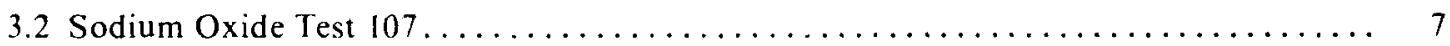

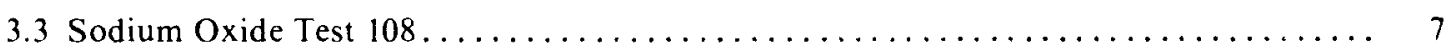

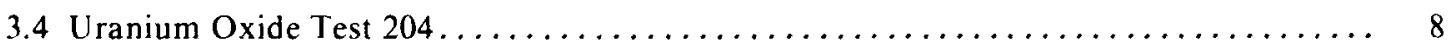

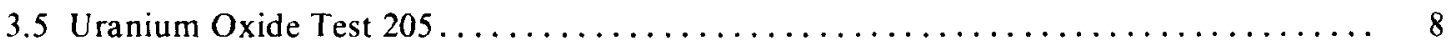

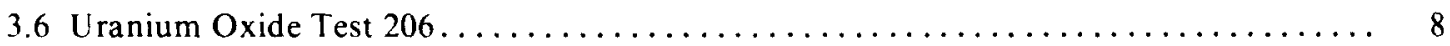

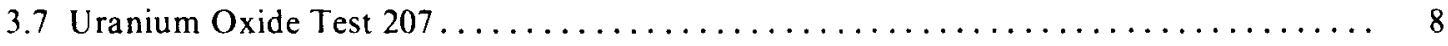

4. RESULTS FROM INDIVIDUAL AEROSOL TESTS $\ldots \ldots \ldots \ldots \ldots \ldots \ldots \ldots \ldots$

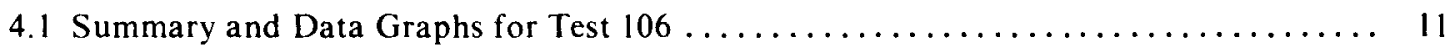

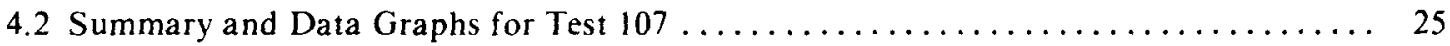

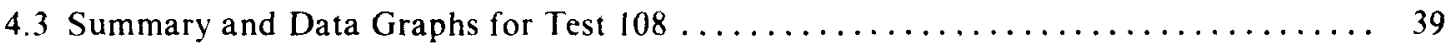

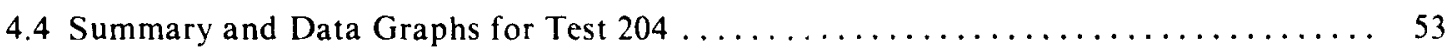

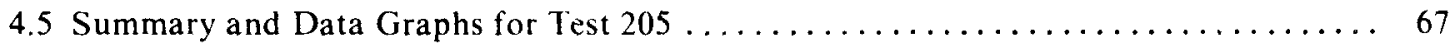

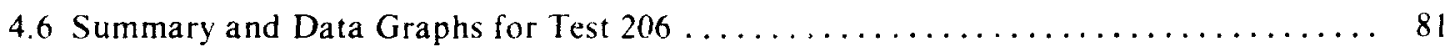

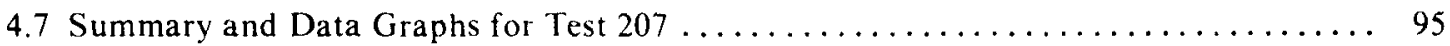

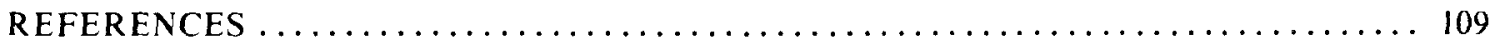




\section{SUMMARY}

This data record report summarizes results from three sodium oxide aerosol behavior tests and four uranium oxide aerosol behavior tests in the Nuclear Safety Pilot Plant (NSPP) project, which is part of the Aerosol Release and Transport (ART) program at Oak Ridge National Laboratory (ORNL), sponsored by the Nuclear Regulatory Commission-Advanced Reactor Safety Research (NRC-ARSR). The sodium oxide aerosol tests constitute a continuation of a planned series of tests utilizing both sodium spray and sodium pool fires as sources of aerosol. The uranium oxide aerosol tests are also a continuation of a planned series. The uranium oxide aerosol was generated by a new techniq ue using an argon plasma metallizing torch, which produced higher aerosol mass concentrations than heretofore possible with the previous generation technique. These data on sodium oxide and uranium oxide aerosol behaviors will be used along with future NSPP data to provide experimental validation of aerosol behavioral models being developed for NRC-ARSR.

Of the three sodium oxide aerosol tests, two involved sodium spray fires and the other, a sodium pool fire. Aerosol mass concentration in the $40-$ to $45-\mu \mathrm{g} / \mathrm{cm}^{3}$ range was achieved by the spray fires; the small sodium pool fire test, which produced an aerosol concentration of $2.3 \mu \mathrm{g} / \mathrm{cm}^{3}$, was intended to supplement previous tests in the 6- to $25-\mu \mathrm{g} / \mathrm{cm}^{3}$ concentration range. The four uranium oxide aerosol tests covered an aerosol concentration range from 0.7 to $5.6 \mu \mathrm{g} / \mathrm{cm}^{3}$ and supplemented previous tests performed in the $0.04-$ to $0.20-\mu \mathrm{g} / \mathrm{cm}^{3}$ range.

In this data record report, a brief description of each test and its results in the form of tables and graphs is given. Included are data on aerosol mass concentration, aerosol fallout rate, aerosol plateout rate, cumulative mass fallout and plateout, aerosol particle size, vessel atmosphere pressure, vessel atmosphere temperatures, thermal gradients near the vessel wall, and final aerosol distribution within the vessel at the termination of the test. 


\title{
SODIUM OXIDE AND URANIUM OXIDE AEROSOL EXPERIMENTS: NSPP TESTS 106-108 AND TESTS 204-207, DATA RECORD REPORT
}

R. E. Adams

\author{
T. S. Kress M. L. Tobias
}

\begin{abstract}
This data record report describes three sodium oxide aerosol tests and four uranium oxide aerosol tests conducted in the Nuclear Safety Pilot Plant project at Oak Ridge National Laboratory. The goal of this project is to establish the validity (or level of conservatism) of the aerosol behavioral code, HAARM-3, and follow-on codes under development at the Battelle Columbus Laboratories for the U.S. Nuclear Regulatory Commission. Descriptions of the seven tests with tables and graphs summarizing the results are included.
\end{abstract}

\section{INTRODUCTION}

The Nuclear Safety Pilot Plant (NSPP) project is part of the Aerosol Release and Transport (ART) program at Oak Ridge National Laboratory (ORNL), sponsored by the Nuclear Regulatory Commission-Advanced Reactor Safety Research (NRC-ARSR). The NSPP project involves studying the behavior in secondary containment environments of aerosols released under liquid-metal-cooled fast breeder reactor (LMFBR) accident conditions. These accident conditions involve mixtures of aerosols containing (1) both fuel and sodium oxides, (2) relatively high aerosol concentration, (3) temperature and pressure transients due to sodium burning, (4) possible presence of moisture in the secondary containment air atmosphere, and (5) continuous as well as instantaneous sources of aerosol.

The NSPP program presently focuses on establishing the validity (or level of conservatism) of the aerosol behavioral code, HAARM-3, and follow-on codes under development for NRC at Battelle Columbus Laboratories. Special emphasis is placed on the applicability of the codes for describing the behavior of mixtures of aerosols and on the model features related to the effects of vessel size.

The test program provides for single-component aerosol tests using either sodium oxides or uranium oxides to simulate fuel oxide aerosols. These tests will be followed by two-component aerosol tests in which sodium oxides and uranium oxides will be mixed in varying proportions and time sequences to study the interaction of the two individual aerosols as well as the composite behavior of the aerosol mixture. Previous data record reports ${ }^{1,2}$ covered the first five sodium oxide aerosol tests, the first four uranium oxide aerosol tests, and two preliminary mixed uranium oxide-sodium oxide aerosol tests. This report covers three additional sodium oxide tests and four additional uranium oxide tests which utilized a new aerosol generator. Future reports in this series will cover two-component mixed oxide aerosol tests and additional special-purpose single-component aerosol tests. 


\section{NUCLEAR SAFETY PILOT PLANT (NSPP)}

\subsection{NSPP System}

The NSPP is composed of a test vessel, aerosol generating equipment, analytical sampling and system parameter measurıng equipment, and a liquid spray decontamınatıng system A schematıc representation of the system is given in Fig 1 The NSPP vessel is a stainless steel cylinder with dished

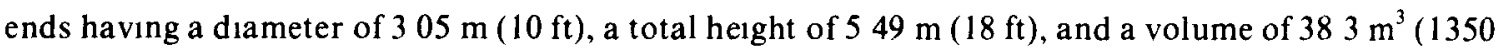
$\left.\mathrm{ft}^{3}\right)$ The wall thickness of the vessel is $953 \mathrm{~mm}(0375 \mathrm{in})$, the floor area $1 \mathrm{~s} 77 \mathrm{~m}^{2}\left(829 \mathrm{ft}^{2}\right)$, and the internal surface area (including top and floor) is $689 \mathrm{~m}^{2}\left(7416 \mathrm{ft}^{2}\right)$ The design temperature limitation is $150^{\circ} \mathrm{C}$, while the design pressure limitation is $041 \mathrm{MPa}(60 \mathrm{psia})$

\subsubsection{Equipment for measurement of aerosol parameters}

Aerosol mass concentration. Aerosol mass concentratıons are obtained with two types of filter samplers The in-vessel sampler is a self-contained unit with 12 filter tubes, a sequential valve, and a stepping motor, mechanical operation of this sampler is remote from the control room The other type, the wall aerosol sampler (so-called because the sampler penetrates the vessel wall through a ball valve and flange arrangement), is inserted and retrieved manually The sampling procedure for either type of sampler requires drawing a measured volume of containment vessel atmosphere through a sampling pack that contains four membrane filters in series The filter material is Millipore Fluoropore with a 0 5-pore size The quantity of uranium on each filter paper and associated metal parts is determined by a fluorometric technique, the quantity of sodium is determined by atomic absorption spectroscopy

The locations of the four in-vessel samplers and the three wall aerosol samplers are noted in Table 1

Table 1. Locations of aerosol mass concentration samplers

\begin{tabular}{|c|c|c|c|}
\hline Sampler & $\begin{array}{c}\text { Radial } \\
\text { direction }\end{array}$ & $\begin{array}{c}\text { Distance from } \\
\text { bottom } \\
{[\mathrm{m}(\mathrm{ft})]}\end{array}$ & $\begin{array}{l}\text { Radial distance } \\
\text { from centerline }\end{array}$ \\
\hline In-vessel 151 & East & $415(136)$ & $058 \mathrm{~m}(190 \mathrm{ft})$ \\
\hline In-vessel 152 & Southeast & $415(136)$ & $106 \mathrm{~m} \mathrm{(348 \textrm {ft } )}$ \\
\hline In-vessel 153 & East & $280(92)$ & $109 \mathrm{~m}(358 \mathrm{ft})$ \\
\hline In-vessel 154 & Southeast & $134(44)$ & $111 \mathrm{~m} \mathrm{(364ft)}$ \\
\hline Wall 155 & South & $415(136)$ & $061 \mathrm{~m}(20 \mathrm{ft})$ \\
\hline Wall 156 & Southeast & $280(92)$ & $25 \mathrm{~mm}$ ( $1 \mathrm{in})$ from wall \\
\hline Wall 157 & Southwest & $280(92)$ & $106 \mathrm{~m} \mathrm{(348 \textrm {ft } )}$ \\
\hline
\end{tabular}

Aerosol fallout rate. Aerosol fallout rate is determined with an incremental, retrievable coupon sampler This system also penetrates the vessel wall through a ball valve and flange arrangement The sampler is located in the southwest quadrant at $51 \mathrm{~mm}(2 \mathrm{in})$ from the vessel wall and is $\sim 056 \mathrm{~m}(183$ $\mathrm{ft}$ ) above the low point of the vessel floor

Aerosol plateout rate. Aerosol plateout rate is determined with an incremental, retrievable coupon sampler, the coupon, which is in the form of a disk, fits flush with the vessel wall This system penetrates the vessel wall through a ball valve and flange arrangement and is located in the northeast

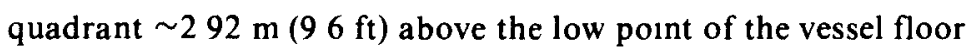




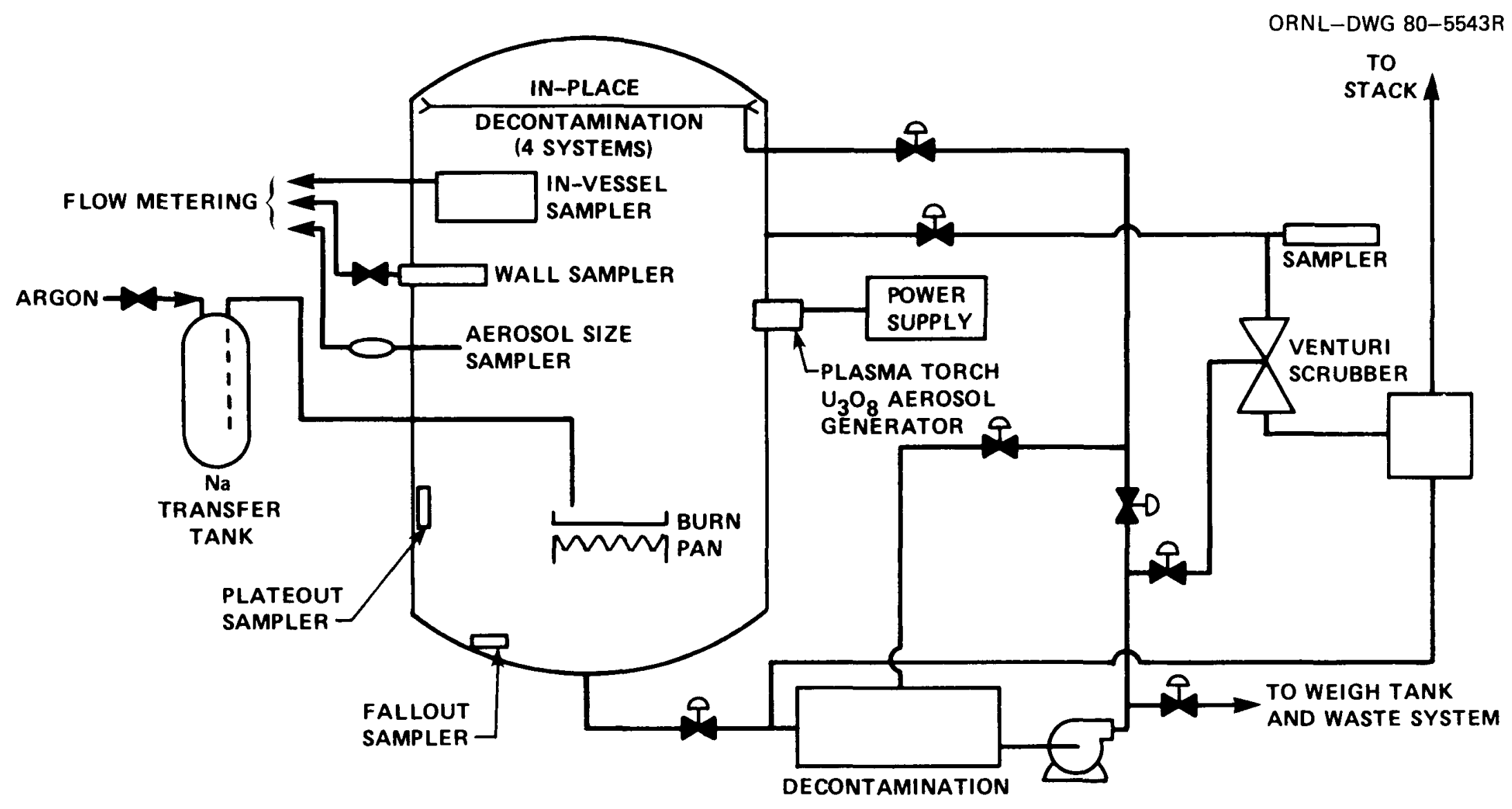

Fig. 1. Nuclear Safety Pilot Plant (NSPP) flow sheet. 
Total fallout collectors. Total fallout is determined with six shallow dishes, $65 \mathrm{~mm}$ diam (2 $56 \mathrm{in}$ ), placed along a vessel radius near the bottom of the vessel within the northwest quadrant The dishes are placed $\sim 30 \mathrm{~mm}(12 \mathrm{nn})$ apart, the edge of the first dish is $13 \mathrm{~mm}(05 \mathrm{in})$ from the wall The exposed collectors are retrieved with remote tools at the end of sampling operations before hquid spray decontamination of the vessel interior

Total plateout collectors. Total plateout is determıned with three flat disks, $61 \mathrm{~mm}$ diam ( $238 \mathrm{in})$, mounted flat on the vessel wall One disk is mounted on the east side of the vessel at an elevation of 076 $\mathrm{m}(25 \mathrm{ft})$ from the low point of the vessel bottom The other two disks are mounted on the west side of the vessel, 076 and $267 \mathrm{~m} \mathrm{(25}$ and $875 \mathrm{ft}$ ), respectively, from the bottom of the vessel These exposed disks are also retrieved with remote tools along with the total fallout collectors

Aerosol particle size. Aerodynamic particle size is measured with a cascade impactor (Andersen Mark III Particle Sizing Stack Sampler) This is an eight-stage impactor, operating at a gas flow of 236 $\times 10^{4} \mathrm{~m}^{3} / \mathrm{s}(05 \mathrm{cfm})$, and covers the aerodynamic particle diameter range from 054 to $136 \mu \mathrm{m}$ The sampling location is in the southwest quadrant at $0457 \mathrm{~m}$ ( $15 \mathrm{ft}$ ) from the vessel wall at $\sim 29 \mathrm{~m}(96 \mathrm{ft})$ from the low point of the vessel floor

During the uranium oxide aerosol tests. samples are taken at the same location for electron microscopy The aerosol is deposited onto carbon-coated copper grids using a Model 3100 Electrostatic Aerosol Sampler (Thermo-Systems, Inc)

\subsubsection{Equipment for measurement of system parameters}

Temperature of the vessel atmosphere. Twelve thermocouples (Chromel-Alumel) are used for the measurement of the vessel atmospheric temperatures At each of three elevations in the vessel, there are four thermocouples, with one placed in each quadrant The elevations are 122,274 , and $427 \mathrm{~m}(4,9$, and $14 \mathrm{ft}$ ) Thermocouple responses are recorded with both strip-chart recorders and a Digitrend data logger

Wall temperature gradients. Two thermocouple arrays, each having five thermocouples, are mounted near the wall, one at $27-\mathrm{m}(9-\mathrm{ft})$ elevation on the east radius and the other at $12-\mathrm{m}(4-\mathrm{ft})$ elevation on the north radius The thermocouples in each array are located at $10,5,25$, and $125 \mathrm{~mm}$ (0 39,0 2,0 1, and $005 \mathrm{in}$ ) distance from the wall and on the wall surface, a sixth thermocouple is located on the outer surface of the vessel at approximately the same location Thermocouple responses are recorded with both strip-chart recorders and the Digitrend data logger

Vessel gas pressure. Vessel gas pressure is measured with a pressure cell The pneumatic signal is converted to an equivalent electrical signal and recorded on a strip-chart recorder and with the Digit rend data logger

\subsubsection{Aerosol generating equipment}

Sodium oxide aerosols. Two methods were used to produce sodium oxıde aerosols First, to sımulate an aerosol produced by a sodium spray fire, heated sodium metal at $773 \mathrm{~K}\left(500^{\circ} \mathrm{C}\right)$ was injected into the test vessel via a single spray nozzle centrally located in the upper region of the vessel At

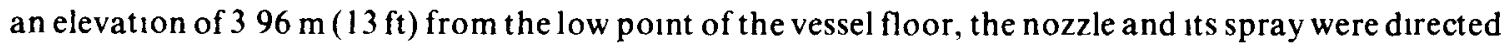
downward The average sodium droplet diameter, estimated from the manufacturer's literature on water sprays, was approxımately $480 \mu \mathrm{m}$ 
Using the second method, sodium oxide aerosols from a pool fire were produced by injecting heated sodium at $773 \mathrm{~K}\left(500^{\circ} \mathrm{C}\right)$ int 0 a preheated burn pan $\left[0.5 \mathrm{~m}^{2}\left(5.34 \mathrm{ft}^{2}\right)\right]$ located near the bottom of the vessel.

Uranium oxide aerosols. In previous tests, the uranium oxide aerosol was generated by consuming a uranium metal electrode in a $\mathrm{dc}$ arc. ${ }^{2}$ The aerosol concentration produced was low, 0.2 $\mu \mathrm{g} / \mathrm{cm}^{3}$ or less. For the tests covered in this report, an alternate generation method, developed by another group within the ART program, ${ }^{3}$ was adapted to the NSPP system. Essentially, the generator is composed of a METCO Model 7M Plasma Flame Spray System and a special water-cooled combustion adapter head through which uranium metal powder and oxygen gas are added to the argon plasma flame. The resulting mix of high temperature, uranium metal vapor, and oxygen combine to produce an aerosol of uranium oxide $\left(\mathrm{U}_{3} \mathrm{O}_{8}\right)$. With this generator, aerosol concentrations up to about 6 $\mu \mathrm{g} / \mathrm{cm}^{3}$ have been achieved.

\subsection{NSPP Test Procedures}

\subsubsection{Sodium oxide aerosol tests}

Each of the sodium oxide aerosol tests has followed essentially the same procedure. The vessel atmosphere was air at an initial relative humidity of $<20 \%$. The sodium inventory, contained in the sodium transfer tank, is heated to about $773 \mathrm{~K}\left(500^{\circ} \mathrm{C}\right)$ and then transferred to the heated spray nozzle or heated sodium burn pan by argon gas pressure. The resulting sodium oxidation produces the oxide aerosol, and its behavior is monitored for $24 \mathrm{~h}$ (Tests 106 and 107) or $48 \mathrm{~h}$ (Test 108). The burn pan was allowed to cool to about $473 \mathrm{~K}\left(200^{\circ} \mathrm{C}\right)$ and then maintained at that temperature for about $10 \mathrm{~h}$ to maintain convection currents and to ensure mixing of the aerosol. At the conclusion of the 24-h test period, the vessel is purged with dry filtered compressed air; all gases leaving the vessel are discharged into the off-gas disposal stack by way of a water scrubber. During this step, a gas sample is taken through a filter pack to determine the amount of sodium oxide aerosol contained in these gases. This step is omitted when the test duration is $48 \mathrm{~h}$; the amount of aerosol remaining airborne at $48 \mathrm{~h}$ is inconsequential. Next, the top of the vessel is opened and the various samplers within the vessel are removed and photographs are taken of the interior. The top is replaced, and the vessel atmosphere is purged with nitrogen to reduce the oxygen concentration to $<4 \%$ prior to operation of the water sprays for vessel decontamination. The lowered oxygen concentration ensures against an energetic hydrogenoxygen recombination in the event any unoxidized sodium metal remains in the burn pan. The water spray decontamination proceeds sequentially from the vessel floor to the sodium burn pan, the vessel walls, and the top head of the vessel. Each batch of decon water and rinse water is weighed and sampled for analysis prior to disposal. From these data, a sodium material balance is obtained.

All of the aerosol sampling devices (filter packs, impactors, coupons) are disassembled, packaged, and submitted to the ORNL analytical laboratory where the sodium content of each sample is determined by atomic absorption spectroscopy.

\subsubsection{Uranium oxide aerosol tests}

Each of the four uranium oxide aerosol tests has also followed essentially the same procedure. The vessel atmosphere was air at an initial relative humidity of $<20 \%$. Uranium oxide aerosol $\left(\mathrm{U}_{3} \mathrm{O}_{8}\right)$ is produced with the plasma torch generator, and the behavior of the aerosol within the vessel is 
monitored for $48 \mathrm{~h}$ The sodium burn pan, heated to a temperature of approximately $473 \mathrm{~K}\left(200^{\circ} \mathrm{C}\right)$, is utılized to maintain convection currents within the vessel over the first $10 \mathrm{~h}$ of the test to ensure mxing of the aerosol At the conclusion of the test period, the samplers are removed and photographs are taken as in the sodium oxide tests The interior surfaces of the vessel are then remotely decontaminated with a heated solution which is a mixture of oxalic actd, hydrogen peroxide, ammonium citrate, ammonium hydroxide, and water The spray decontamination proceeds sequentially from the vessel floor to the burn pan, the walls, and the top head of the vessel Each batch of decon solution and rinse water is weighed and sampled for analysis prior to disposal All of the sampling devices are disassembled, packaged, and submitted for uranium analysis by a fluorometric technique 


\section{DESCRIPTION OF INDIVIDUAL AEROSOL TESTS}

\subsection{Sodium Oxide Test 106}

This was the second sodium spray fire test performed in the NSPP The first test, 'designated Test 105 , utılized a sodium spray system centrally mounted near the bottom of the vessel with spray directed upward Results from that test were inconclusive For this test, the single spray nozzle was centrally located in the upper region of the vessel with spray directed downward Approximately $5 \mathrm{~kg}$ (11 lb) of heated sodıum was injected into the relatively dry (ınıtial relatıve humıdity $<20 \%$ ) vessel atmosphere over a perıod of $3 \mathrm{~min}$ The observed pressure rise because of the burnıng sodıum was $0038 \mathrm{MPa}$ (5 5 psi), a vertical temperature gradient existed for a short period of time with maximum temperatures of 653,573 , and $413 \mathrm{~K}\left(380,300\right.$, and $\left.140^{\circ} \mathrm{C}\right)$ measured in the upper, middle, and lower regions of the vessel Approximately $10 \mathrm{~min}$ after termination of the sodium spray, the pressure and temperature transients had disappeared Early aerosol mass samples were not obtained because of a malfunction of the ın-vessel samplıng system Posttest examination revealed that electrical control had been lost as a result of the impact of burning sodium on some exposed electrical wirıng The first filter samples were taken with wall aerosol samplers at 17 min after start of sodium injection The average sodium oxıde aerosol mass concentration at that time was found to be $42 \mu \mathrm{g} / \mathrm{cm}^{3}$ By extrapolation to the time of termination of the sodium spray, an estımated maximum concentratıon of approxımately $45 \mu \mathrm{g} / \mathrm{cm}^{3}$ may be obtained Sampling operations for aerosol particle diameter and fallout and plateout rates were more successful Test duration was $25 \mathrm{~h}$

\subsection{Sodium Oxide Test 107}

This test was conducted in a manner similar to that for Test 106 The sodium oxide aerosol was produced by injecting $10 \mathrm{~kg}(22 \mathrm{lb})$ of heated sodium through the single spray nozzle over a period of 65 min The observed pressure rise was $0043 \mathrm{MPa}(63 \mathrm{ps}$ ), again a vertical temperature gradient was produced for a short period of time with maximum temperatures of 689,643 , and $480 \mathrm{~K}(416,370$, and $207^{\circ} \mathrm{C}$ ) measured in the upper, middle, and lower regions of the vessel Approximately 14 min after termınation of the sodıum spray, the pressure and temperature gradients had disappeared The first set of in-vessel filter samples was taken at 25 min after spray termınation Again, electrical problems developed in three of the four in-vessel samplers because of the exposure to high temperatures The

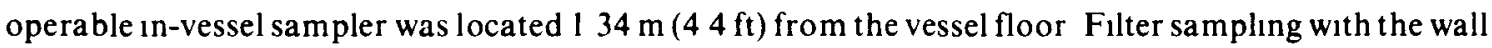
samplers was successful Extrapolation of the aerosol concentration sampler data to termination of the sodıum spray produced an estımated maxımum concentratıon of $42 \mu \mathrm{g} / \mathrm{cm}^{3}$ Test duration was $24 \mathrm{~h}$

\subsection{Sodium Oxide Test 108}

The purpose of this test was to study the behavior of a low-concentration sodium oxide aerosol under dry atmospheric conditions This test completed the series of tests on sodium oxide aerosols produced by pool fires Earlier tests in this series have been reported previously ${ }^{1}$ The aerosol was generated by a sodium pool fire of $045 \mathrm{~kg}$ ( $1 \mathrm{lb}$ ) of heated sodium metal which persisted for approximately 2 to $25 \mathrm{~min}$ The initial vessel atmosphere was air at a relative humidity of $<20 \%$, and the initial pressure and temperatures were slightly above ambient because of the preheatıng of the sodium burn pan and delivery lines A maximum aerosol concentration of $2 \mu \mathrm{g} / \mathrm{cm}^{3}$ was measured at 10 min after initiation of the pool fire Test duration was $48 \mathrm{~h}$ 


\subsection{Uranium Oxide Test 204}

This test was the first of a series to study the behavior of a uranium oxide aerosol at concentrations higher than those produced with the dc arc generator. The first attempt to perform Test 204 with the newly installed plasma torch generator failed due to clogging of the very fine uranium metal powder in the powder feed system supplying the plasma torch. Modifications were then made to the powder feed system and a second attempt was made. This second attempt was more successful even though some powder clogging was again encountered. The generator was operated for $20 \mathrm{~min}$ although most of the aerosol production occurred in the first $7 \mathrm{~min}$. The first measured aerosol mass concentration at $4 \mathrm{~min}$ after termination of generator operation was $0.7 \mu \mathrm{g} / \mathrm{cm}^{3}$. Test duration was $48 \mathrm{~h}$.

\subsection{Uranium Oxide Test 205}

For this test, uranium metal powder with a larger particle size was used in an effort to circumvent the powder clogging problems encountered during Test 204. Aerosol generation was terminated after 5 min because of a severe reduction in powder injection rate. An estimated $0.2 \mathrm{~kg}(0.44 \mathrm{lb})$ of uranium powder was injected into the combustion chamber during this period. Posttest examination revealed that the powder injection problem was because of uranium oxide plugging of the exits of the capillary powder feed tubes within the generator's combustion chamber. The first measured aerosol concentration at $5.5 \mathrm{~min}$ after termination of generation was $2.7 \mu \mathrm{g} / \mathrm{cm}^{3}$; extrapolation to the time of termination of generation gave an estimated maximum aerosol concentration of approximately 4 $\mu \mathrm{g} / \mathrm{cm}^{3}$. Duration of the test was $48 \mathrm{~h}$.

\subsection{Uranium Oxide Test 206}

Modifications were made to the capillary powder supply tubes of the generator before conduct of this test. The powder feeder was charged with $1 \mathrm{~kg}(2.2 \mathrm{lb})$ of uranium metal powder. All of this material was injected into the plasma torch generator during a 9.3-min period. At $5.3 \mathrm{~min}$ after termination of the generation, the aerosol concentration was measured to be $3.8 \mu \mathrm{g} / \mathrm{cm}^{3}$; extrapolation to time of termination of generation gave an estimated maximum concentration of about $5.6 \mu \mathrm{g} / \mathrm{cm}^{3}$. Test duration was $48 \mathrm{~h}$.

\subsection{Uranium Oxide Test 207}

This test differed from the previous tests in that aerosol mass samples were taken during the aerosol generating period to define the early increase in aerosol concentration. The powder feeder was charged with $2 \mathrm{~kg}(4.4 \mathrm{lb})$ of uranium metal powder. All of this material was injected into the plasma torch generator during a $26-\mathrm{min}$ period. The aerosol concentration achieved was not as large as was anticipated. Posttest examination revealed that a large quantity of uranium oxide had accumulated in the outlet of the generator. The maximum measured aerosol concentration was $3.2 \mu \mathrm{g} / \mathrm{cm}^{3}$ at $23 \mathrm{~min}$ after start of aerosol generation. Test duration was $48 \mathrm{~h}$. 


\section{RESULTS FROM INDIVIDUAL AEROSOL TESTS}

The results from each test are summarized in tables and graphs in this section. At the beginning of each section, a table is presented listing test parameters, parameters measured, and a summary of test results. Following each of these initial tables are graphs and numbered tables reporting aerosol mass concentrations, fallout and plateout rates, cumulative mass fallout and plateout, aerosol particle size, vessel pressure, vessel atmosphere temperatures, and temperature gradients near the vessel wall as functions of time. Time is measured from the start of aerosol generation. To aid in interpretation of these graphs and tables, the following comments are offered.

Mass concentration. Results for all seven mass concentration filter samplers are presented in one graph for Tests 108 and 204-207. For Tests 106 and 107, only results from operable samplers are presented. Values of mass concentrations for $\mathrm{U}_{3} \mathrm{O}_{8}$ or $\mathrm{Na}_{2} \mathrm{O}$ within the vessel atmosphere are computed under vessel atmospheric conditions existing at the time of the sample. The legend on the graphs lists the elevation and the radial distance from centerline for all samplers. The radial direction of each sampler is given in Table 1.

Aerosol fallout and plateout rates; cumulative values for fallout and plateout mass. The data reported in these graphs were obtained from the coupon samplers. An average fallout or plateout rate was computed from the mass of aerosol deposited on the coupon during the exposure period. The sample time is taken as one-half the exposure period added to the time at the start of the sample.

Values for cumulative mass fallout or plateout were computed by multiplying the fallout and plateout rate by the time of exposure of the coupon and the appropriate area within the vessel.

Aerosol particle size. The data presented were derived with an Andersen Mark III Particle Sizing Stack Sampler (cascade impactor). The raw data were processed to the extent necessary to produce the tables included in this report.

Vessel gas pressure. For all the tests, the initial gas pressure was at mospheric (0 psig). During Tests 106-108, the primary pressure rise was produced by burning the sodium. During Tests 204-207, a slight initial pressure rise was produced by heat from the plasma torch generator and the heated burn pan used to maintain convection currents. However, the second pressure rise in Tests 204-207, noted after about $3000 \mathrm{~s}$, is due to the heat from the burn pan. The graphs depict gas pressure as a function of time after start of aerosol generation, except in the case of Test 108, where time starts at $47 \mathrm{~s}$ after start of aerosol generation.

Vessel gas temperatures. Three graphs are presented displaying the temperatures within each of the four quadrants at three different elevations. The legend on each graph gives the elevation measured from the vessel midplane and the radial distance from the centerline of the vessel. An elevation of +1.5 $\mathrm{m}$ from midplane is $4.27 \mathrm{~m}$ ( $14 \mathrm{ft}$ ) from the bot tom of the vessel; the elevation at midplane is $2.74 \mathrm{~m}(9 \mathrm{ft}$ ),

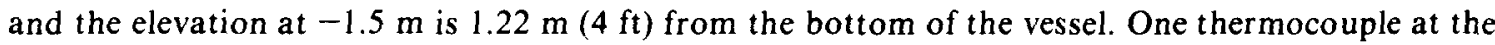
+1.5 -m level (TE 4-7) is near the exit from the plasma torch aerosol generator and senses the heat of the plasma flame; consequently during uranium oxide aerosol generation, this thermocouple indicates a temperature higher than others located at this elevation. Also, for Test 108, time begins at $47 \mathrm{~s}$ after start of sodium pool fire.

Temperature gradient at vessel wall. Two graphs are presented to illustrate the temperature gradients near the vessel wall on the north radius $(-1.5 \mathrm{~m}$ from midplane of the vessel) and on the east radius at the centerline. Two thermocouples measure the temperature on both the outside and inside vessel wall; four other thermocouples measure temperatures at varying distances from the inside wall. 
Three additional graphs are also presented. Two of these graphs display the temperatures at various distances from the wall at selected values of time from start of aerosol generation. A third graph illustrates the magnitude of the temperature gradient (degrees Celsius per centimeter) at the two thermocouple rake locations as a function of time. For runs 106 and 107, a large negative temperature gradient may be noted at the -1.5 -m elevation; this was caused by the impact of burning sodium on the vessel wall near the thermocouple array which produces a wall temperature higher than that of the nearby vessel atmosphere. This value is computed by subtracting the wall temperature from the atmosphere temperature measured by the thermocouple at $0.125 \mathrm{~cm}$ and then dividing the result by $0.125 \mathrm{~cm}$.

Posttest results. In this section, the total aerosol mass concentration achieved is listed. This value is either measured at, or extrapolated to the time of termination of aerosol generation. The final aerosol distribution (percent) at the end of the test is calculated from the total mass fallout and plateout as determined by the total fallout and plateout samplers; the mass of airborne aerosol is measured by the final filter samplers taken just prior to termination. 
4.1 Summary and Uath Curaphs for it ast 160

\section{Aerosol source}

Test aerosol used

Ma 0

Aerosol gererus:

Duration of aeresnl generat.

$$
\text { is ray fi, }
$$

inir

\section{Vessel atmosphere prior to aerusol generation}

Oxygen leve!

Relative humıdity

Temperature

Pressure

2018

A $\cdots,$.

tanto :

\section{Duration of test operations}

$$
24 \pi
$$

Aerosol parameters measured and figure number

Mass concentration of atrosol

$\operatorname{lig} 2$

Aerosol fallout rate

tig

Aerosol plateout rate

5 is 4

Cumulative mass fallout and plateous

Aerosol particle size

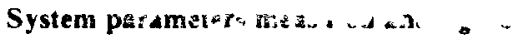

Vessel atmosphere pressure

$F: g$

Vessel atmosphere temperatures

, $7 y$

Thermal gradients at vessel wall

\section{Posttest results}

Maximum aerosol cur ardies a

Acrosol disurbutiona od ntest

Stull suspended in vesse! atmosphere

Plated onto internal, ia .

Settied onto versel froor

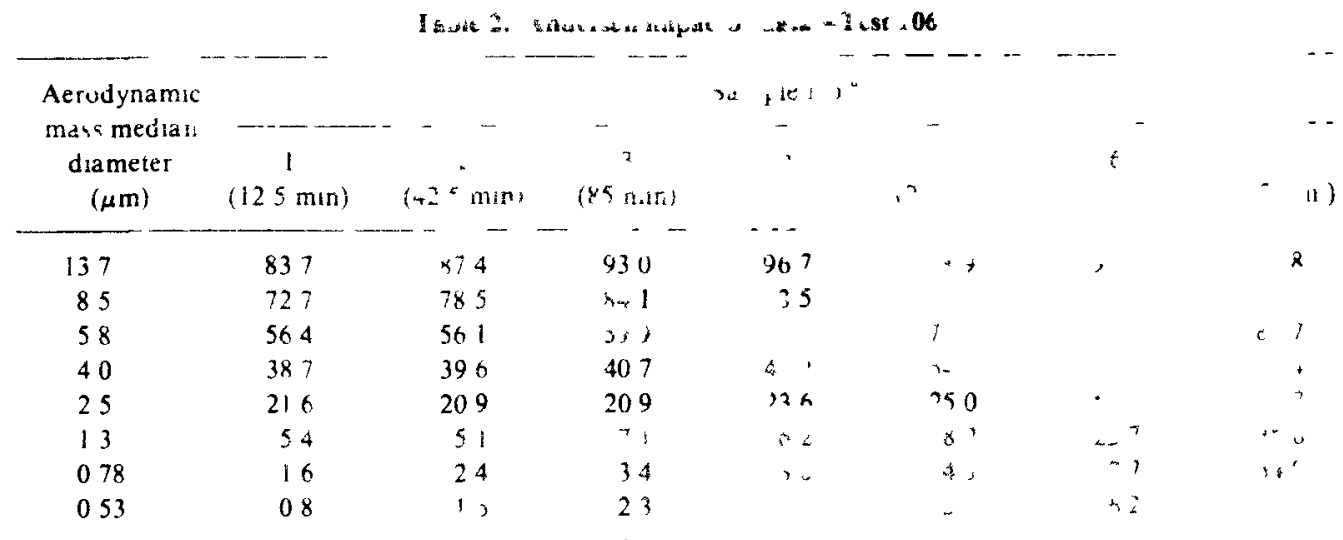

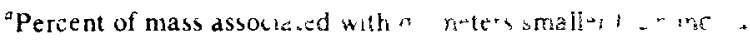


ORNL-DWG 80-5724 ETD

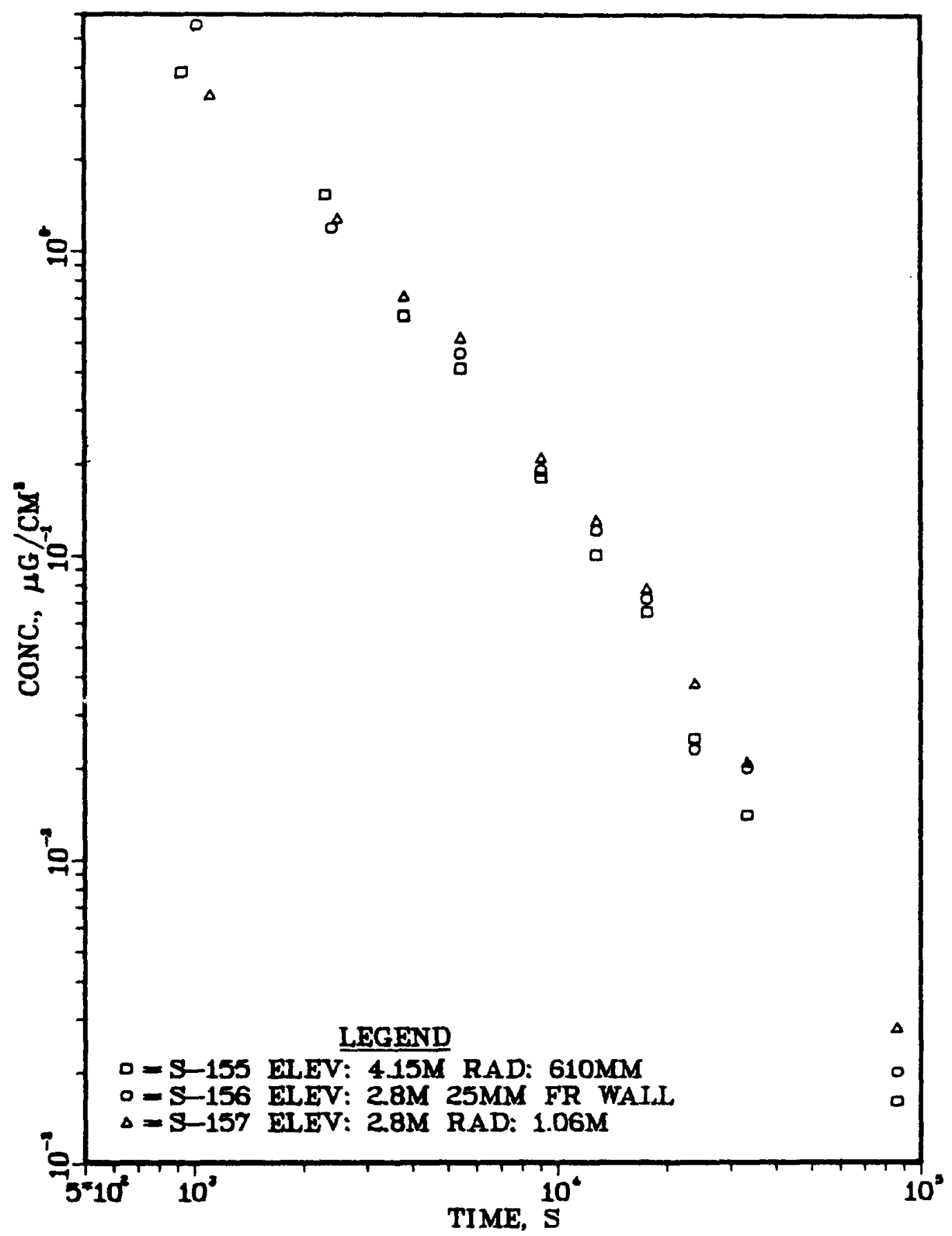

Fig. 2. Aerosol mass concentrations (measured with three samplers) vs time-NSPP Test 106. 


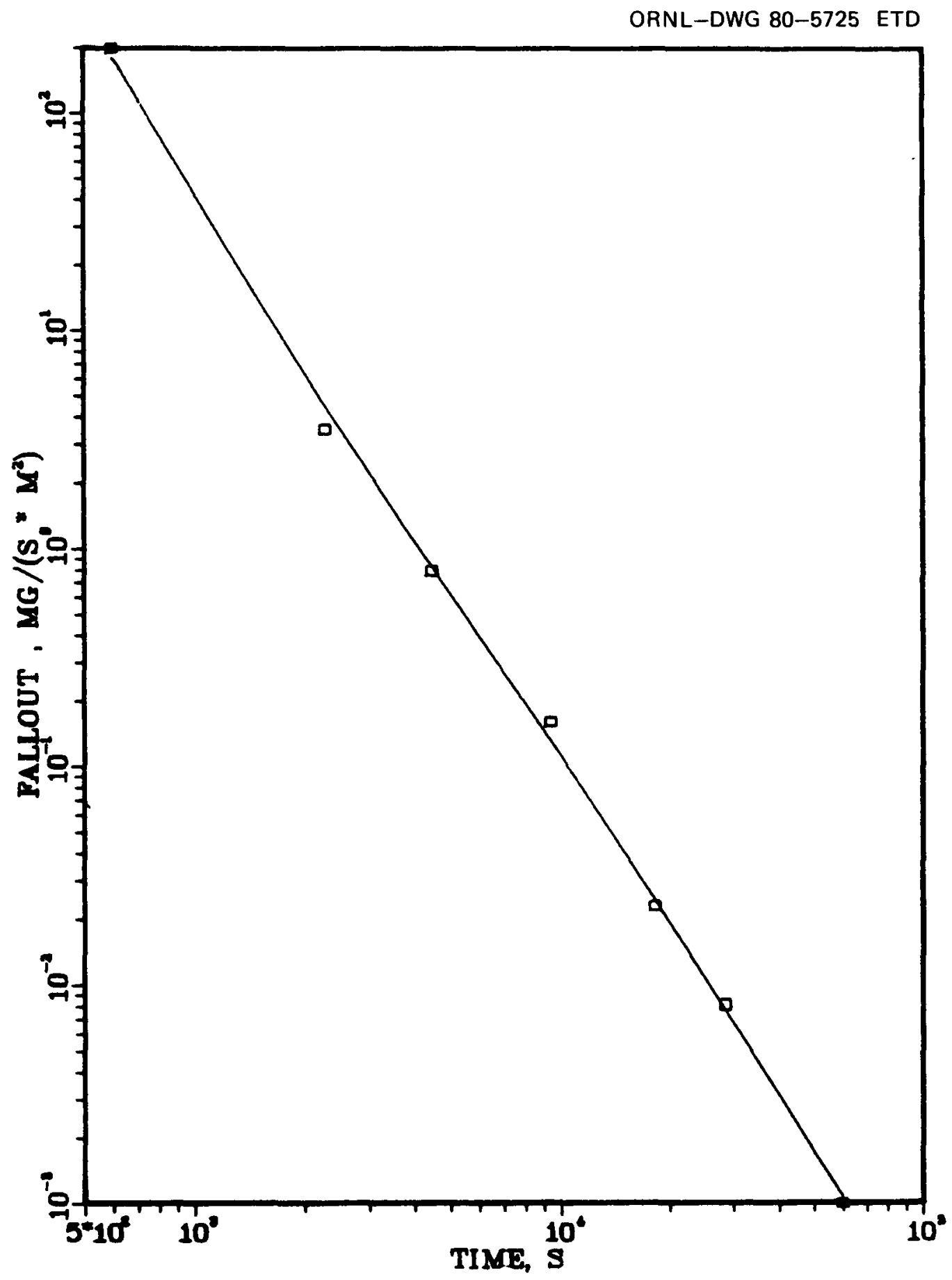

Fig. 3. Fallout rate vs time-NSPP Test 106. 


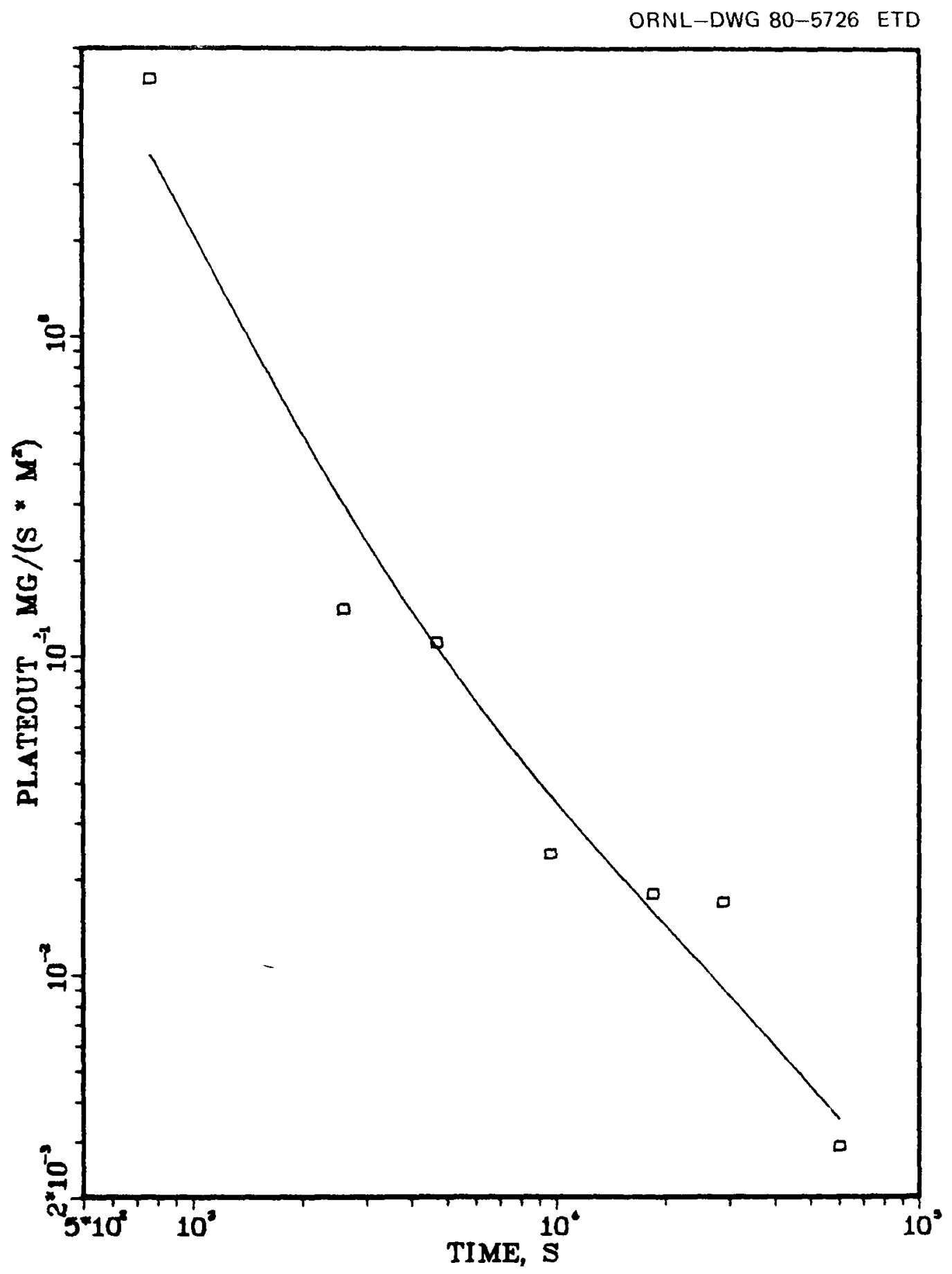

Fig. 4. Plateout rate vs time-NSPP Test 106. 


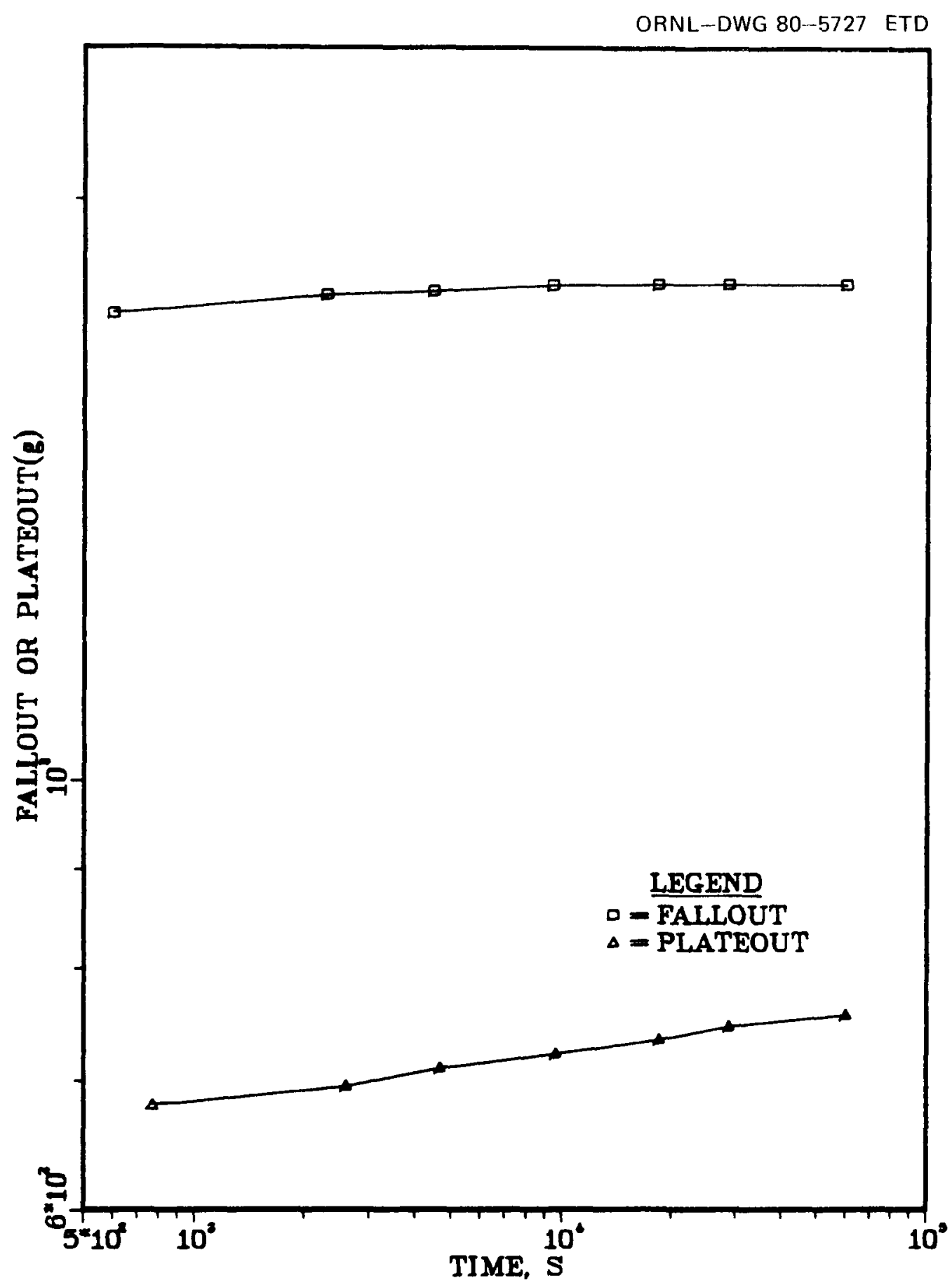

Fig. 5. Cumulative fallout and plateout mass vs time-NSPP Test 106. 


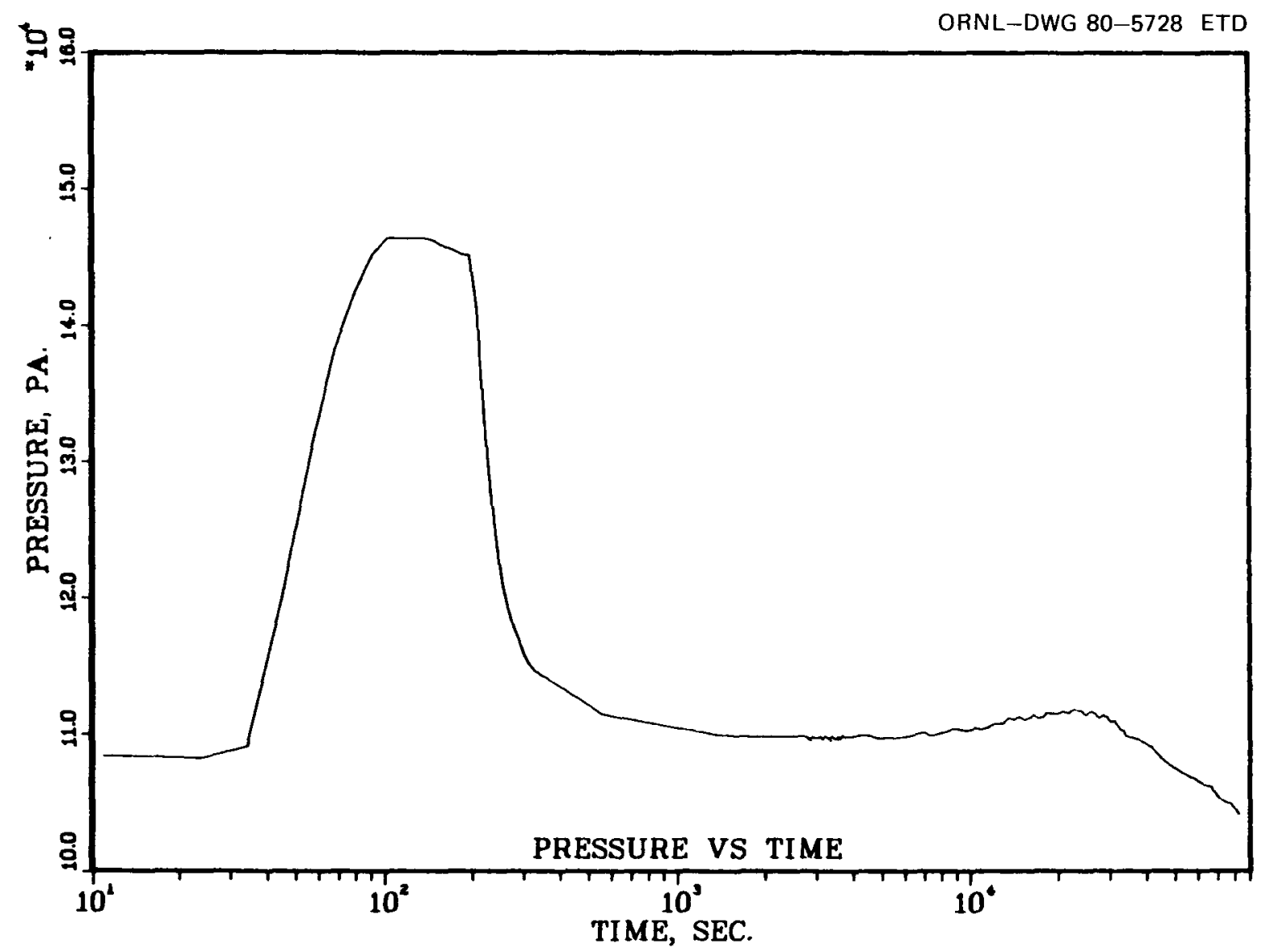

Fig. 6. In-vessel pressure vs time-NSPP Test 106. 


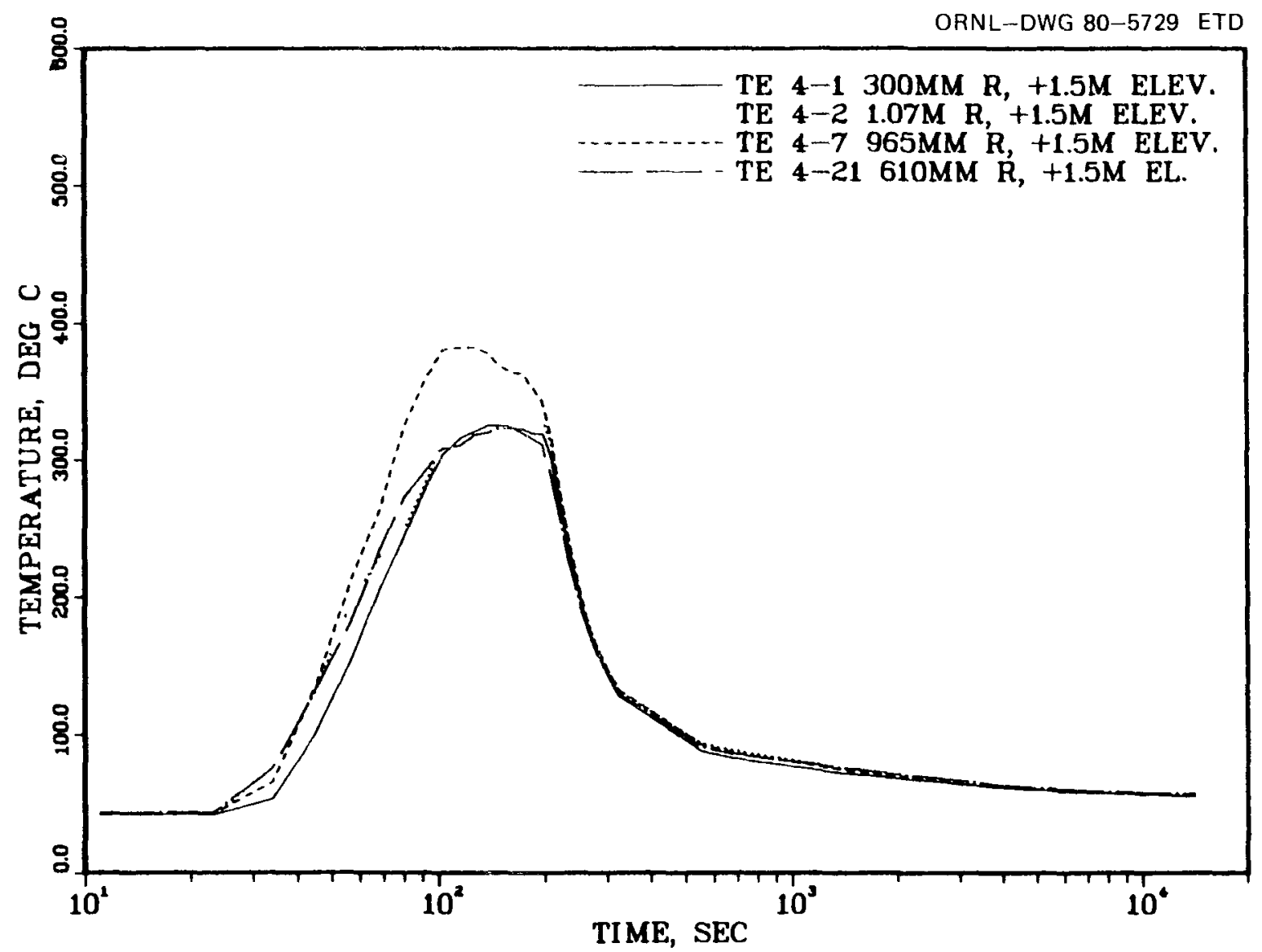

Fig. 7. Temperature measurements at $1.5 \mathrm{~m}$ above vessel midplane-NSPP Test 106. 


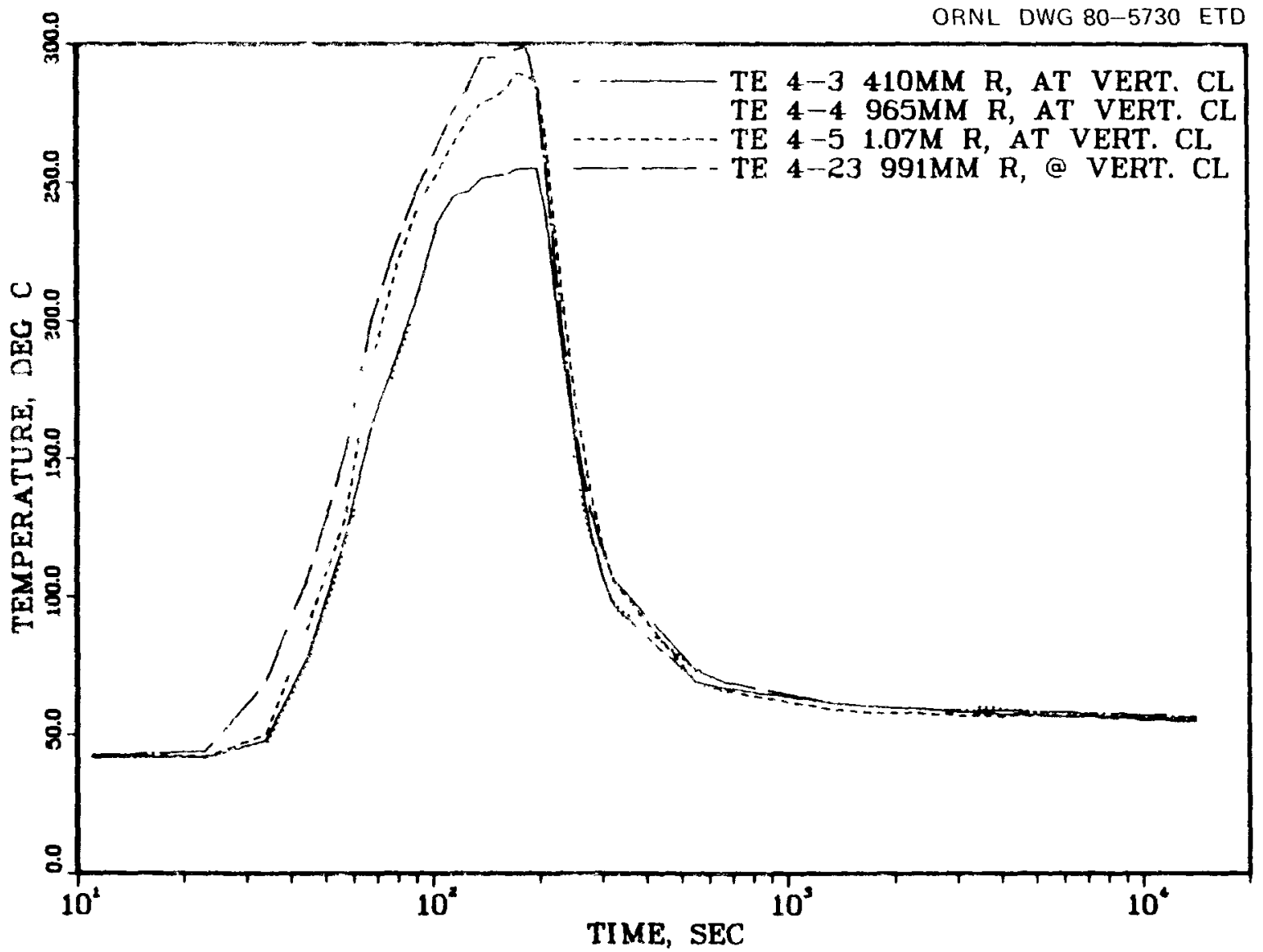

Fig. 8. Temperature measurements at vessel midplane-NSPP Test 106. 


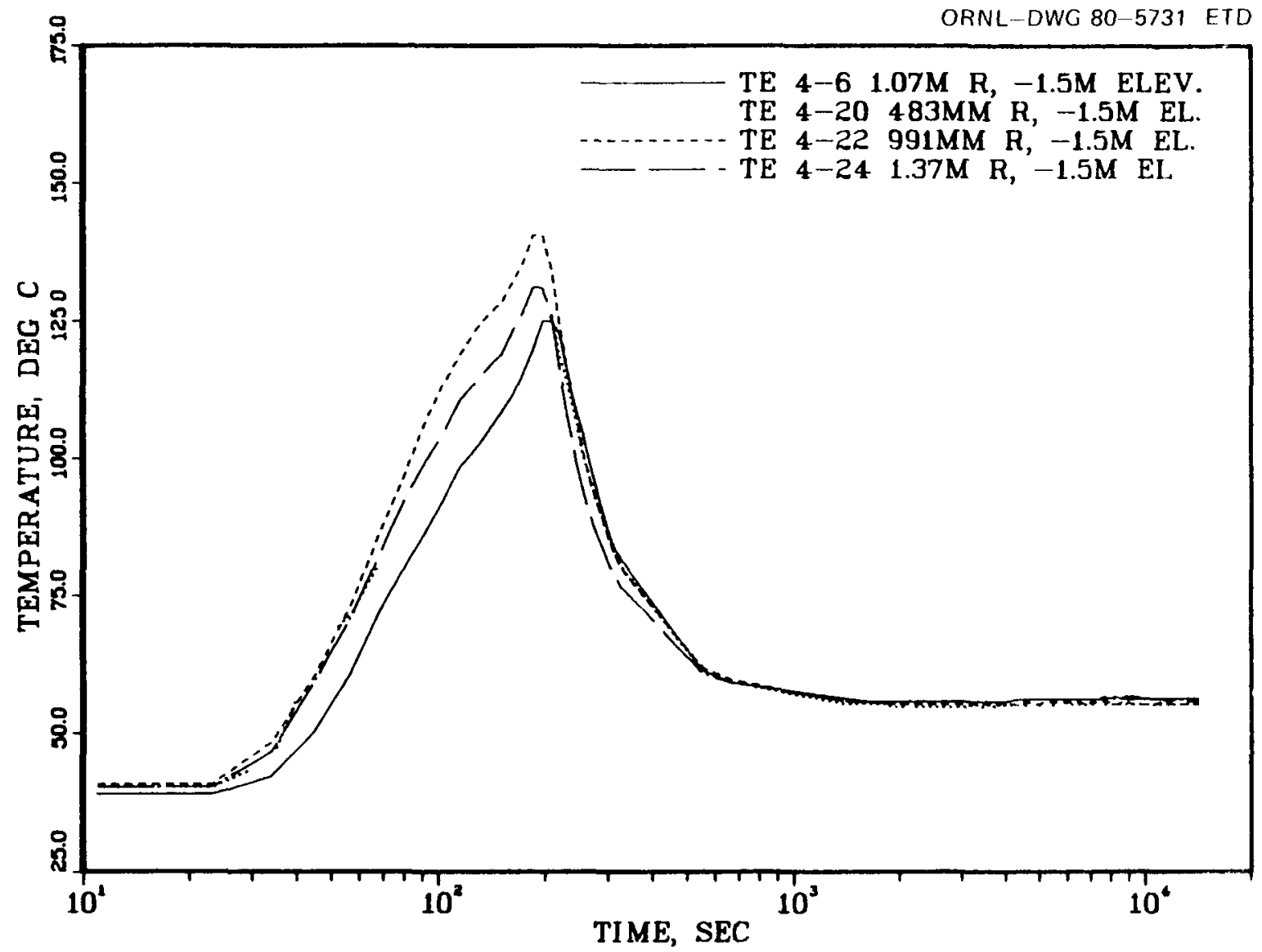

Fig. 9. Temperature measurements at $1.5 \mathrm{~m}$ below vessel midplane-NSPP Test 106. 


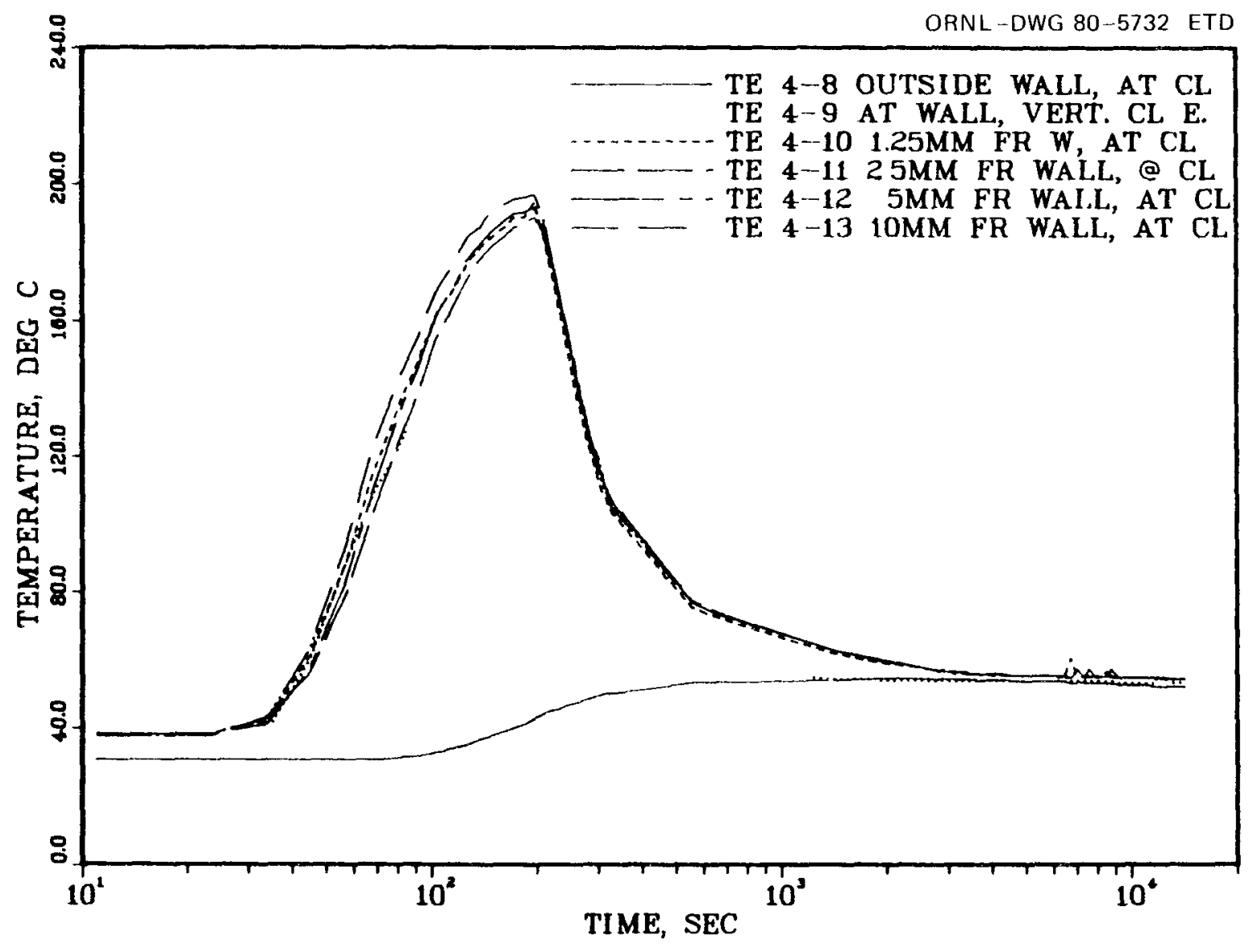

Fig. 10. Temperature measurements near the vessel wall at vessel midplane-NSPP Test 106. 


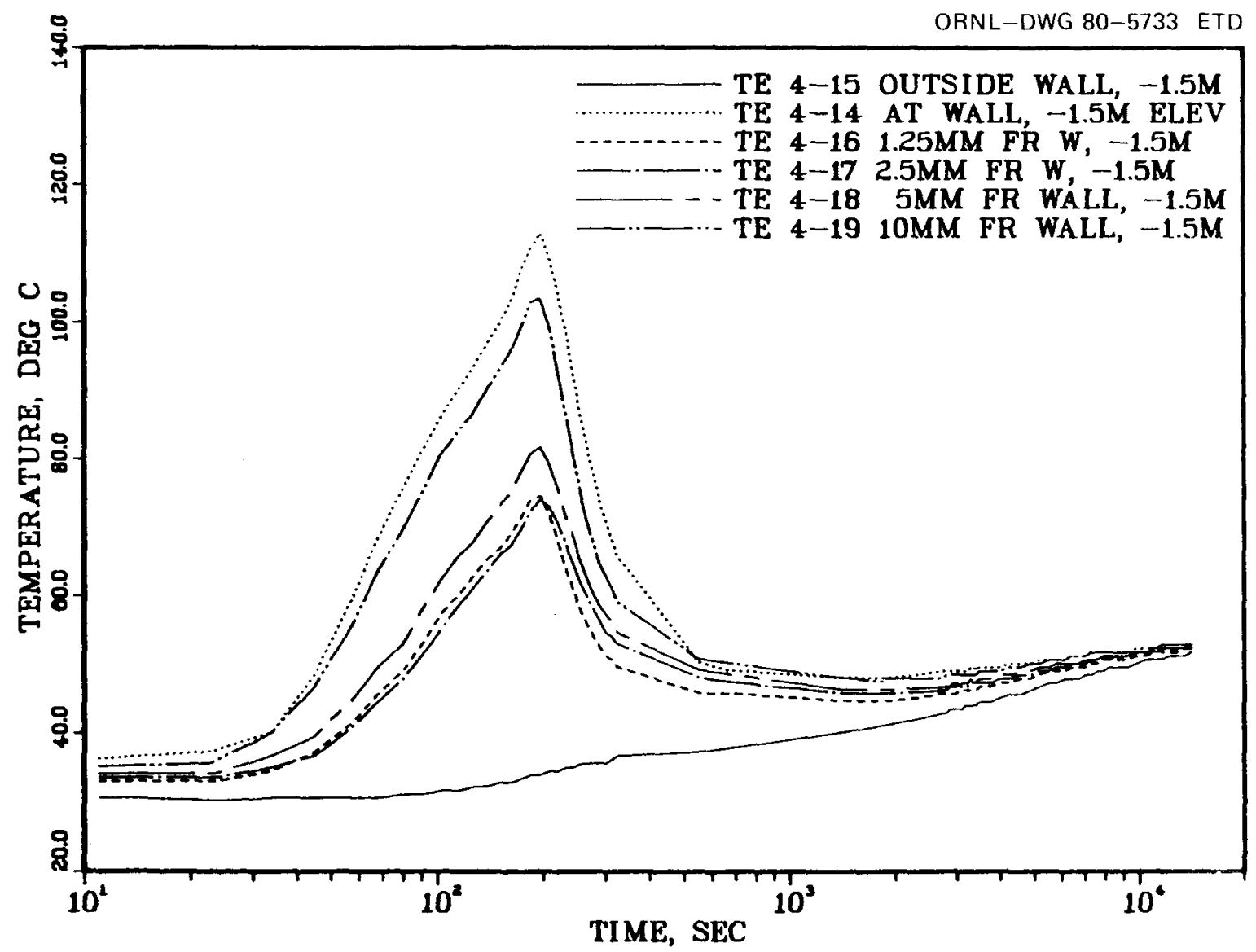

Fig. 11. Temperature measurements near the vessel wall at $1.5 \mathrm{~m}$ below vessel midplane-NSPP Test 106. 


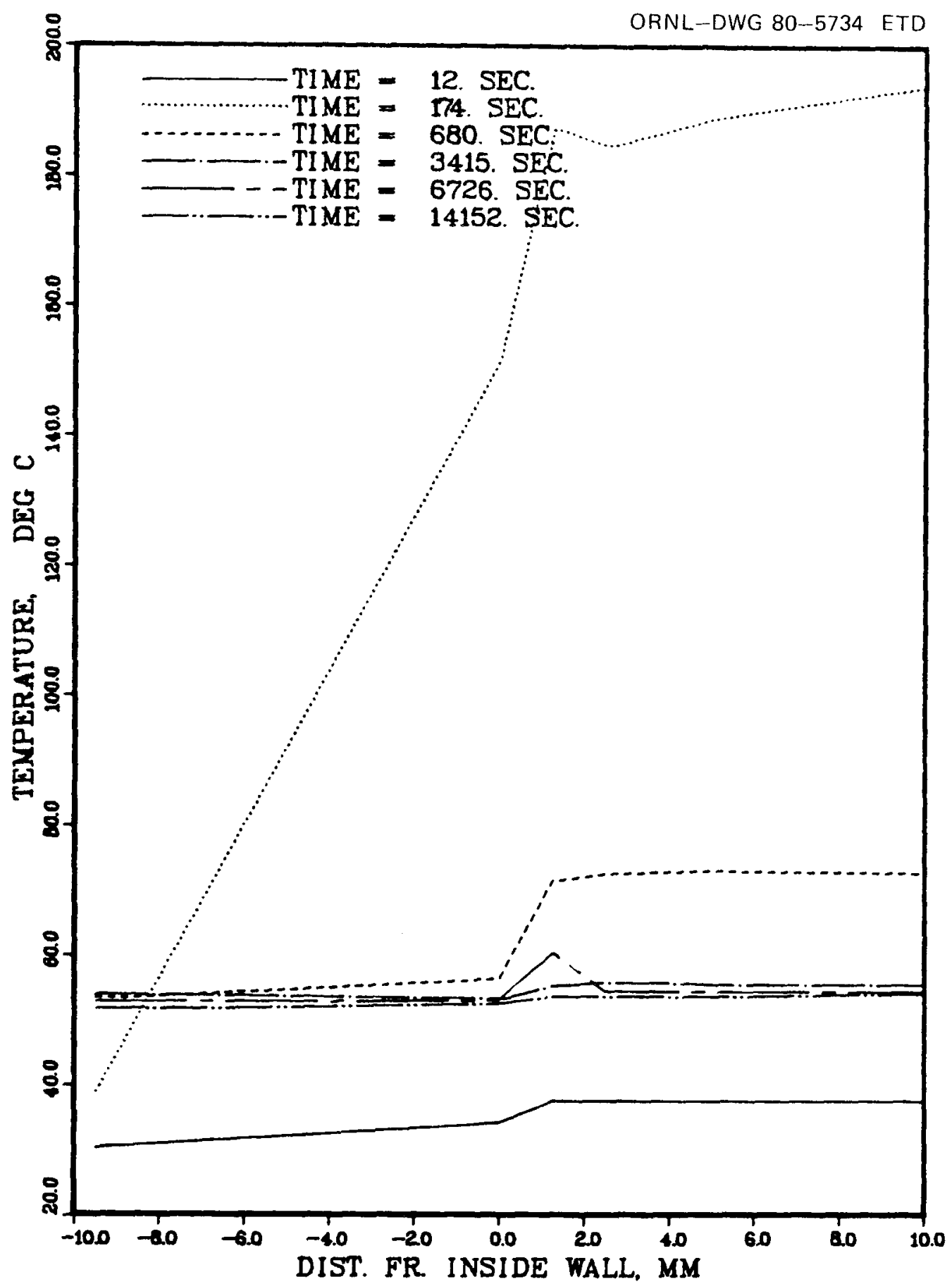

Fig. 12. Temperature profile near the vessel wall at mid plane for various times after start of aerosol generation (note that the distance is measured from the inside wall toward the center of the vessel)-NSPP Test 106. 


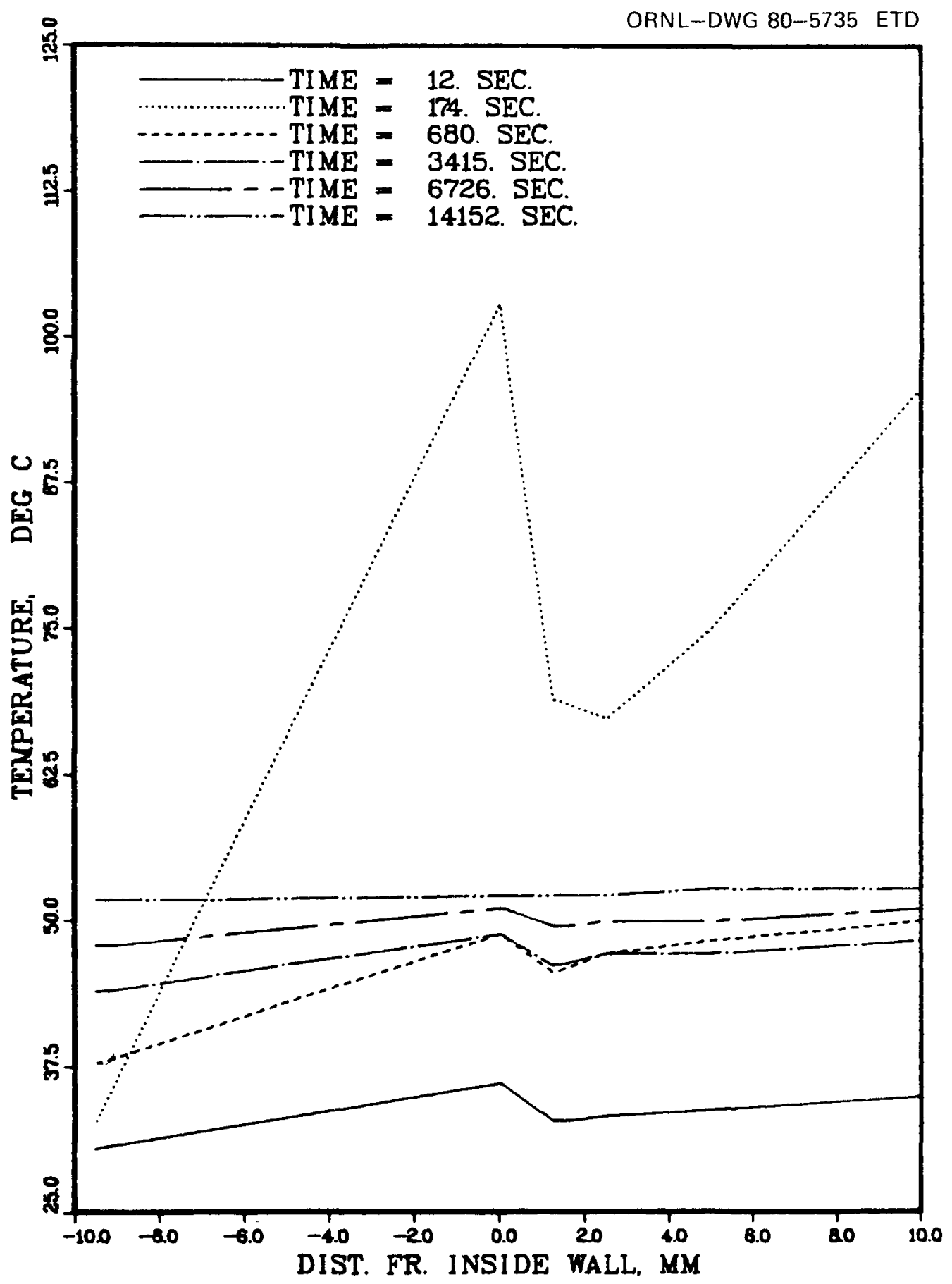

Fig. 13. Temperature profile near the vessel wall at $1.5 \mathrm{~m}$ below midplane for various times after start of aerosol generation-NSPP Test 106. 


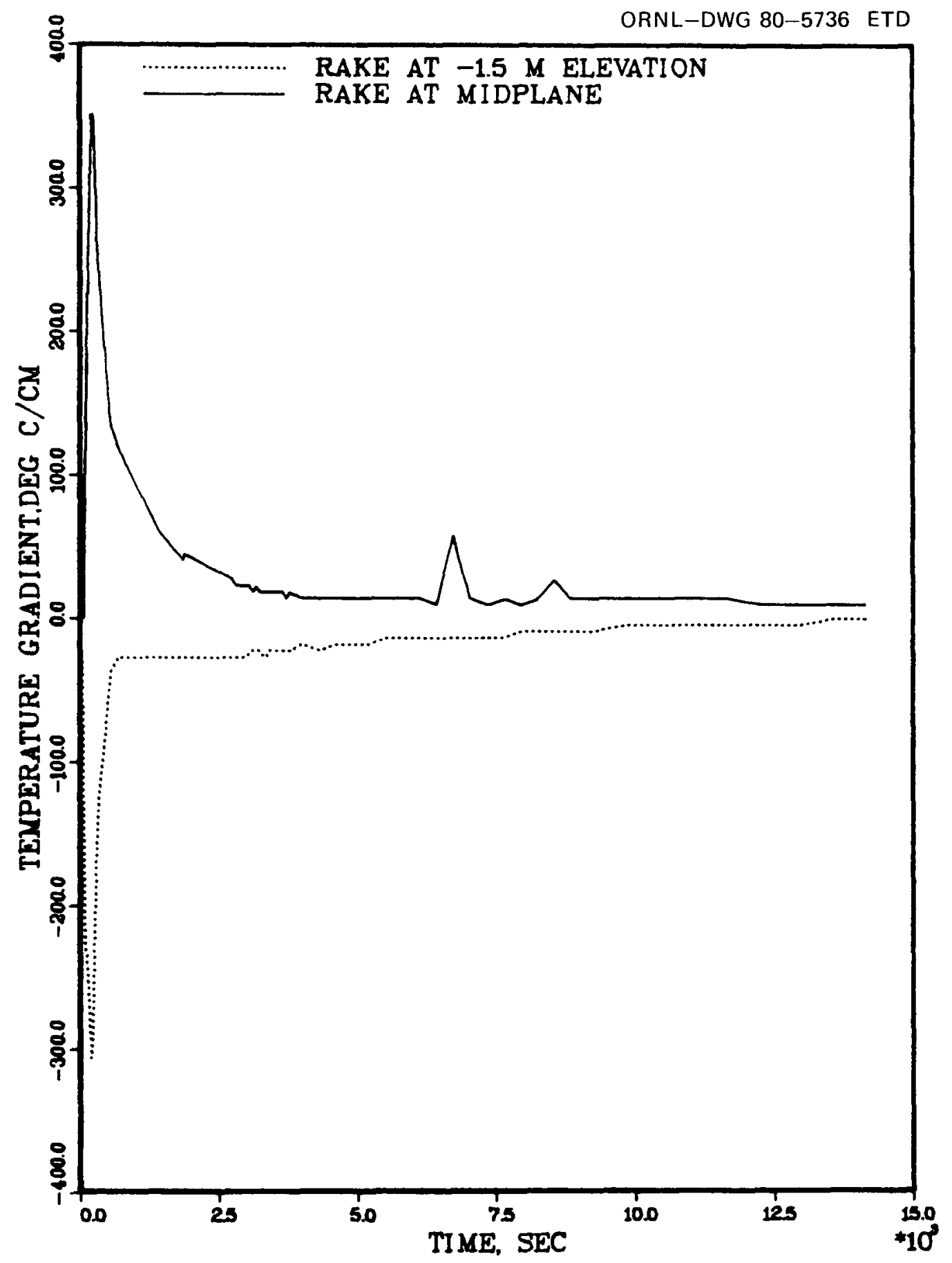

Fig. 14. Temperature gradient at the vessel wall for two elevations-NSPP Test 106. 


\subsection{Summary and Data Graphs for Test 107}

\section{Aerosol source}

Test aerosol used

$\mathrm{Na}_{2} \mathrm{O}$

Aerosol generator

Duration of aerosol generation

Spray fire

$65 \mathrm{~min}$

Vessel atmosphere prior to aerosol generation

Oxygen level

$21 \%$

Relative humidity

$<20 \%$

Temperature

Ambient

Pressure

Ambient

\section{Duration of test operations}

$24 \mathrm{~h}$

\section{Aerosol parameters measured and figure number}

Mass concentration of aerosol

Fig 15

Aerosol fallout rate

Fig 16

Aerosol plateout rate

Fig 17

Cumulative mass fallout and plateout

Fig 18

Aerosol particle size

Table 3

\section{System parameters measured and figure number}

Vessel atmosphere pressure

Fig 19

Vessel atmosphere temperatures

Figs $20-22$

Thermal gradients at vessel wall

Figs 23-27

\section{Posttest results}

Maxımum aerosol concentration achieved

$42 \mu \mathrm{g}, \mathrm{cm}^{3}$

Aerosol distribution at end of test

Still suspended in vessel atmosphere

$0001 \%$

Plated onto internal surfaces

$363 \%$

Settled onto vessel floor

$637 \%$

Table 3. Andersen impactor data - Test 107

\begin{tabular}{|c|c|c|c|c|c|c|c|}
\hline \multirow{2}{*}{$\begin{array}{l}\text { Aerodynamic } \\
\text { mass median } \\
\text { diameter } \\
(\mu \mathrm{m})\end{array}$} & \multicolumn{7}{|c|}{ Sample No ${ }^{a}$} \\
\hline & $\begin{array}{c}1 \\
(127 \mathrm{~min})\end{array}$ & $\begin{array}{c}2 \\
(30 \mathrm{~min})\end{array}$ & $\begin{array}{c}3 \\
(75 \mathrm{~m} / \mathrm{n})\end{array}$ & $\begin{array}{c}4 \\
(145 \mathrm{~min})\end{array}$ & $\begin{array}{c}5 \\
(226 \mathrm{~min})\end{array}$ & $\begin{array}{c}6 \\
(380 \mathrm{~min})\end{array}$ & $\begin{array}{c}7 \\
(558 \mathrm{~m} / \mathrm{n})\end{array}$ \\
\hline 137 & 969 & 819 & 886 & 968 & 993 & 994 & 988 \\
\hline 85 & 911 & 698 & 806 & 922 & 965 & 982 & 978 \\
\hline 58 & 687 & 509 & 594 & 698 & 801 & 867 & 937 \\
\hline 40 & 497 & 362 & 426 & 490 & 604 & 688 & 796 \\
\hline 25 & 266 & 213 & 244 & 266 & 352 & 412 & 448 \\
\hline 13 & 102 & 82 & 120 & 143 & 215 & 221 & 76 \\
\hline 078 & 42 & 42 & 82 & 120 & 190 & 191 & 15 \\
\hline 053 & 33 & 38 & 76 & 116 & 186 & 160 & 0 \\
\hline
\end{tabular}

${ }^{a}$ Percent of mass associated with diameters smaller than indicated size 


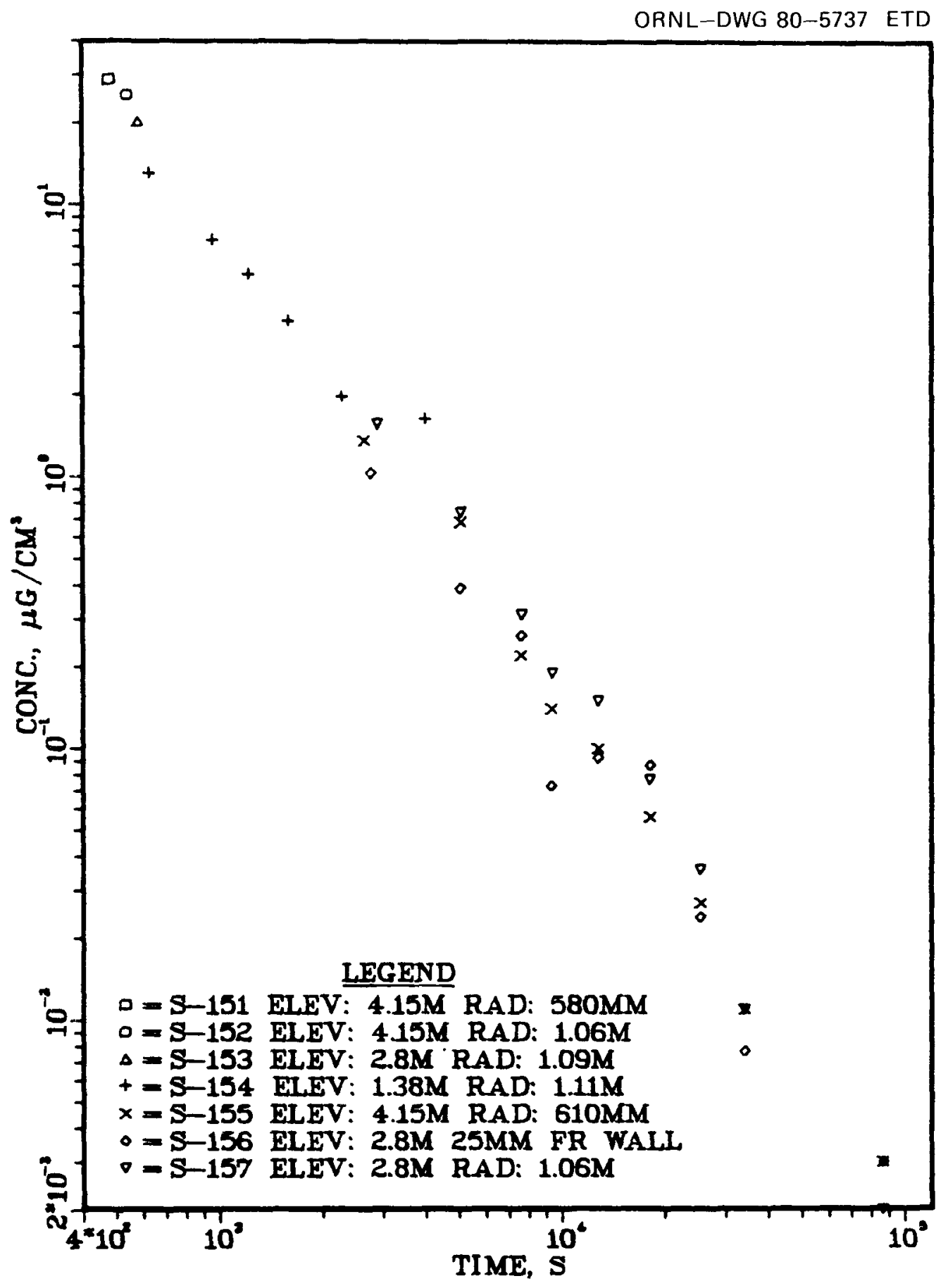

Fig. 15. Aerosol mass concentrations vs time-NSPP Test 107. 


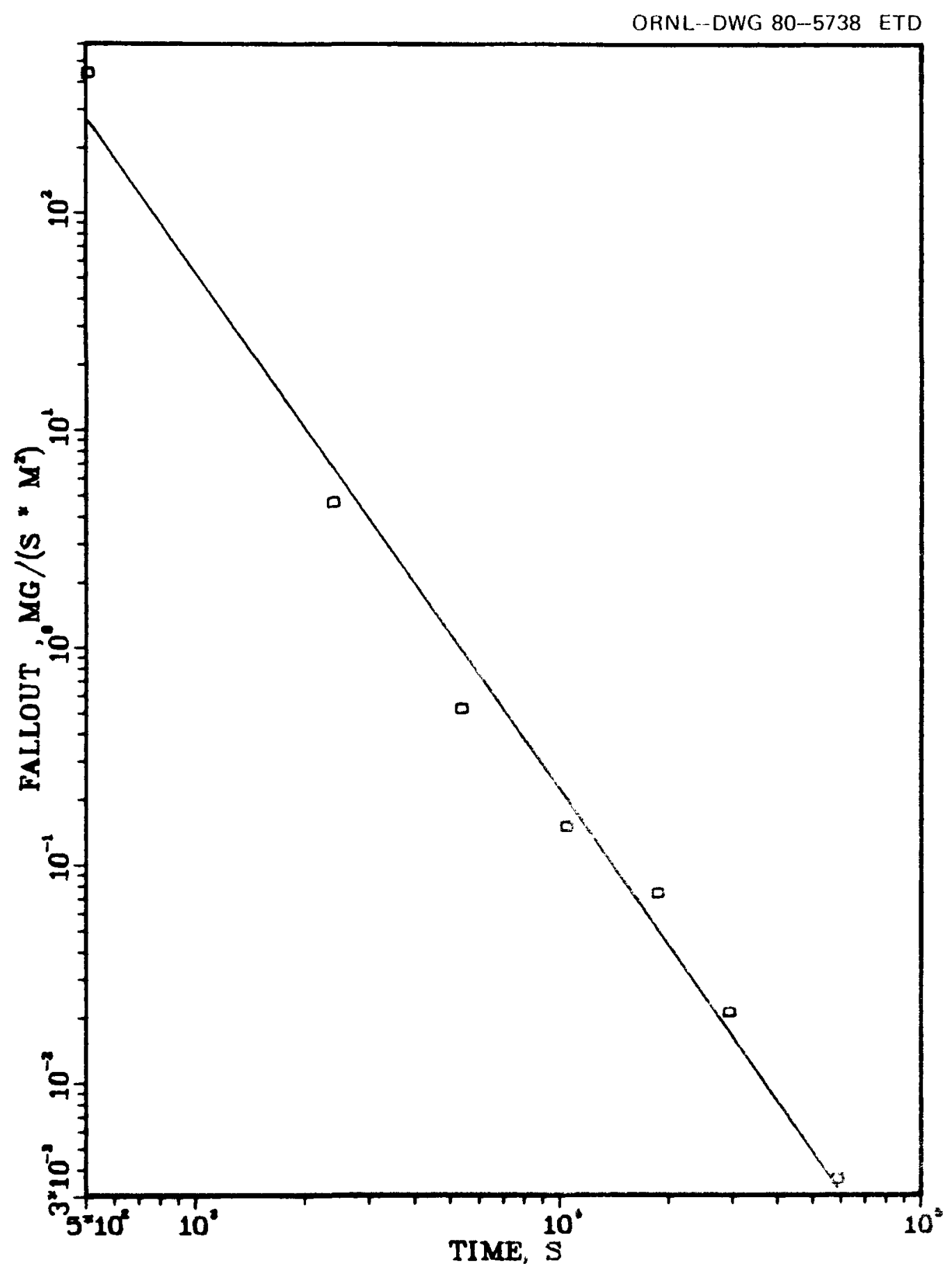

Fig. 16. Fallout rate vs time-NSPP Test 107. 
28

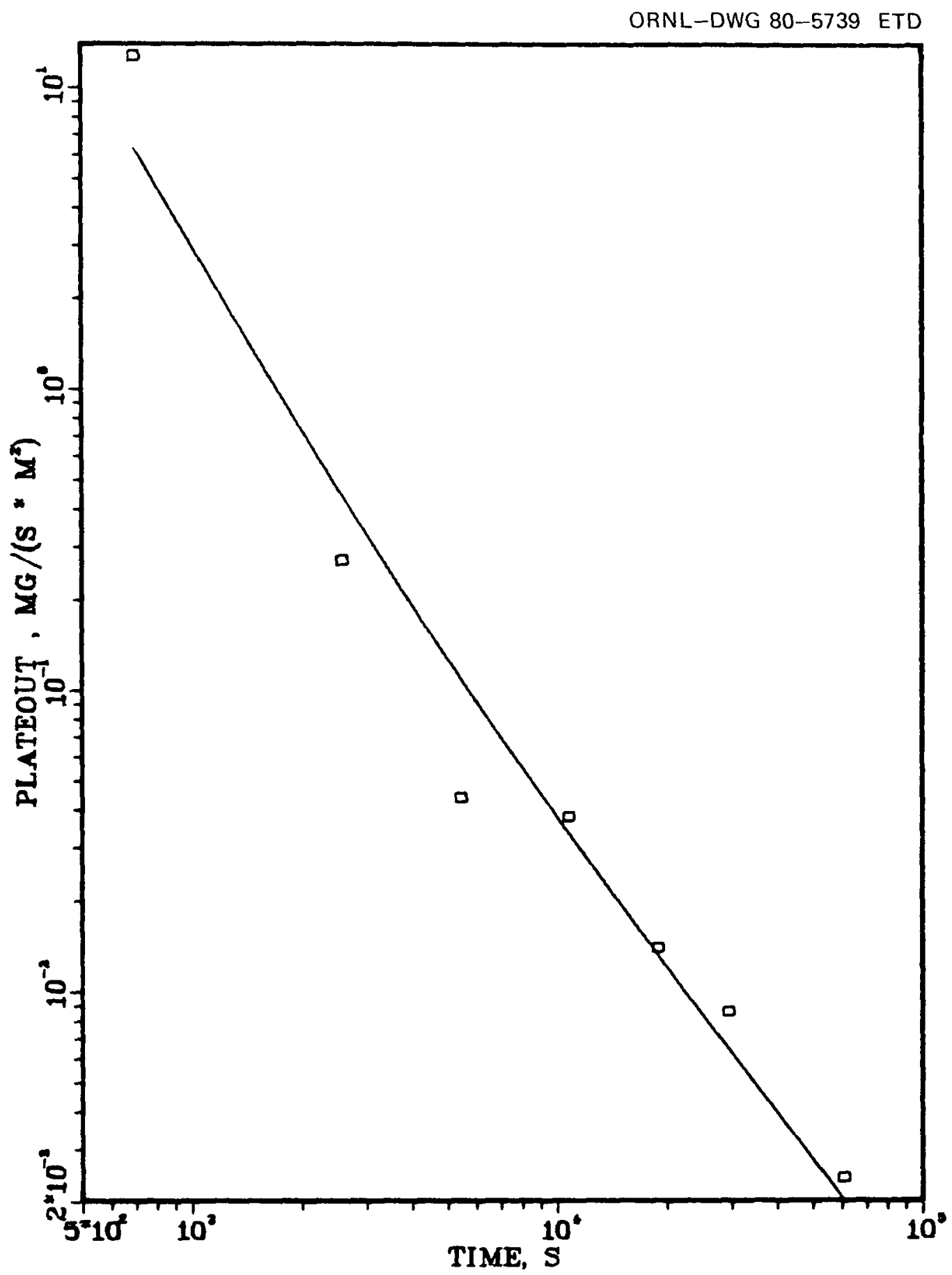

Fig. 17. Plateout rate ys time-NSPP Test 107. 


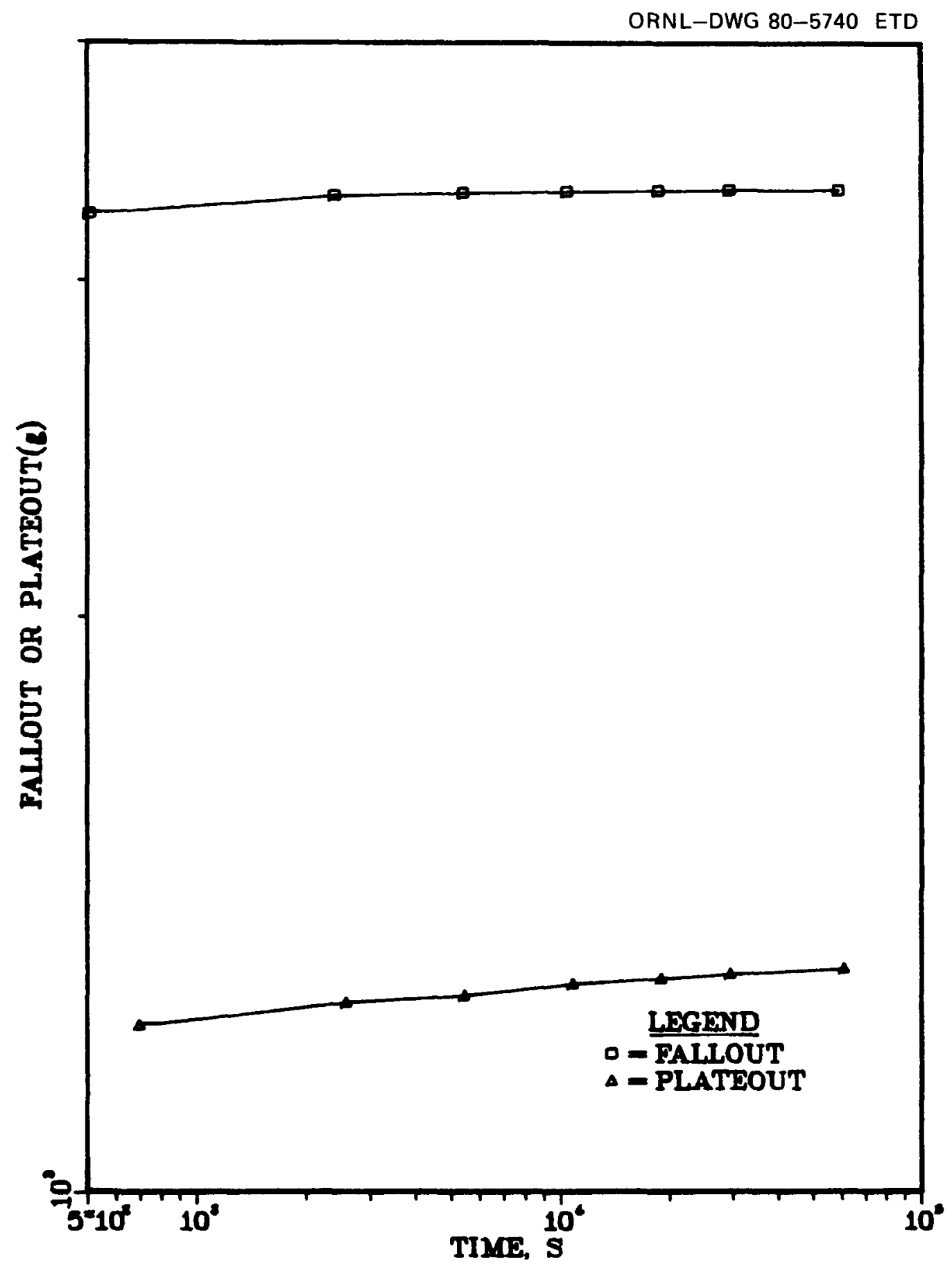

Fig. 18. Cumulative fallout and plateout mass vs time-NSPP Test 107. 
30

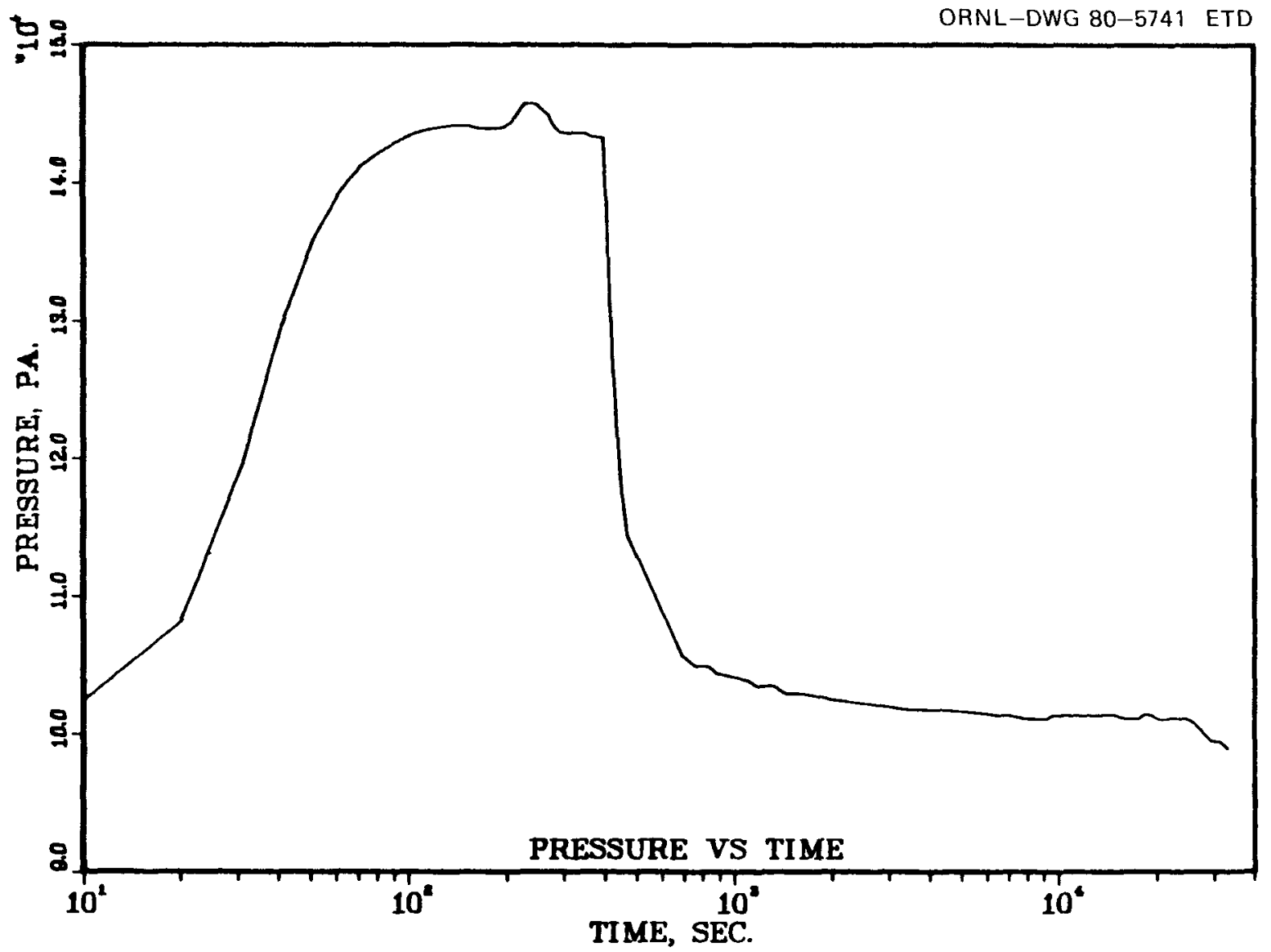

Fig. 19. In-vessel pressure vs time-NSPP Test 107. 


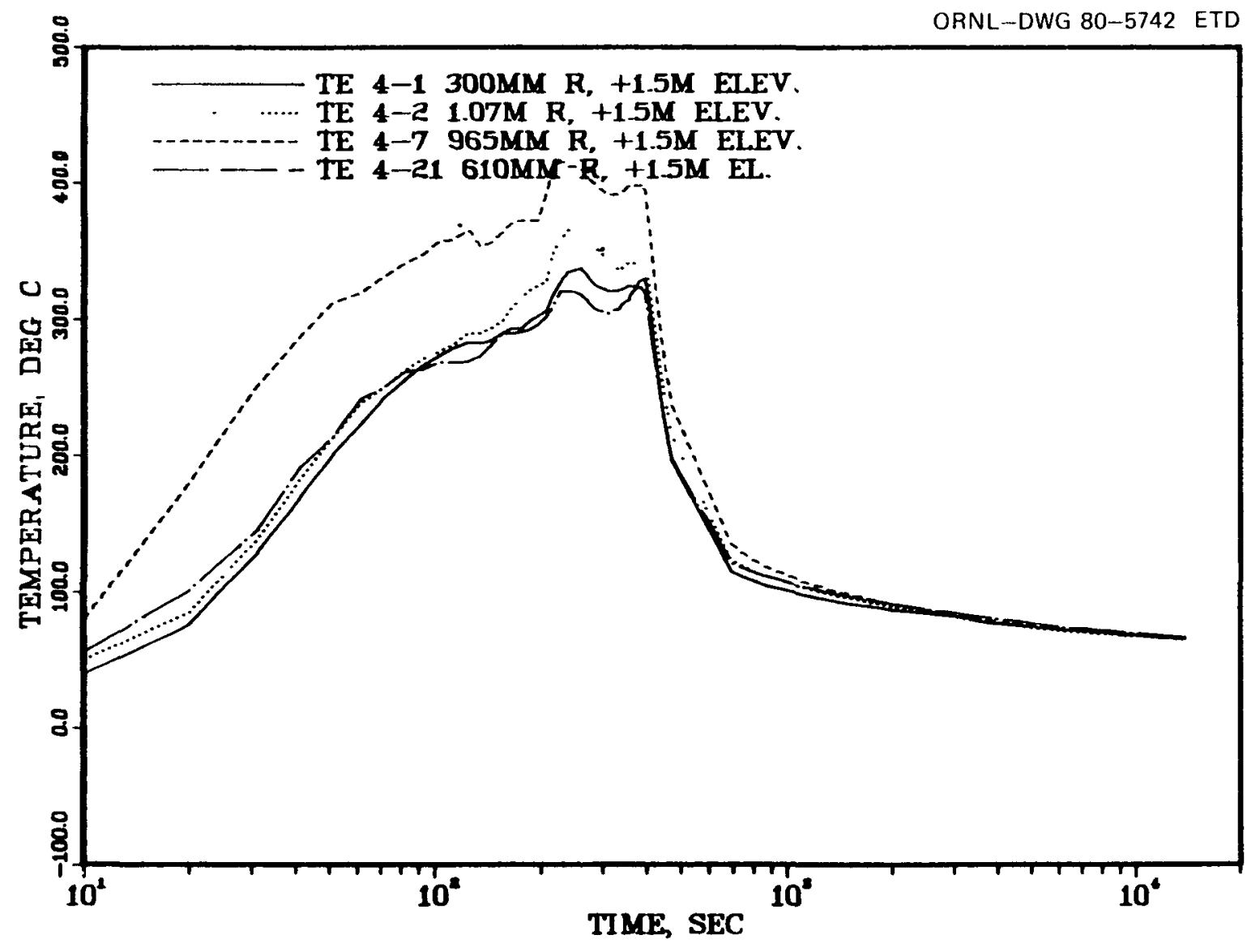

Fig. 20. Temperature measurements at $1.5 \mathrm{~m}$ above vessel midplane-NSPP Test 107. 


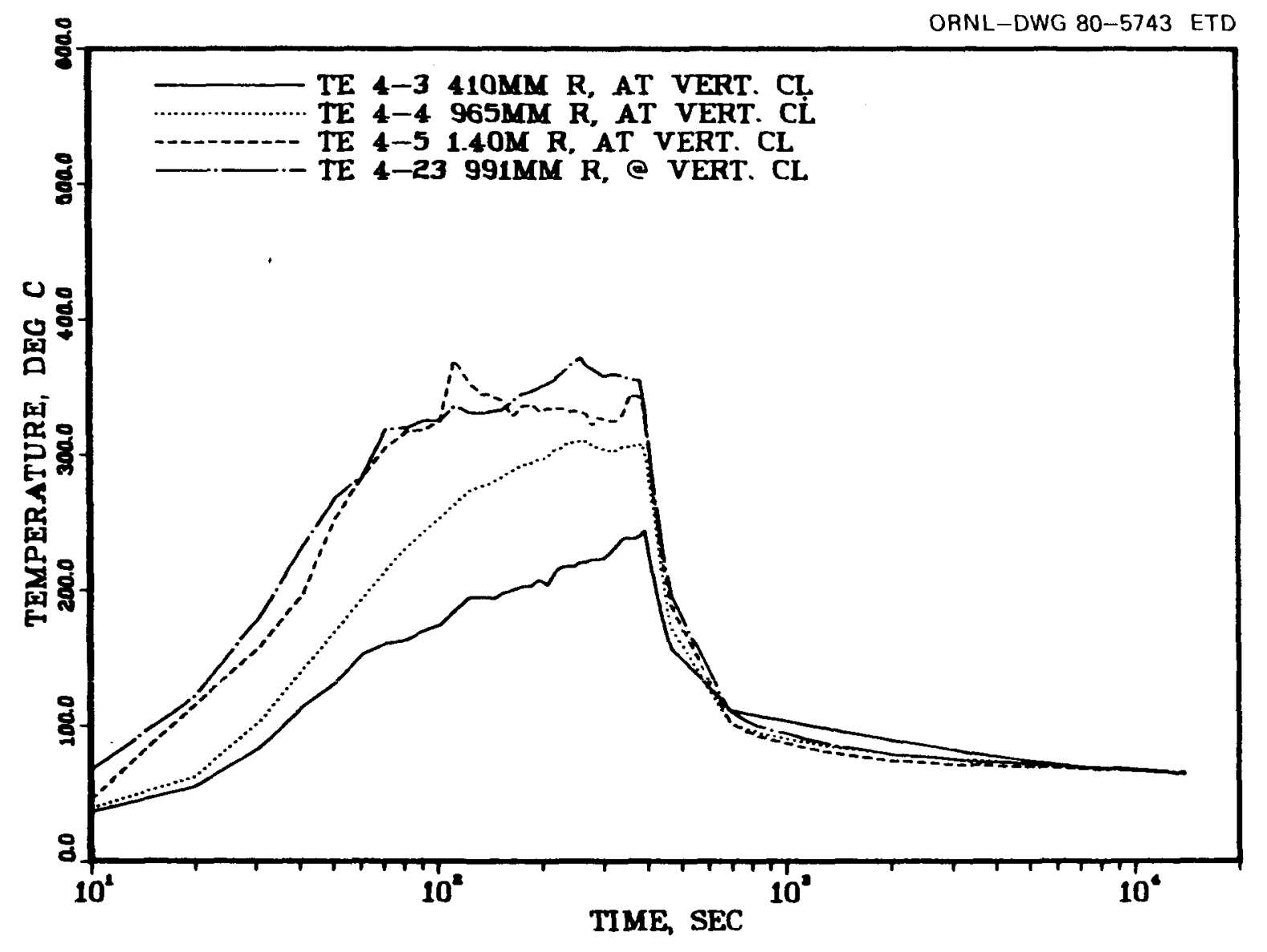

Fig. 21. Temperature measurements at vessel midplane-NSPP Test 107. 


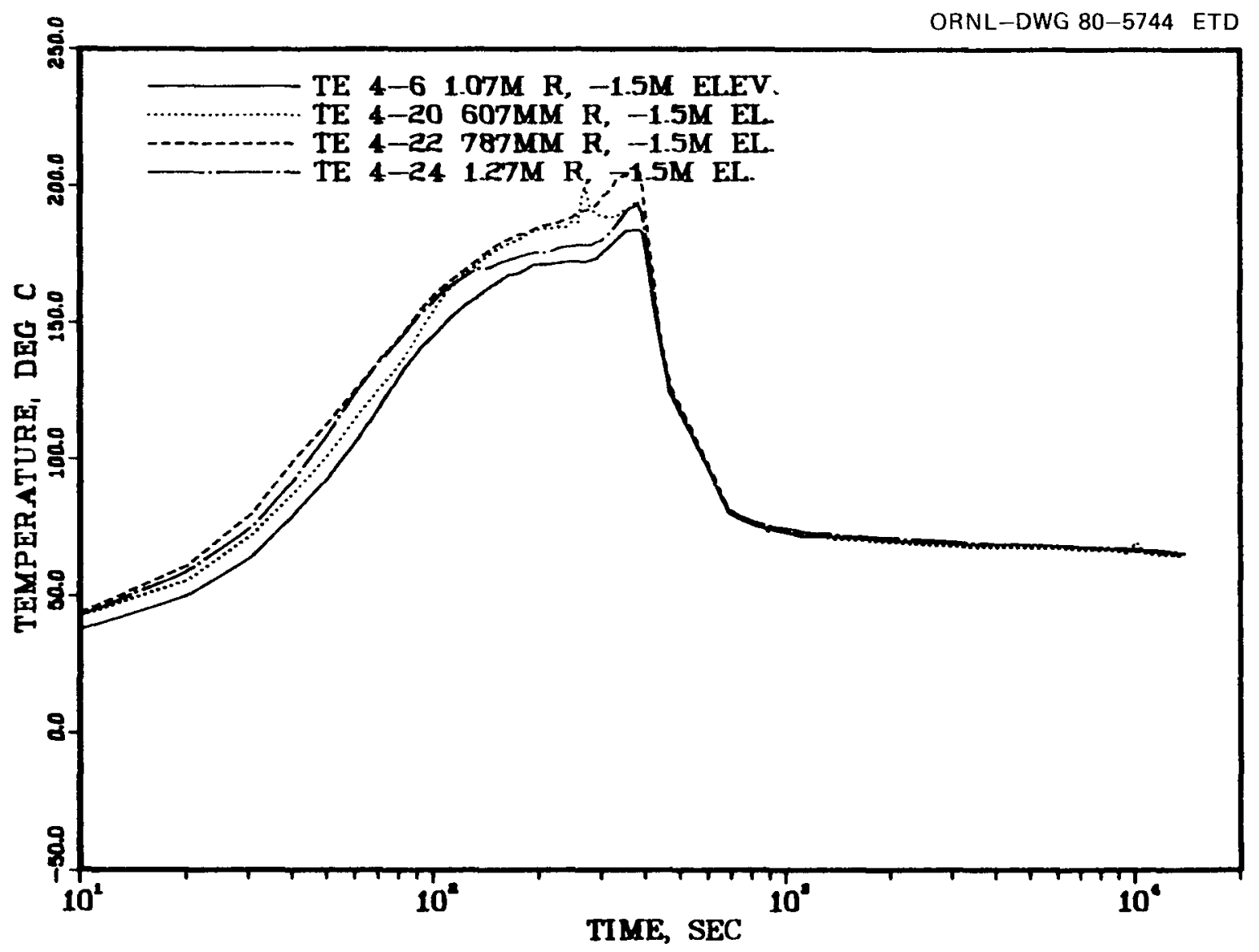

Fig. 22. Temperature measurements at $1.5 \mathrm{~m}$ below vessel midplane-NSPP Test 107 . 


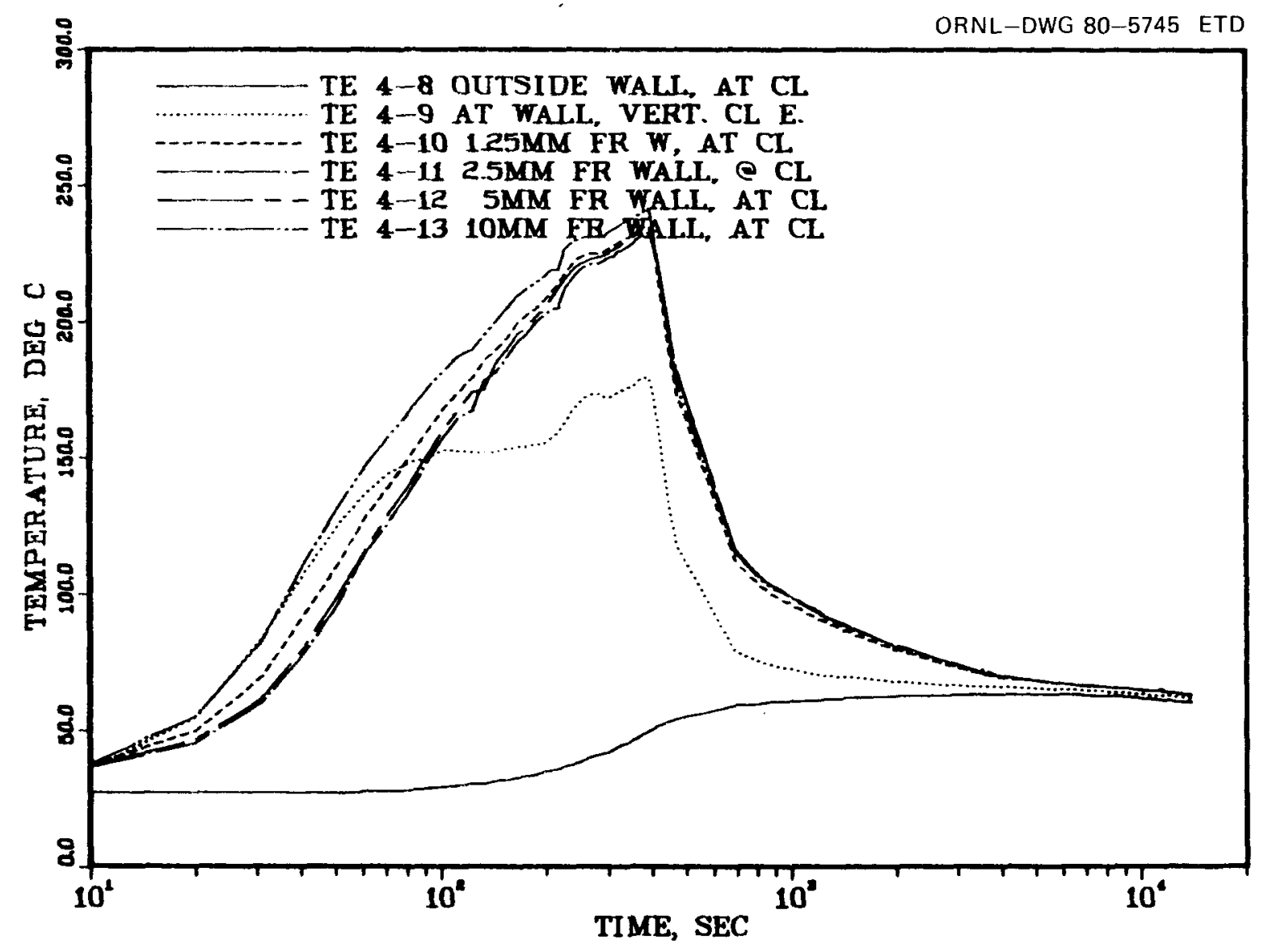

Fig. 23. Temperature measurements near the vessel wall at vessel midplane-NSPP Test 107. 


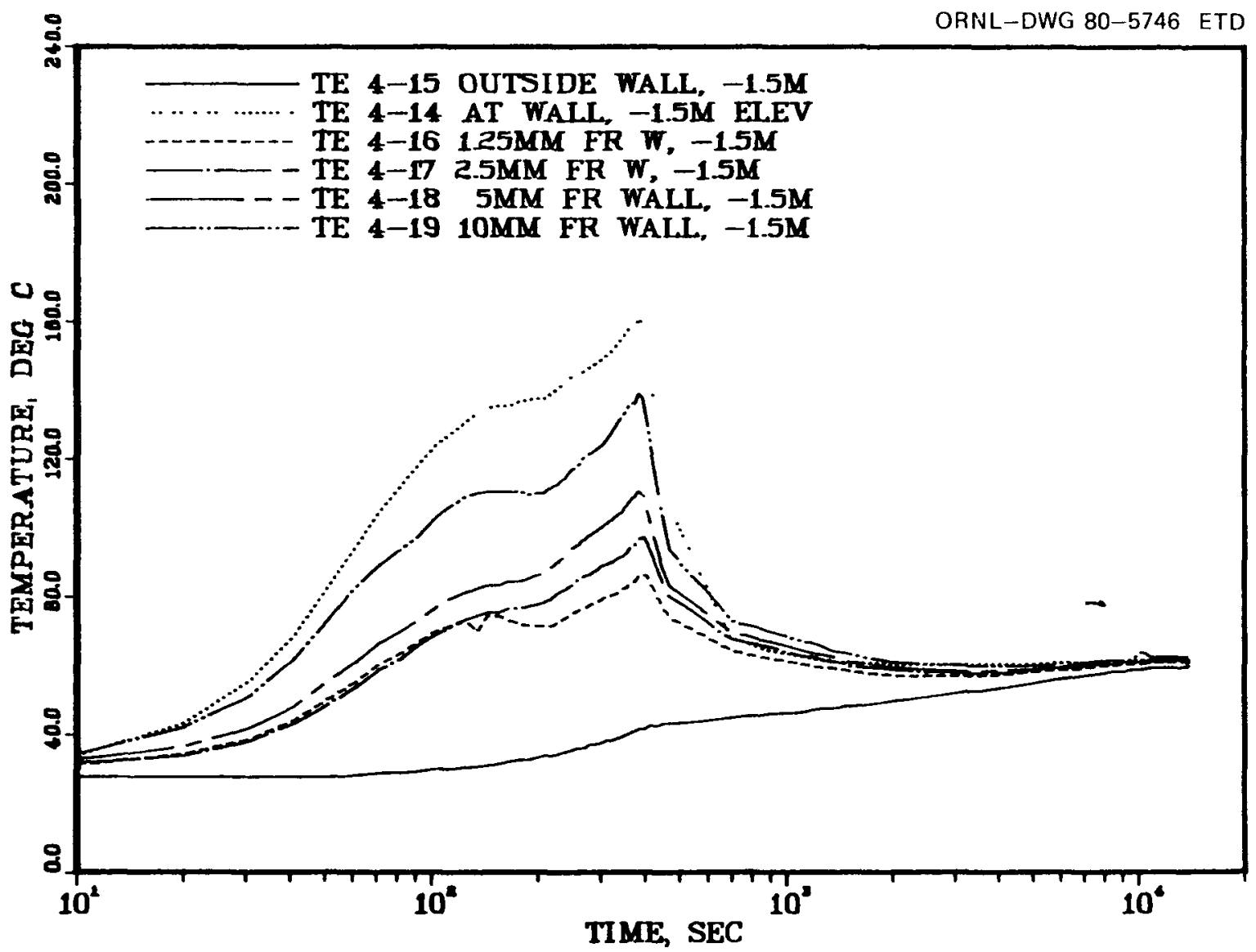

Fig. 24. Temperature measurements near the vessel wall at $1.5 \mathrm{~m}$ below vessel midplane-NSPP Test 107. 


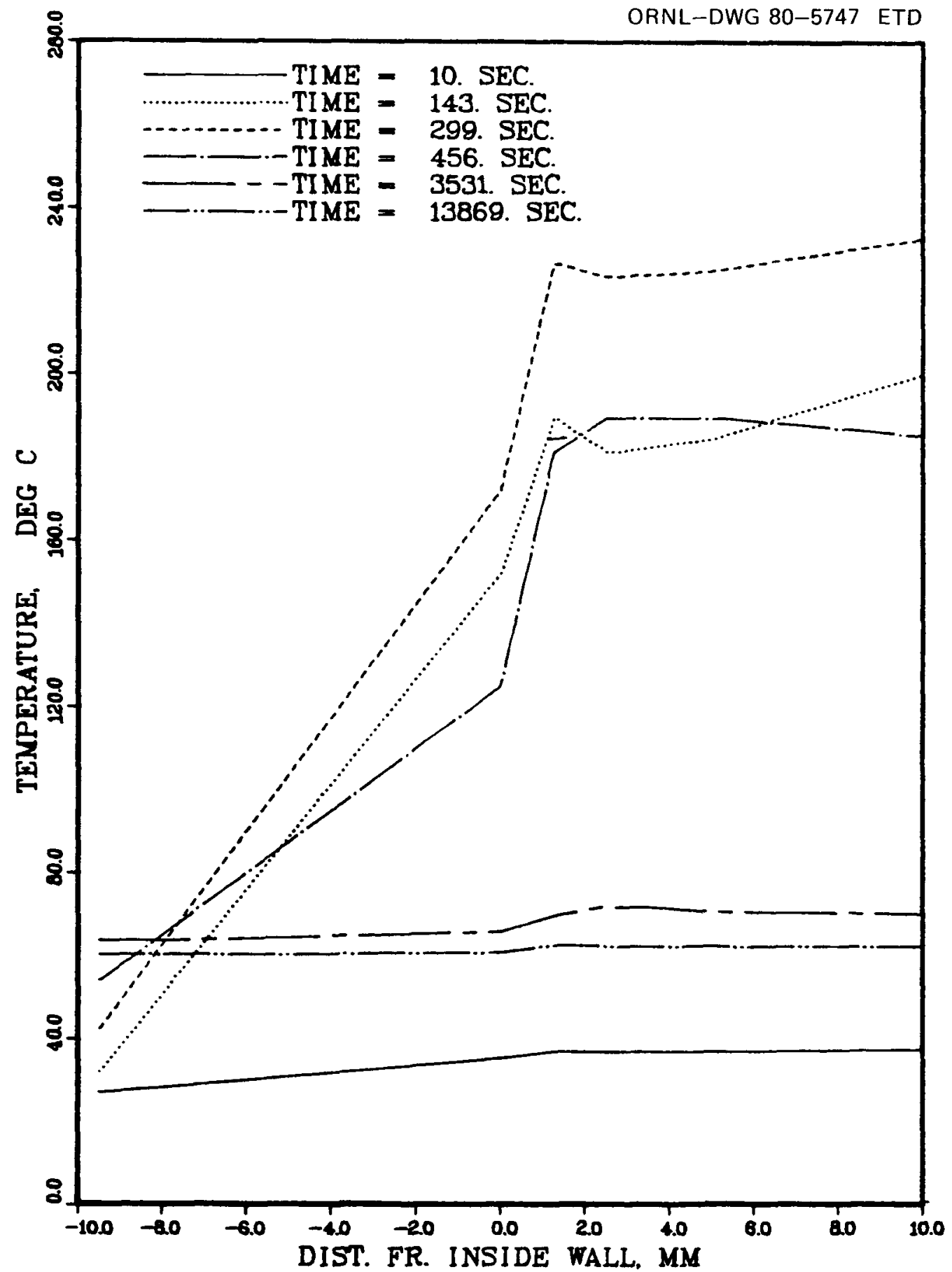

Fig. 25. Temperature profle near the vessel wall at midplane for various times after start of aerosol generation (note that the distance is measured from the inside wall toward the center of the vessel)-NSPP Test 107. 


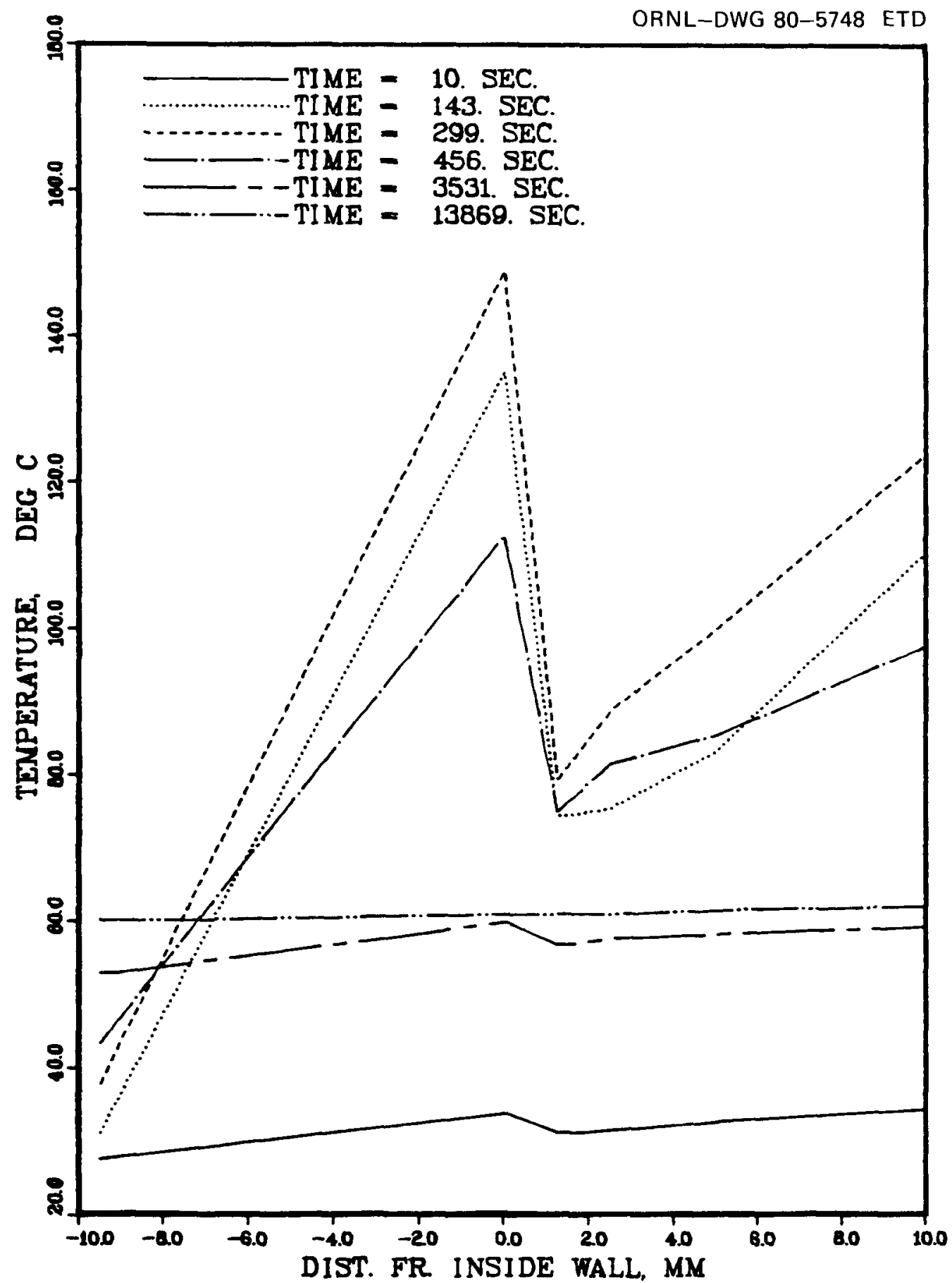

Fig. 26. Temperature profile near the vessel wall at $1.5 \mathrm{~m}$ below midplane for various times after start of aerosol generation-NSPP Test 107. 


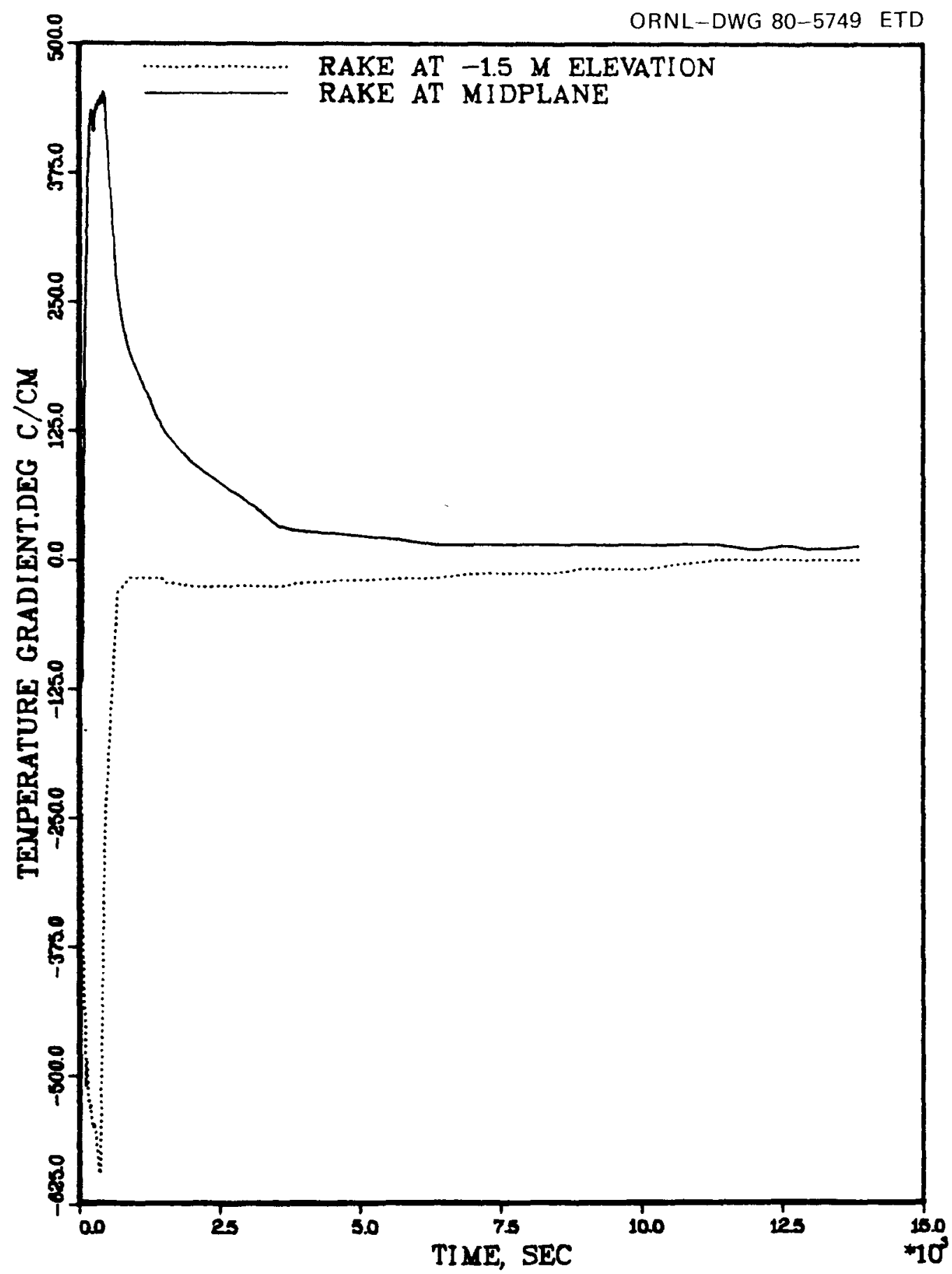

Fig. 27. Temperature gradient at the vessel wall for two elevations-NSPP Test 107. 


\subsection{Summary and Data Graphs for Test 108}

Aerosol source

Test aerosol used

$\mathrm{Na}_{2} \mathrm{O}$

Aerosol generator

Pool fire

Duration of aerosol generation

2-2 5 mın

\section{Vessel atmosphere prior to aerosol generation}

Oxygen level

$21 \%$

Relative humıdity

$<20 \%$

Temperature

Ambient

Pressure

Ambient

Duration of test operations

$48 \mathrm{~h}$

\section{Aerosol parameters measured and figure number}

Mass concentration of aerosol

Fig 28

Aerosol fallout rate

Aerosol plateout rate

Fig 29

Fig 30

Cumulatıve mass fallout and plateout

Fig 31

Aerosol particle size

Table 4

\section{System parameters measured and figure number}

Vessel atmosphere pressure

Vessel atmosphere temperatures

Fig 32

Thermal gradients at vessel wall

Figs 33-35

Figs $36-40$

\section{Posttest results}

Maximum aerosol concentration achieved

$23 \mu \mathrm{g} / \mathrm{cm}^{3}$

Aerosol distribution at end of test

Still suspended in vessel atmosphere $\quad 0002 \%$

Plated onto internal surfaces $\quad 527 \%$

Settled onto vessel floor $\quad 473 \%$

Table 4. Andersen impactor data - Test 108

\begin{tabular}{|c|c|c|c|c|c|c|c|}
\hline \multirow{2}{*}{$\begin{array}{c}\text { Aerodynamic } \\
\text { mass median } \\
\text { diameter } \\
(\mu \mathrm{m})\end{array}$} & \multicolumn{7}{|c|}{ Sample No ${ }^{a}$} \\
\hline & $\begin{array}{c}1 \\
(235 \mathrm{~m} ı \mathrm{n})\end{array}$ & $\begin{array}{c}2 \\
(566 \mathrm{~min})\end{array}$ & 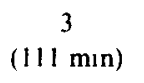 & $\begin{array}{c}4 \\
(231 \mathrm{~min})\end{array}$ & $\begin{array}{c}5 \\
(350 \mathrm{~min})\end{array}$ & $\begin{array}{c}6 \\
(596 \mathrm{~min})\end{array}$ & $\begin{array}{c}7 \\
(1445 \mathrm{mIn})\end{array}$ \\
\hline 137 & 996 & 967 & 992 & 997 & 998 & 997 & 993 \\
\hline 85 & 984 & 905 & 961 & 988 & 996 & 995 & 989 \\
\hline 58 & 887 & 768 & 739 & 849 & 933 & 989 & 982 \\
\hline 40 & 704 & 453 & 370 & 595 & 751 & 920 & 973 \\
\hline 25 & 266 & 153 & 129 & 235 & 312 & 608 & 891 \\
\hline 13 & 42 & 40 & 29 & 28 & 58 & 253 & 298 \\
\hline 078 & 18 & 23 & 14 & 11 & 18 & 184 & 155 \\
\hline 053 & 16 & 21 & 12 & 09 & 15 & 181 & 137 \\
\hline
\end{tabular}

${ }^{a}$ Percent of mass associated with diameters smaller than indicated size 


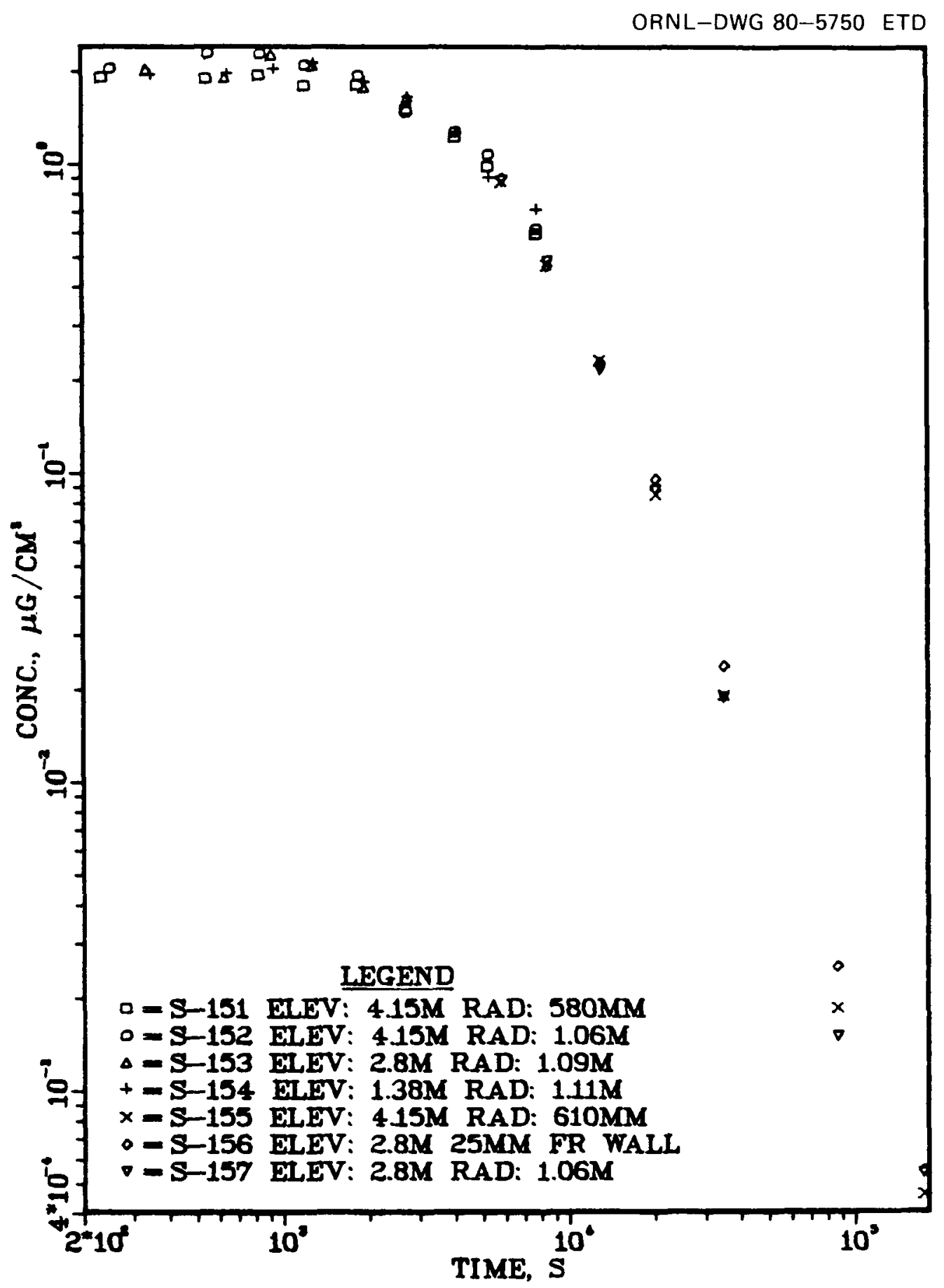

Fig. 28. Aerosol mass concentrations vs time-NSPP Test 108. 


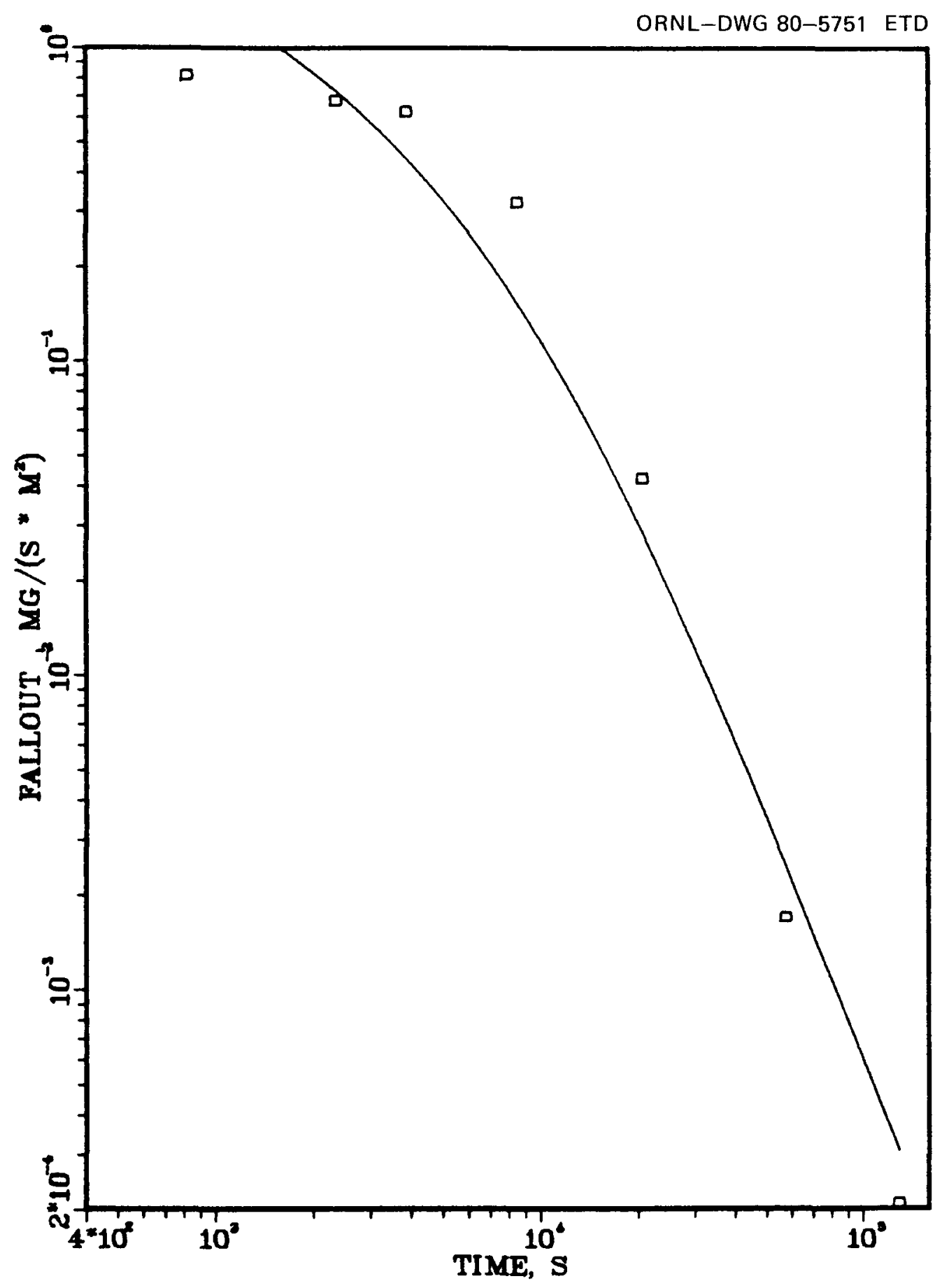

Fig. 29. Fallout rate vs time-NSPP Test 108. 


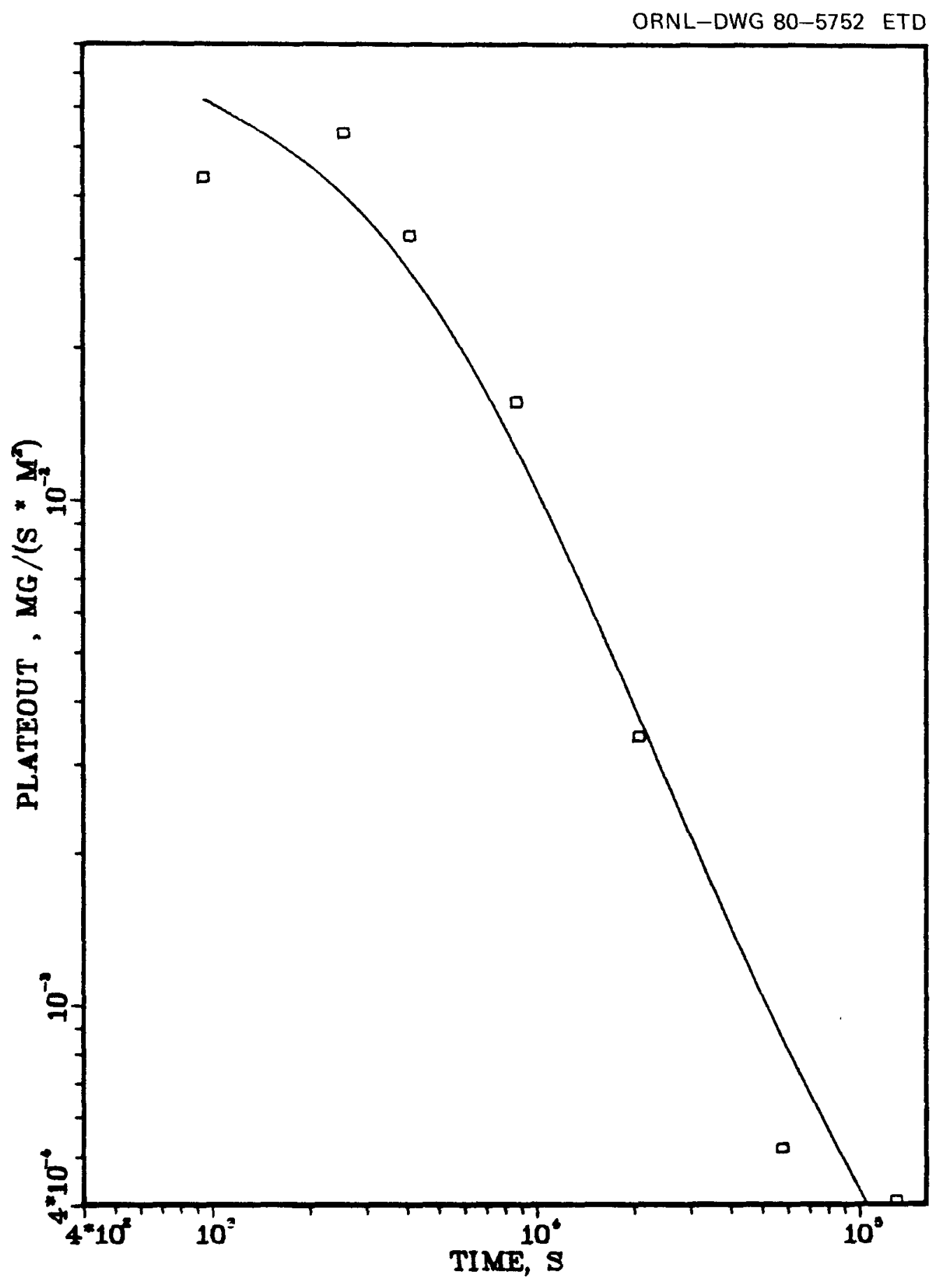

Fig. 30. Plateout rate vs time-NSPP Test 108. 


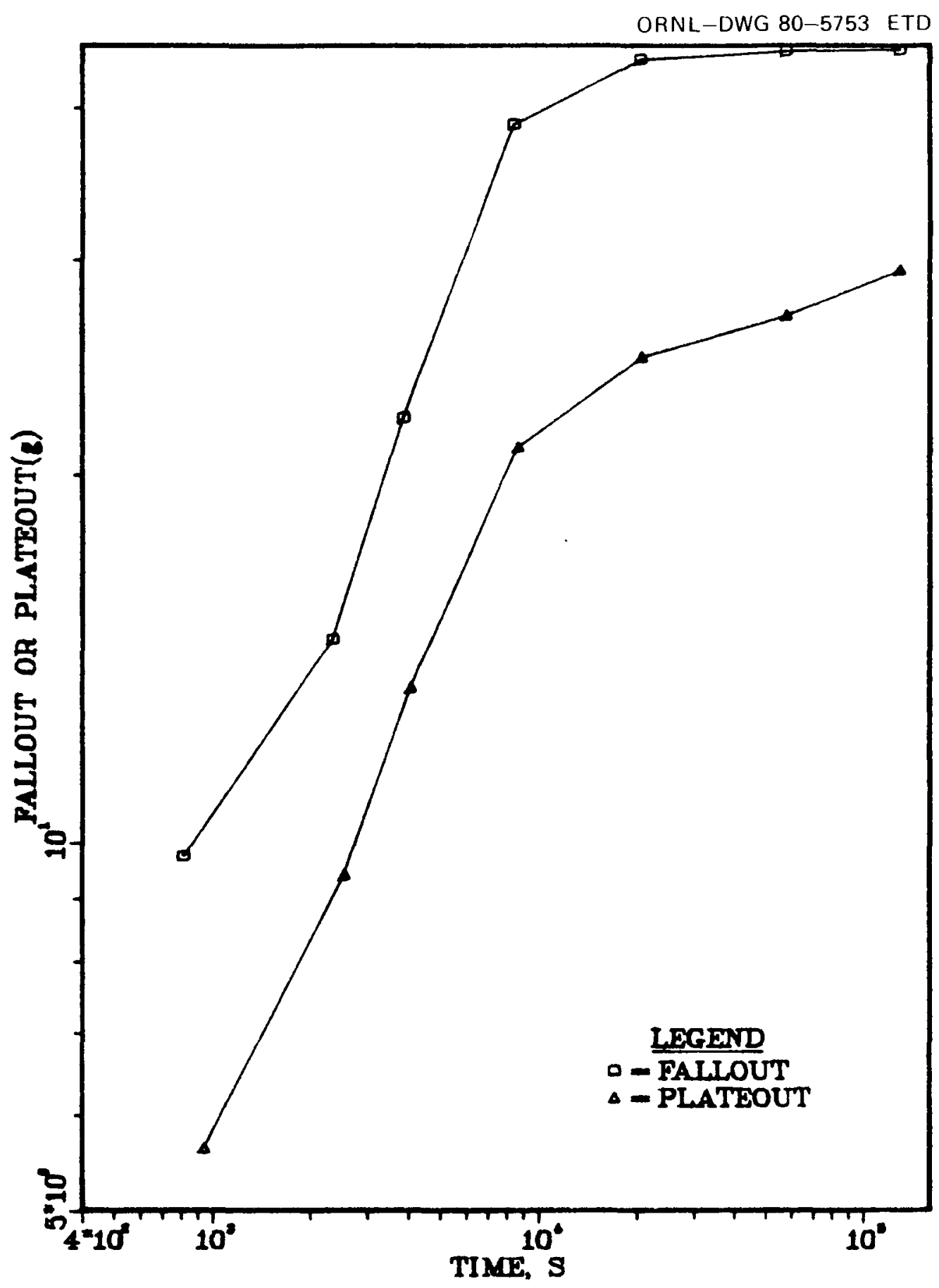

Fig. 31. Cumulative fallout and plateout mass vs ume-NSPP Test 108. 


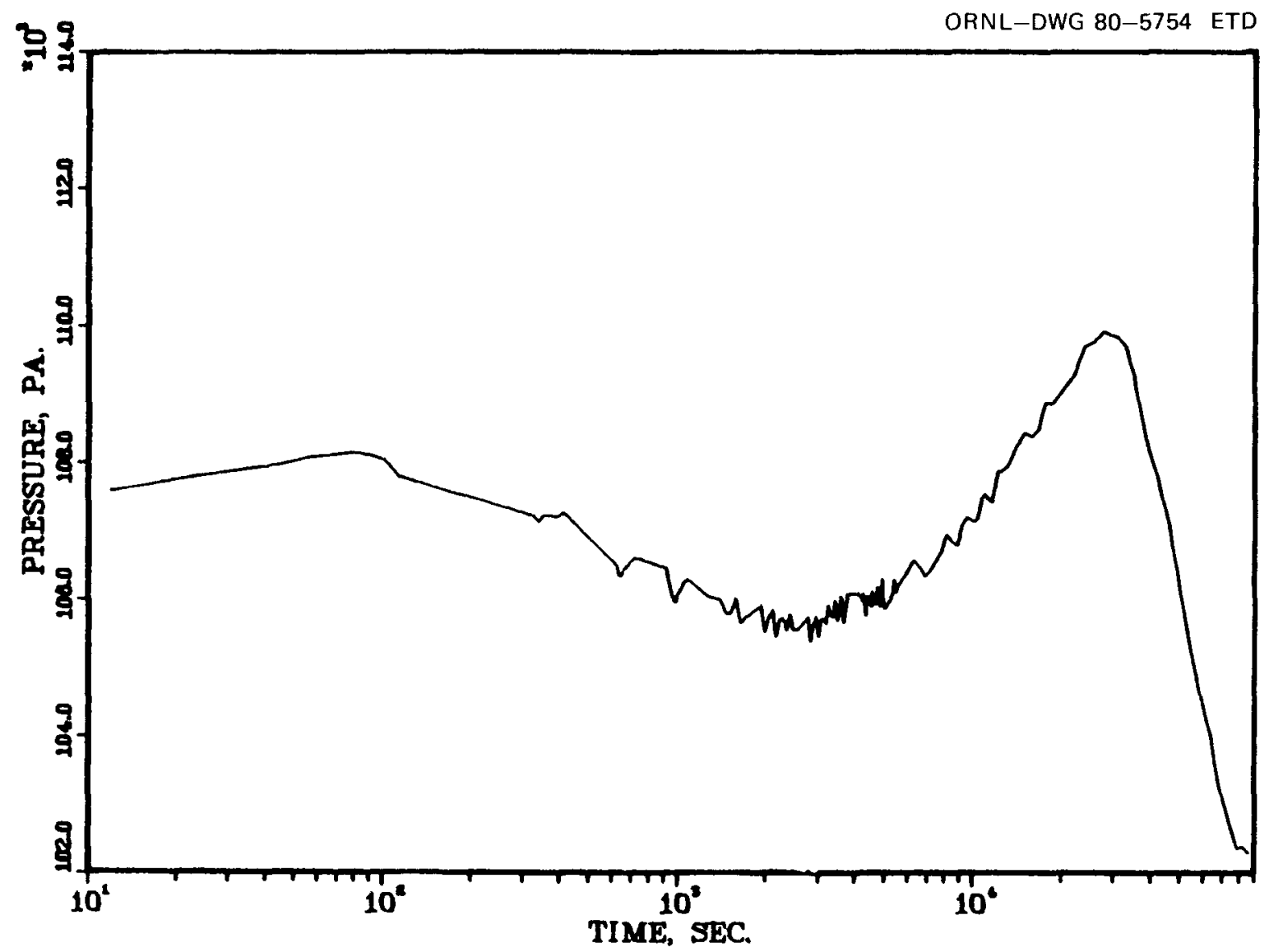

Fig. 32. In-vessel pressure vs time-NSPP Test 108. 


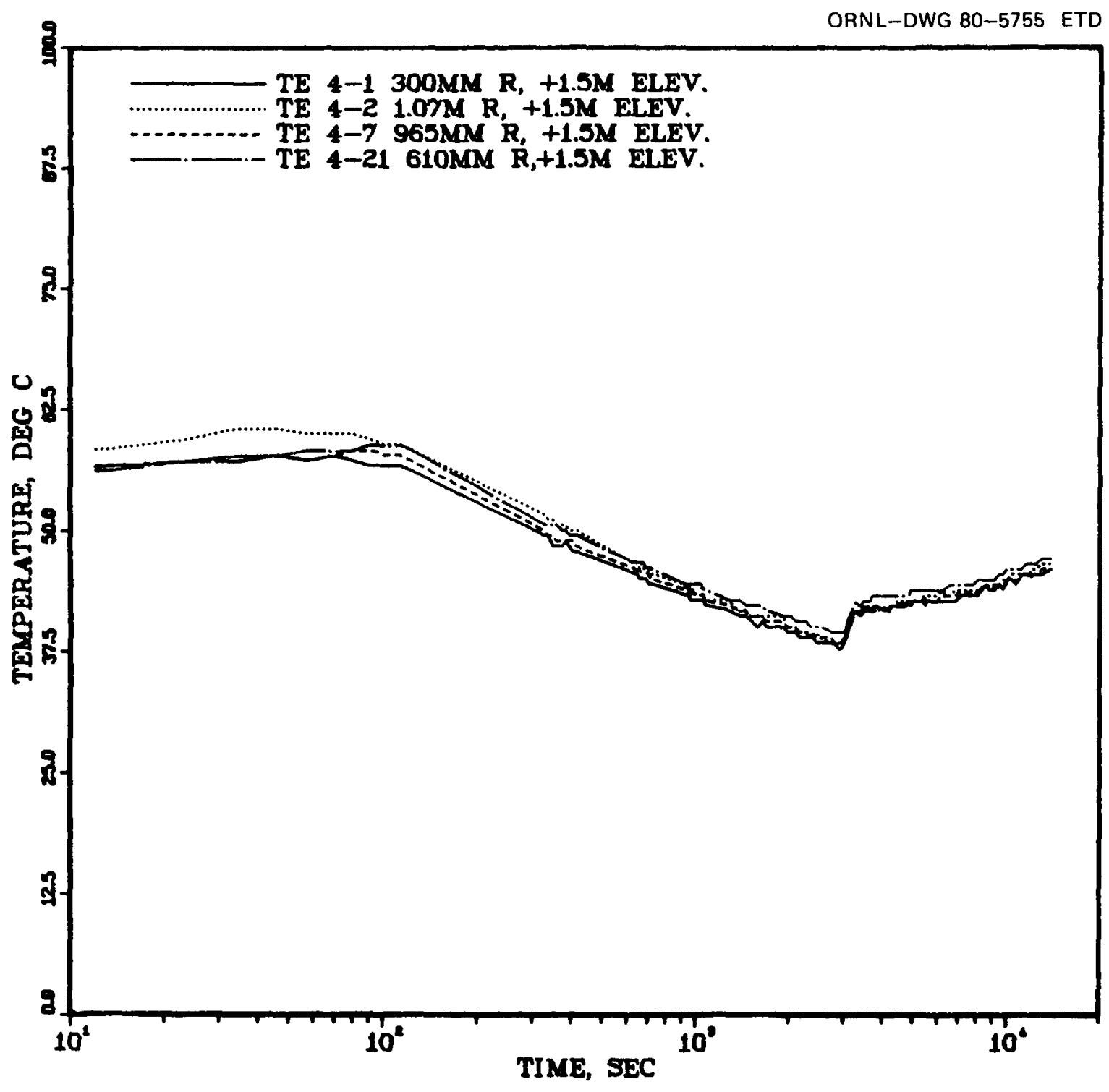

Fig. 33. Temperature measurements at $1.5 \mathrm{~m}$ above vessel midplane-NSPP Test 108. 


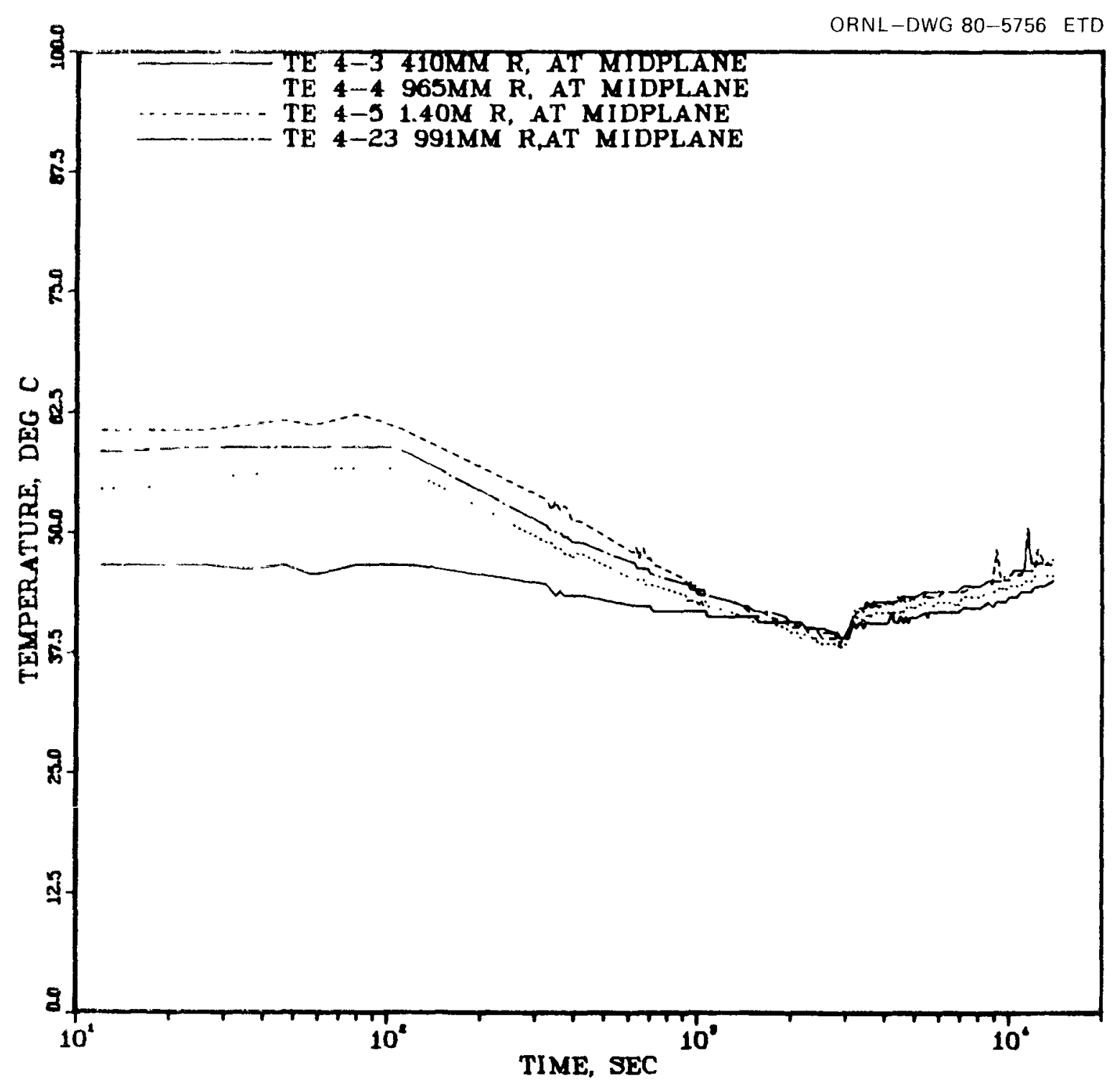

Fig. 34. Temperature measurements at vessel midplane-NSPP Test 108. 


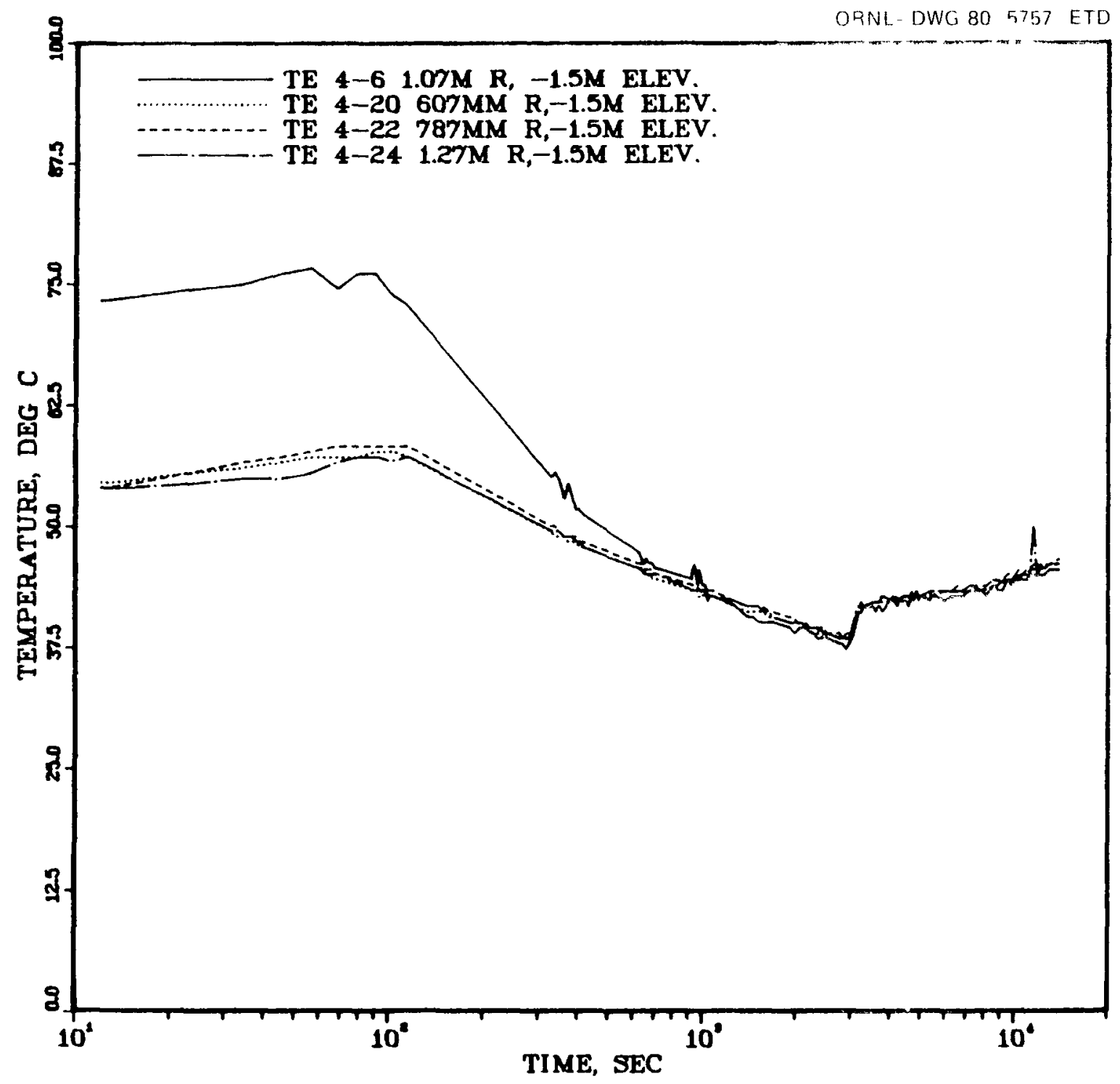

Fig. 35. Temperature measurements at $1.5 \mathrm{~m}$ below vessel midplane-NSPP Test 108 . 


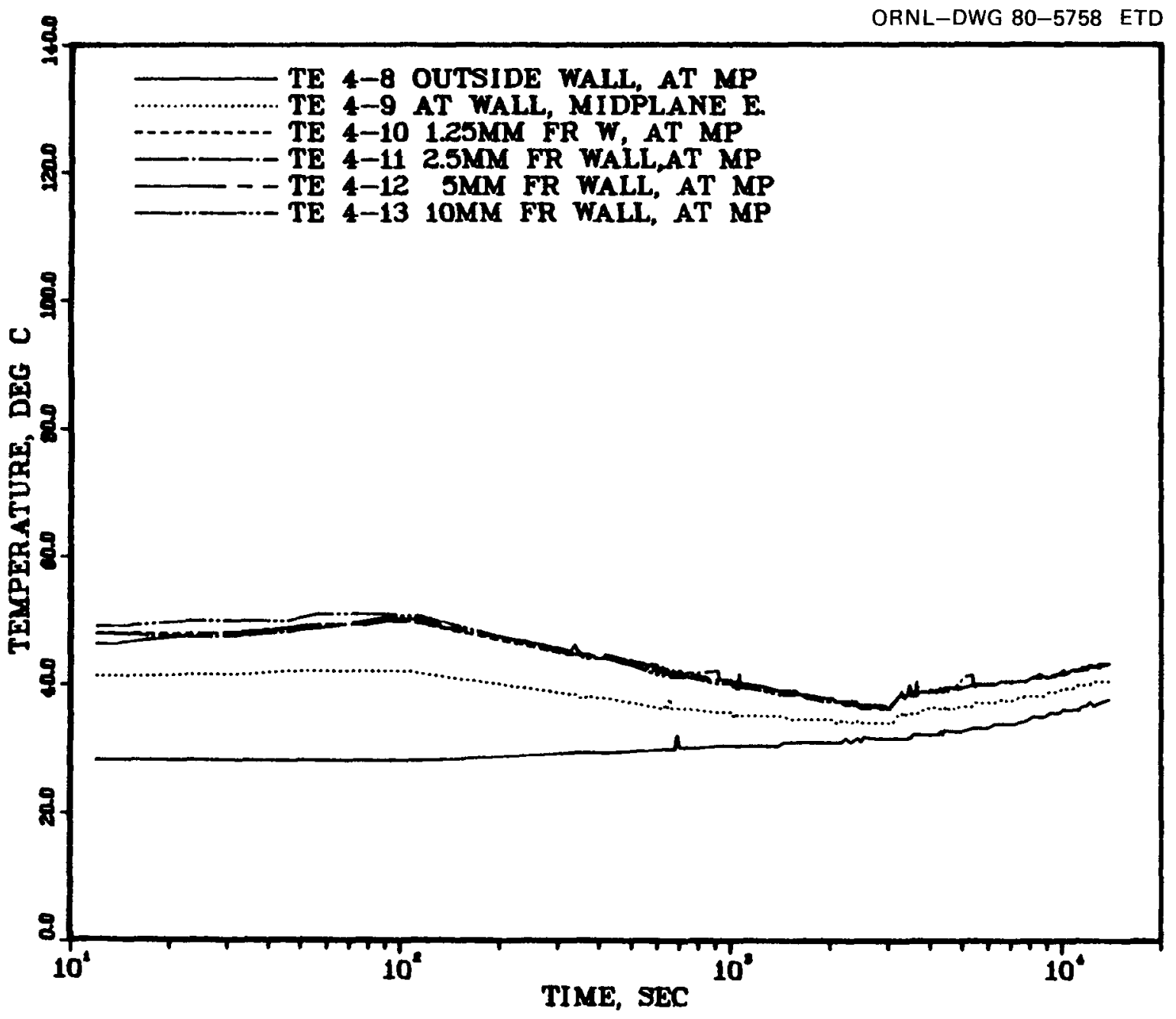

Fig. 36. Temperature measurements near the vessel wall at vessel midplane-NSPP Test 108. 


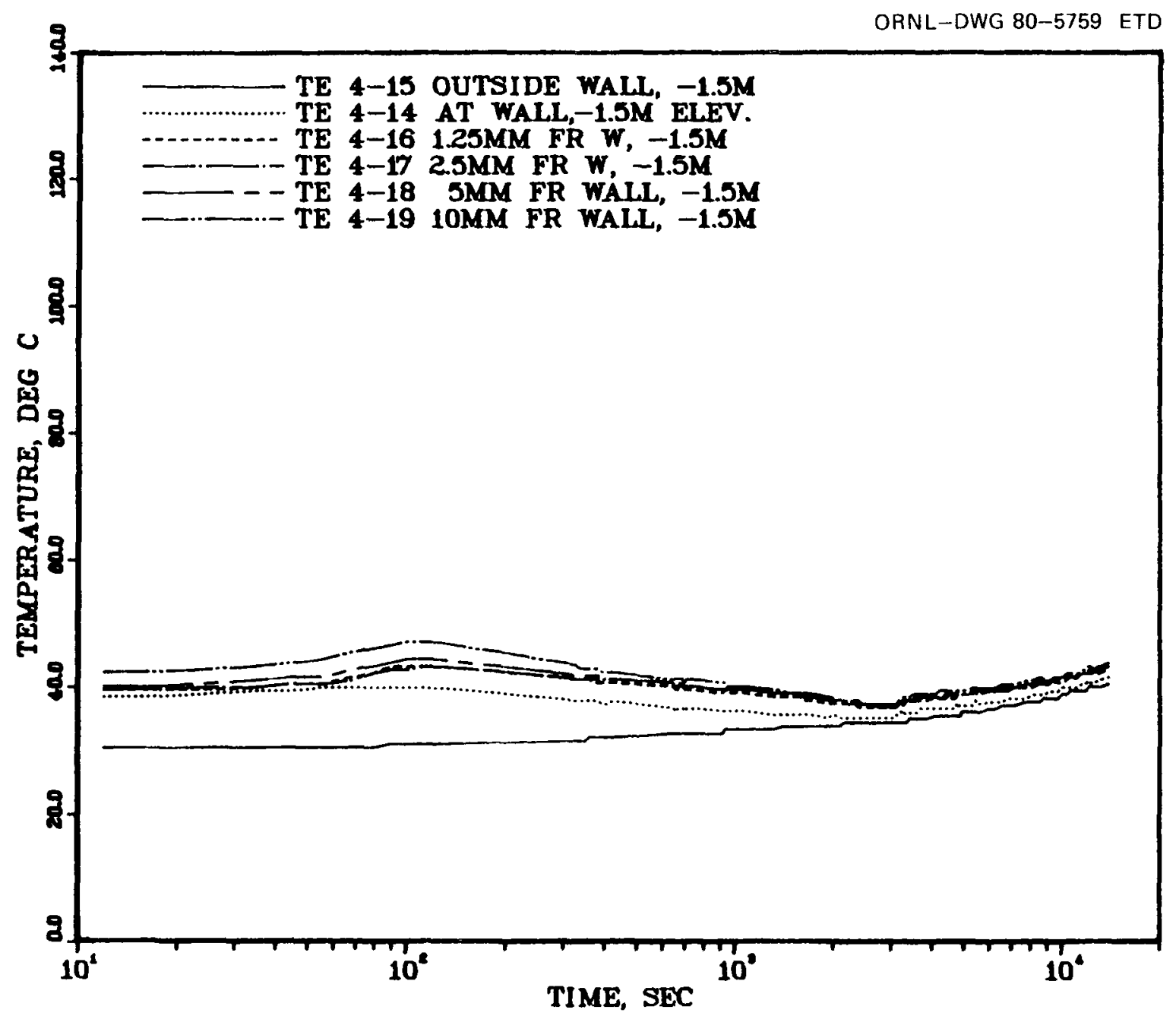

Fig. 37. Temperature measurements near the vessel wall at $1.5 \mathrm{~m}$ below vessel midplane-NSPP Test 108 . 


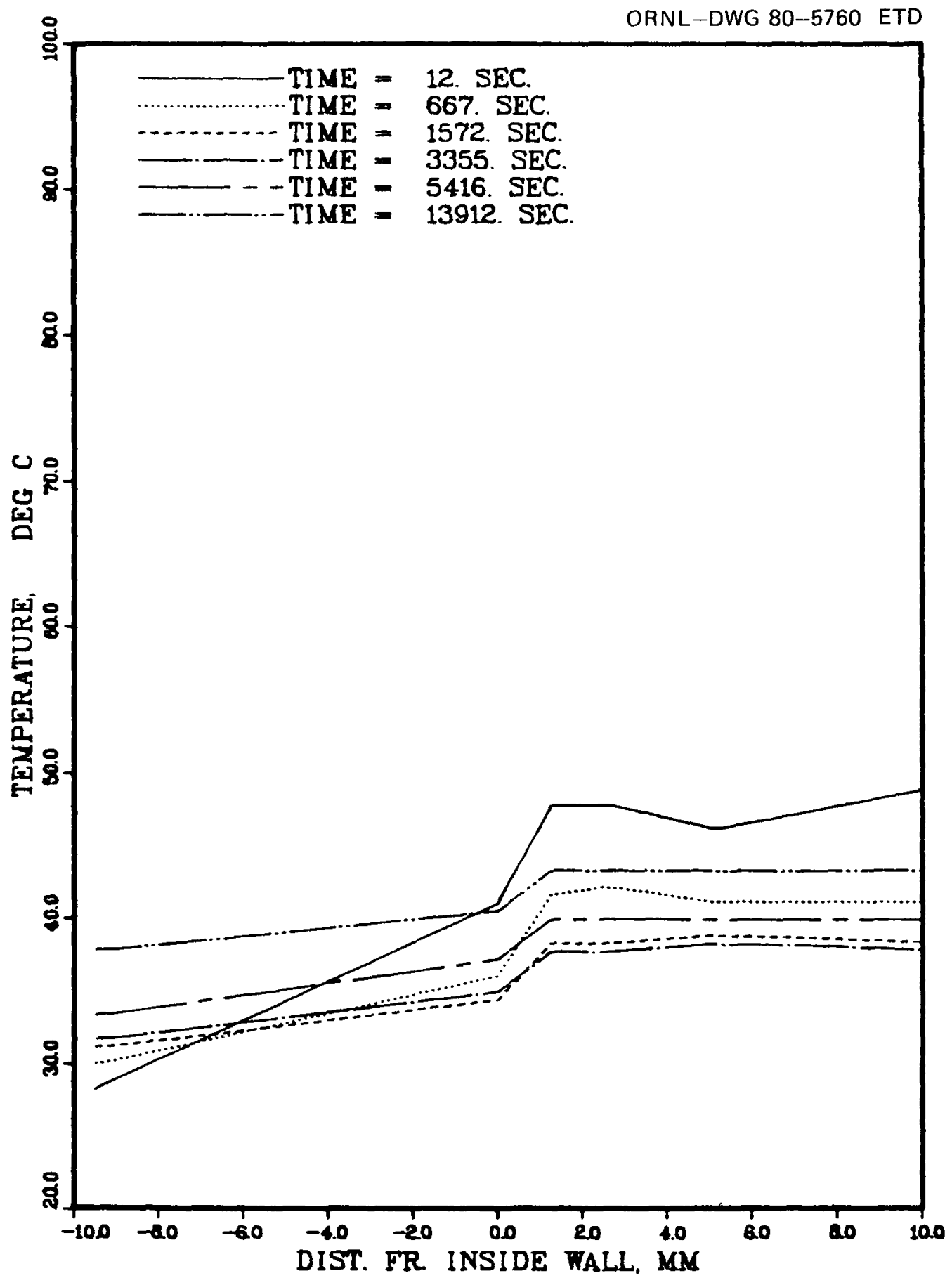

Fig. 38. Temperature profile near the vessel wall midplane for various times after start of aerosol generation (note that the distance is measured from the inside wall toward the center of the vessel)-NSPP Test 108. 


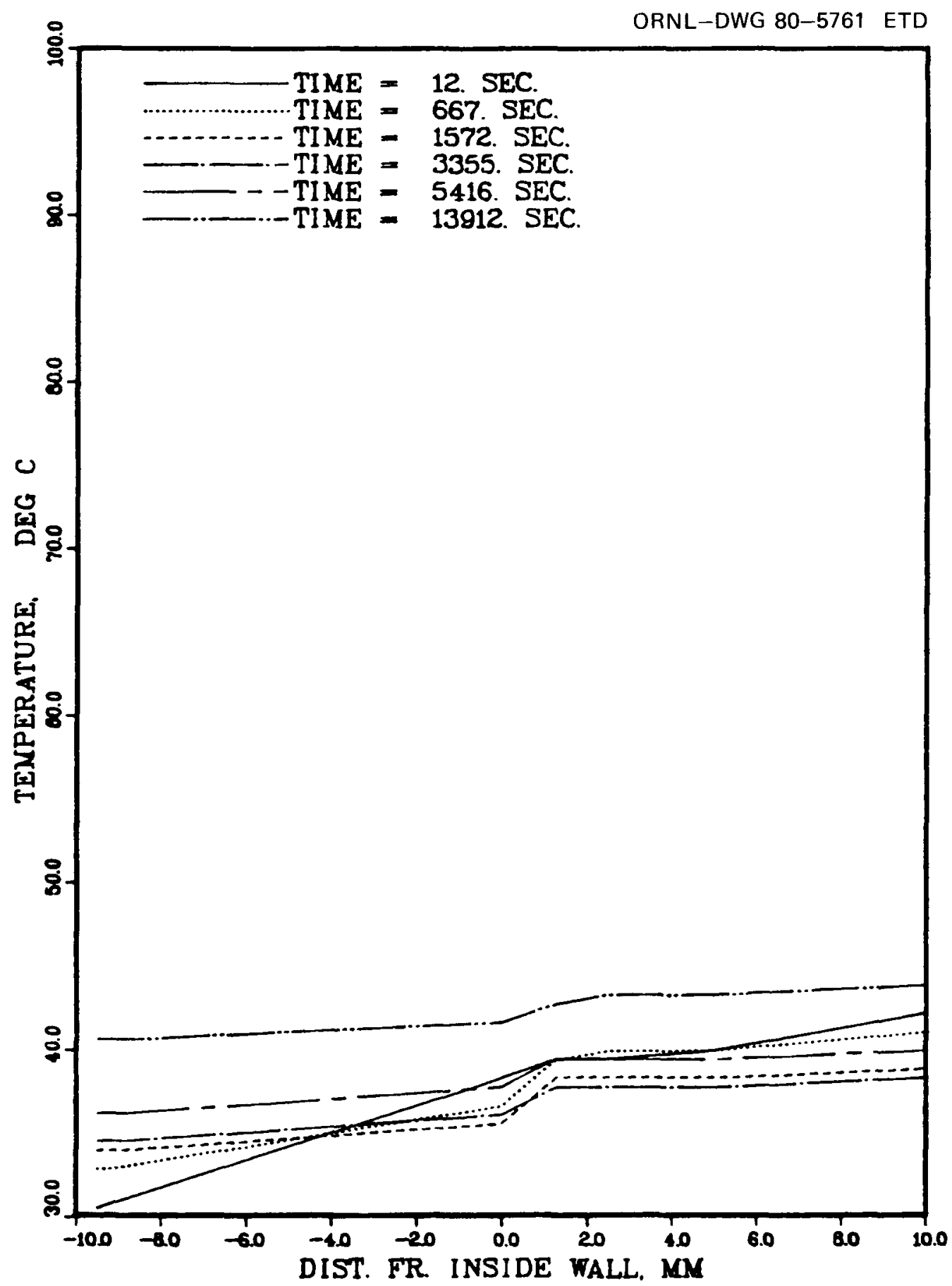

Fig. 39. Temperature profile near the vessel wall at $1.5 \mathrm{~m}$ below midplane for various times after start of aerosol generation-NSPP Test 108. 


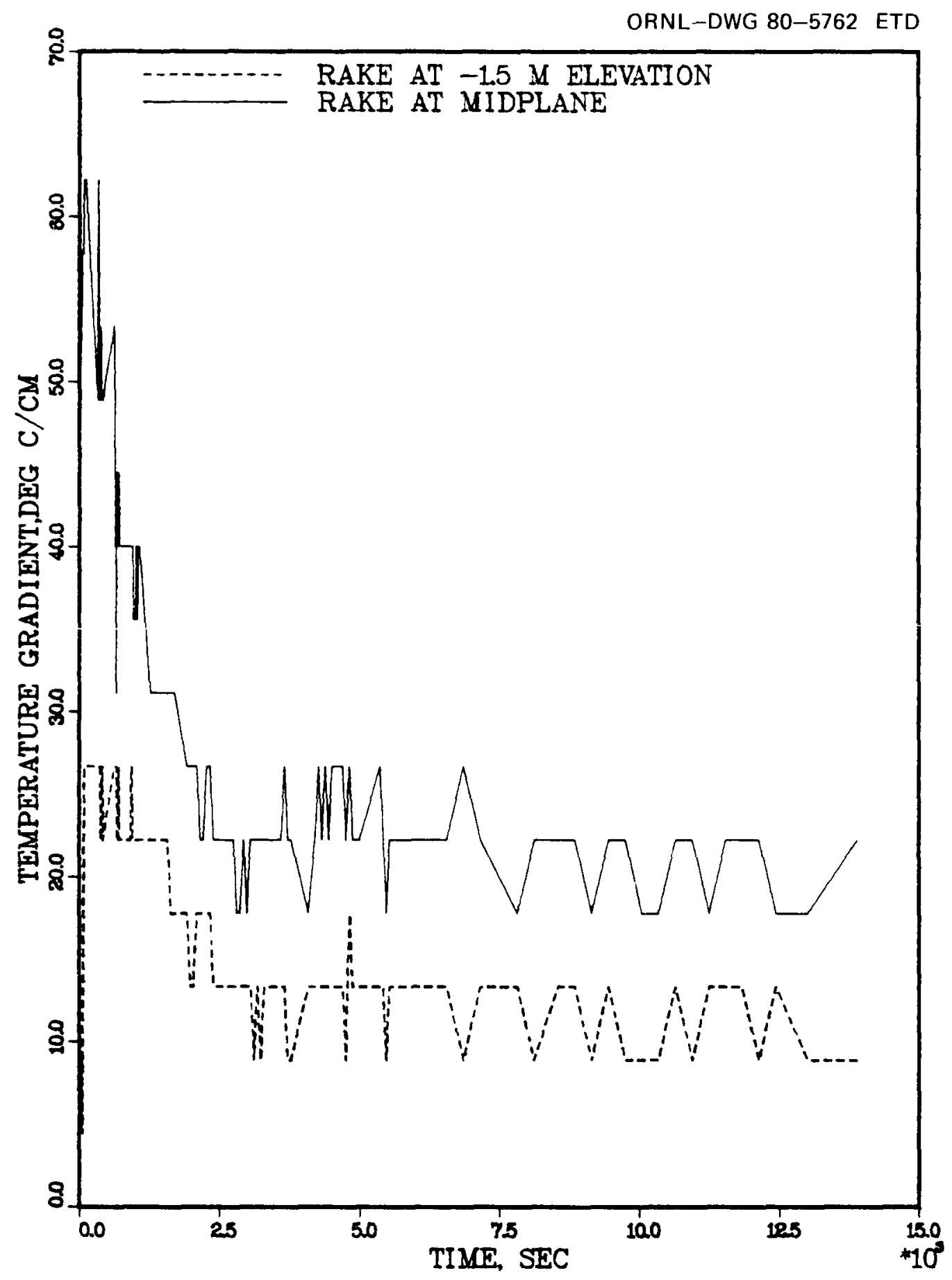

Fig. 40. Temperature gradient at the vessel wall for two elevations-NSPP Test 108. 


\subsection{Summary and Data Graphs for Test 204}

\section{Aerosol source}

Test aerosol used

Aerosol generator

Duration of aerosol generation

$\mathrm{U}_{3} \mathrm{O}_{8}$

Plasma torch

2-20 min

Vessel atmosphere prior to aerosol generation

$\begin{array}{ll}\text { Oxygen level } & 21 \% \\ \text { Relative humidity } & <20 \% \\ \text { Temperature } & \text { Ambient }\end{array}$

Pressure

Ambient

Duration of test operations

$48 \mathrm{~h}$

\section{Aerosol parameters measured and figure number}

Mass concentration of aerosol

Fig. 41

Aerosol fallout rate

Fig. 42

Aerosol plateout rate

Fig. 43

Cumulative mass fallout and plateout

Fig. 44

Aerosol particle size

Table 5

\section{System parameters measured and figure number}

Vessel atmosphere pressure

Fig. 45

Vessel atmosphere temperatures

Figs. 46-48

Thermal gradients at vessel wall

Figs. $49-53$

\section{Posttest results}

Maximum aerosol concentration achieved

$0.7 \mu \mathrm{g} / \mathrm{cm}^{3}$

Aerosol distribution at end of test

Still suspended in vessel atmosphere

$0.003 \%$

Plated onto internal surfaces

$60.0 \%$

Settled onto vessel floor

$40.0 \%$

Table 5. Andersen impactor data - Test 204

\begin{tabular}{ccccccccc}
\hline $\begin{array}{c}\text { Aerodynamic } \\
\text { mass median } \\
\text { diameter }\end{array}$ & \begin{tabular}{c}
\multicolumn{7}{c}{ Sample No. } \\
\cline { 2 - 8 }$(\mu \mathrm{m})$
\end{tabular} & \begin{tabular}{c}
1 \\
\cline { 2 - 8 } $\mathrm{min})$
\end{tabular} & $\begin{array}{c}2 \\
(47 \mathrm{~min})\end{array}$ & $\begin{array}{c}3 \\
(87 \mathrm{~min})\end{array}$ & $\begin{array}{c}4 \\
(177 \mathrm{~min})\end{array}$ & $\begin{array}{c}5 \\
(347 \mathrm{~min})\end{array}$ & $\begin{array}{c}6 \\
(586 \mathrm{~min})\end{array}$ & $(1458 \mathrm{~min})$ \\
\hline 13.7 & 99.6 & 99.6 & 99.0 & 98.3 & 97.1 & 99.1 & 99.2 \\
8.5 & 99.4 & 99.3 & 98.5 & 97.5 & 96.2 & 98.8 & 99.0 \\
5.8 & 98.7 & 97.6 & 96.8 & 91.6 & 92.7 & 97.9 & 98.6 \\
4.0 & 97.8 & 91.2 & 89.3 & 74.1 & 74.9 & 92.6 & 97.9 \\
2.5 & 93.2 & 65.7 & 62.1 & 38.6 & 44.3 & 62.7 & 92.5 \\
1.3 & 58.3 & 28.9 & 26.0 & 7.9 & 7.2 & 16.9 & 29.7 \\
0.78 & 18.0 & 7.5 & 4.0 & 0.9 & 1.1 & 2.6 & 5.2 \\
0.53 & 1.7 & 0.2 & 0.6 & 0.1 & 0.3 & 0.5 & 1.5 \\
\hline
\end{tabular}

${ }^{a}$ Percent of mass associated with diameters smaller than indicated size. 


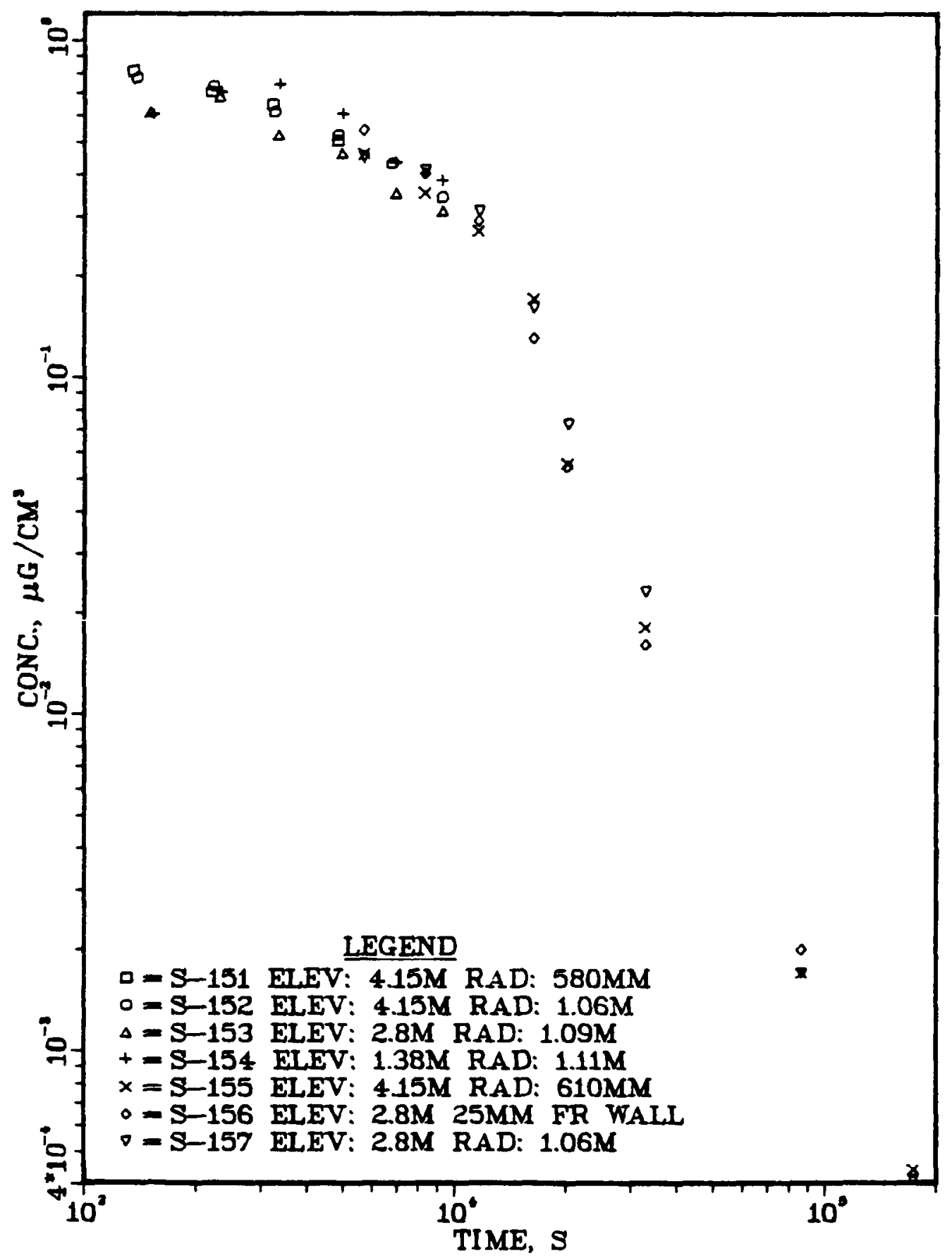

Fig. 41. Aerosol mass concentrations vs time-NSPP Test 204. 


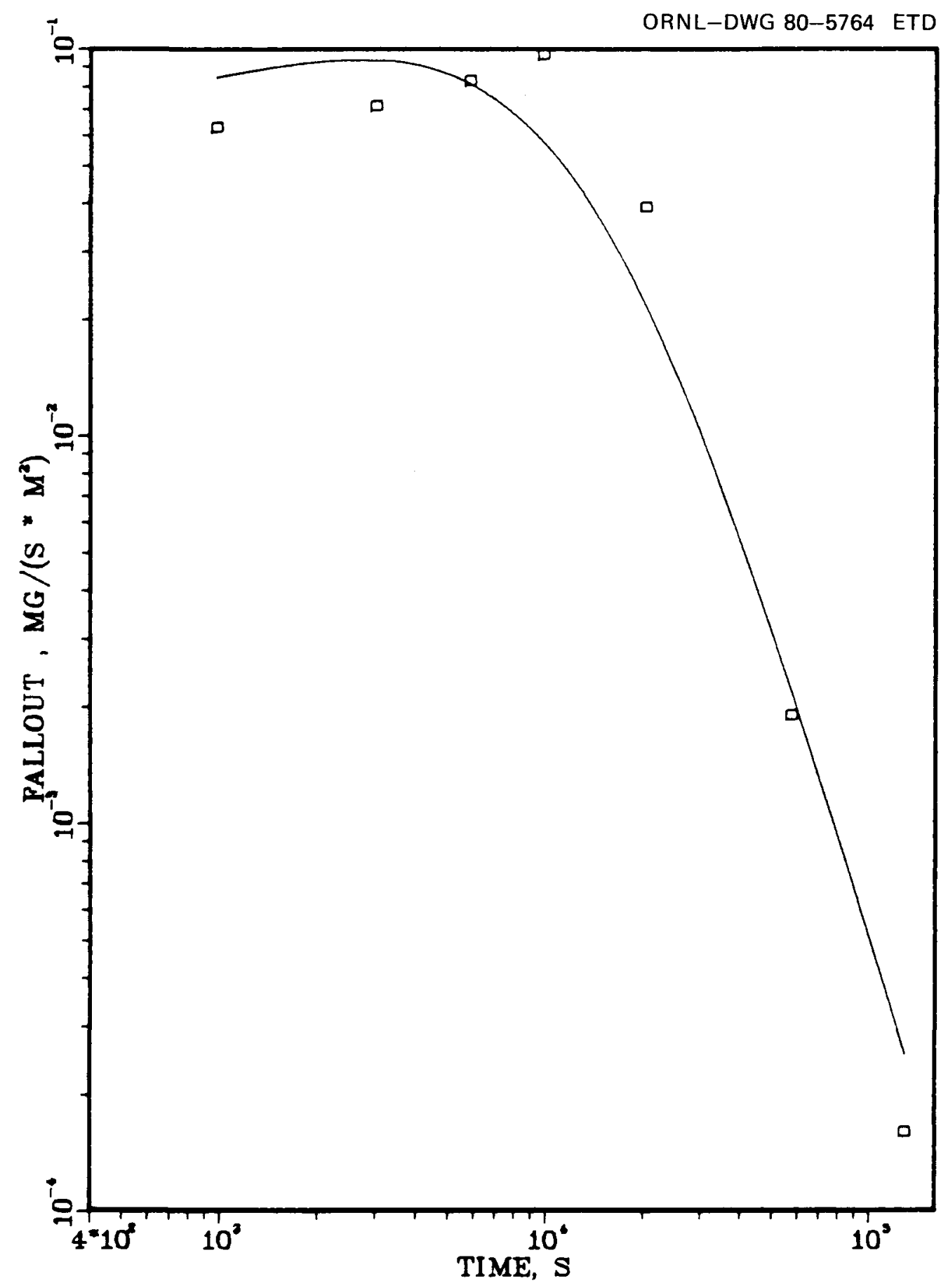

Fig. 42. Fallout rate vs time-NSPP Test 204. 


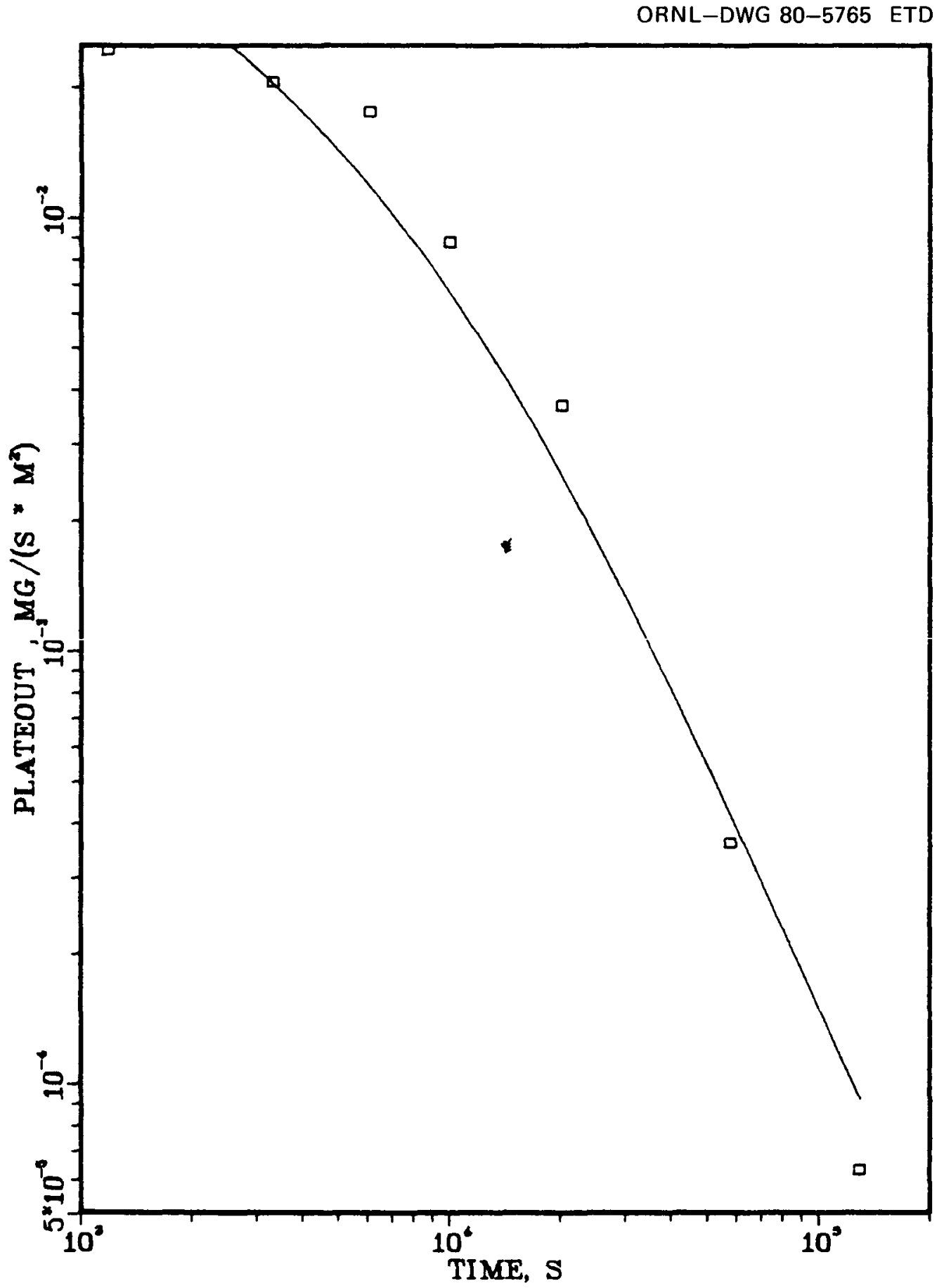

Fig. 43. Plateout rate vs time-NSPP Test 204. 


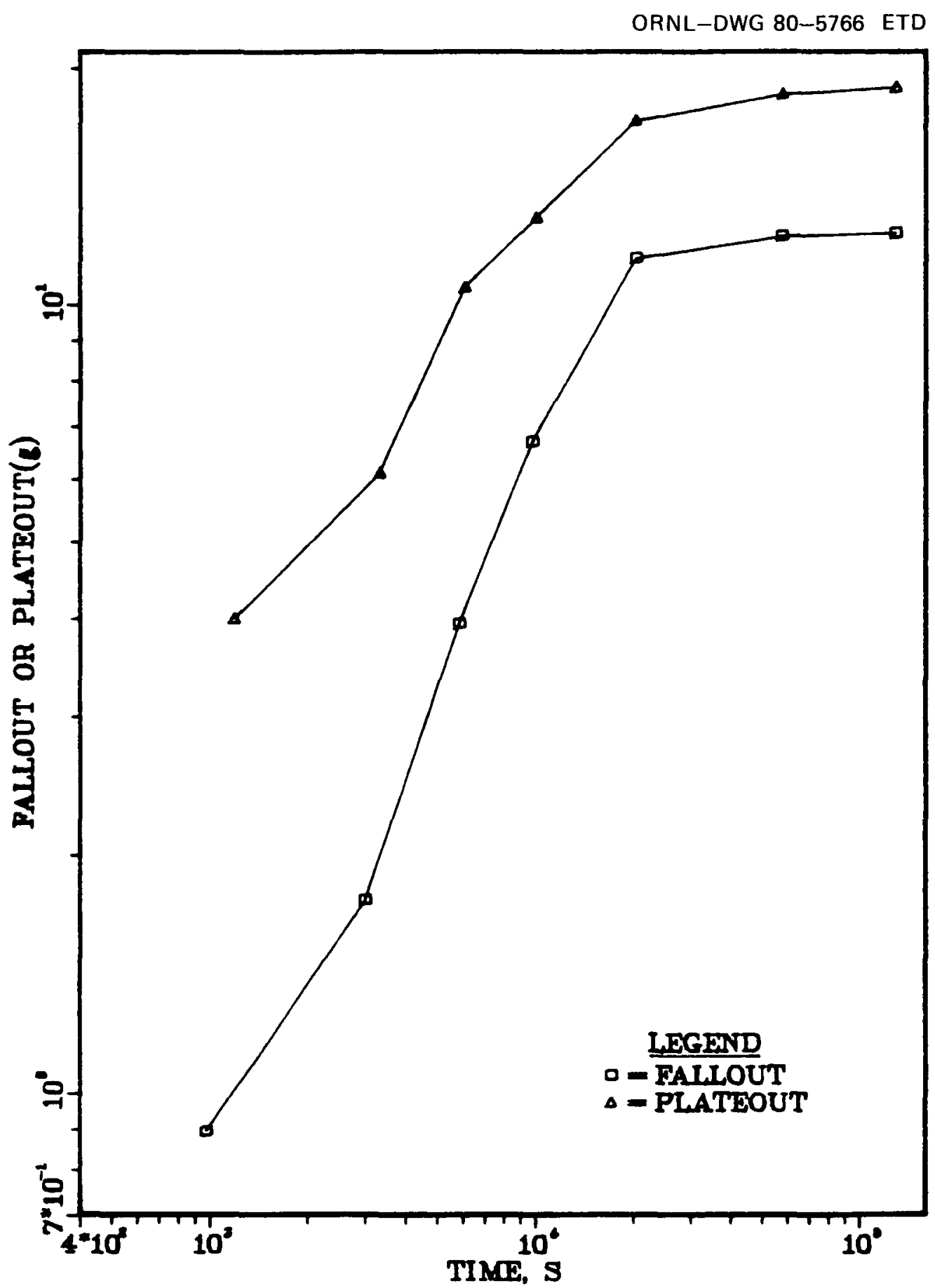

Fig. 44. Cumulative fallout and plateout mass vs time-NSPP Test 204. 


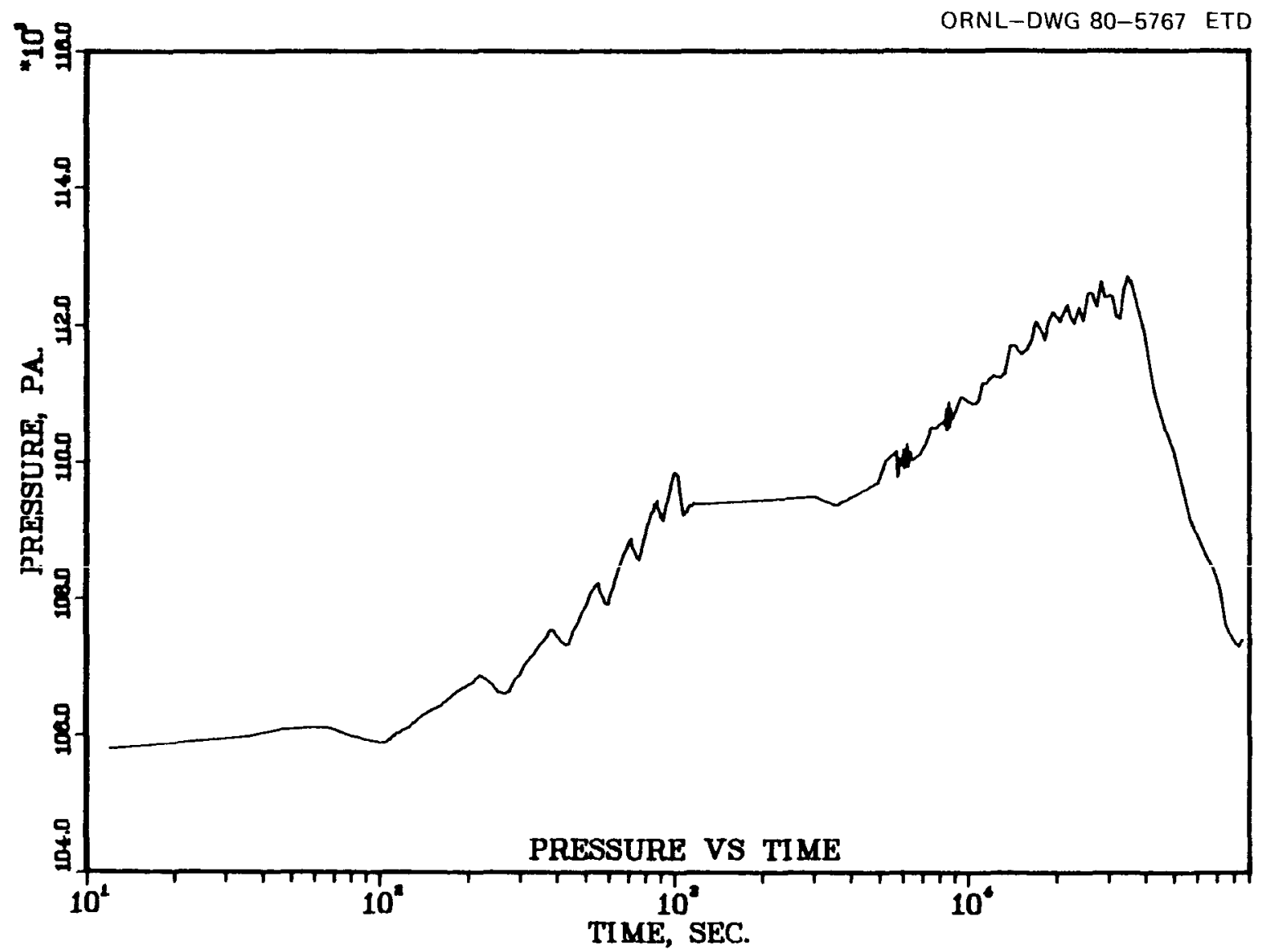

Fig. 45. In-vessel pressure vs time-NSPP Test 204. 


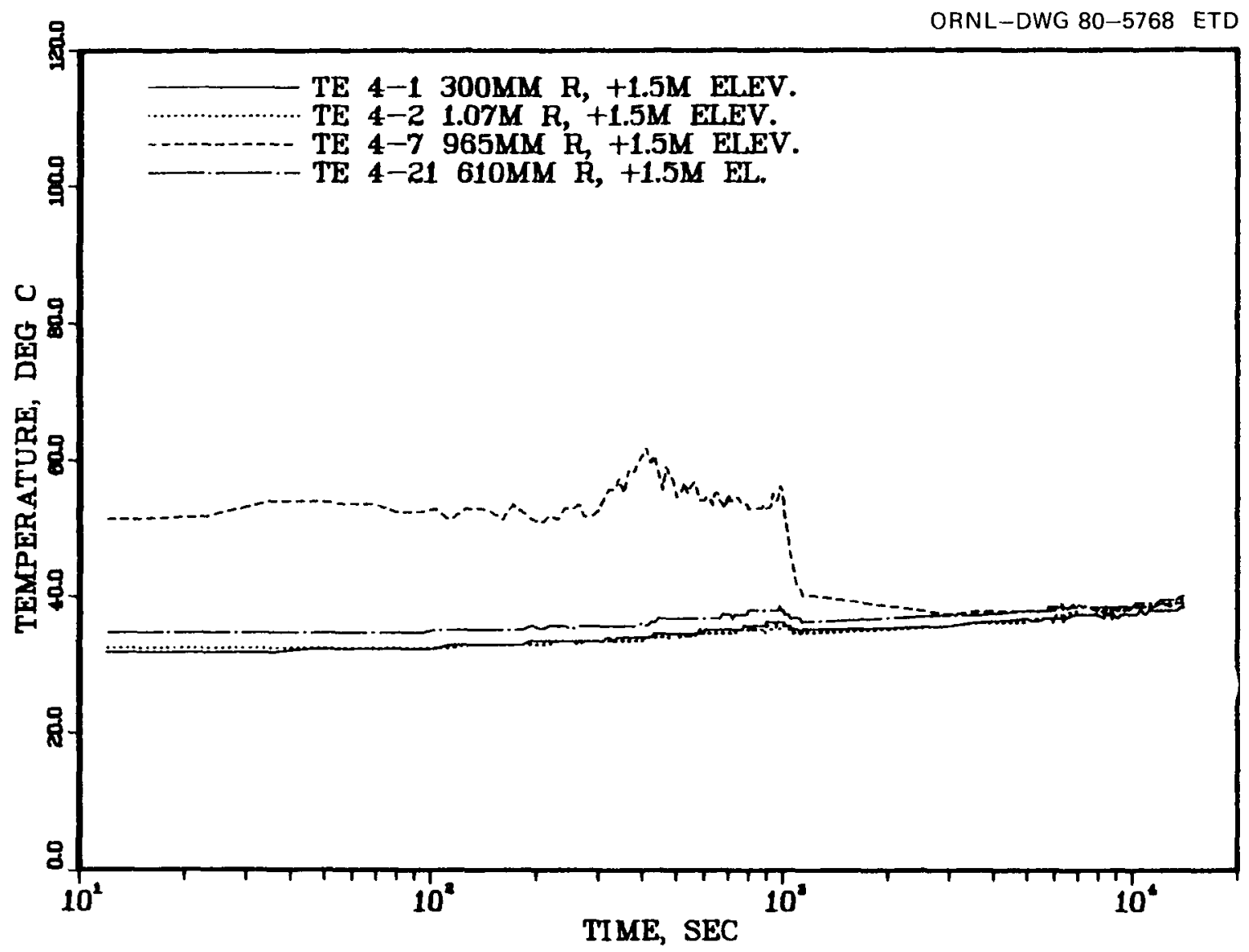

Fig. 46. Temperature measurements at $1.5 \mathrm{~m}$ above vessel midplane-NSPP Test 204. 


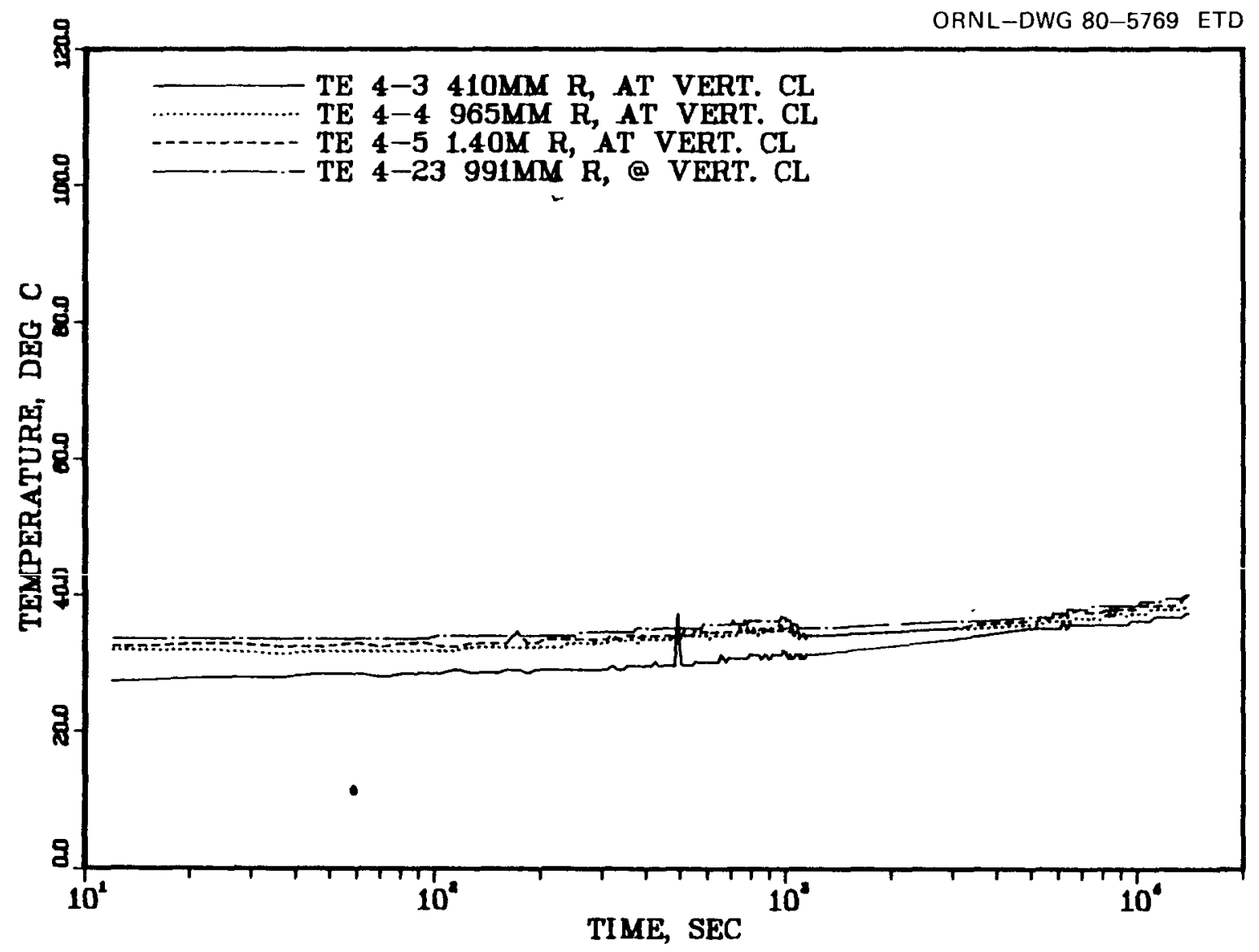

Fig. 47. Temperature measurements at vessel midplane-NSPP Test 204. 


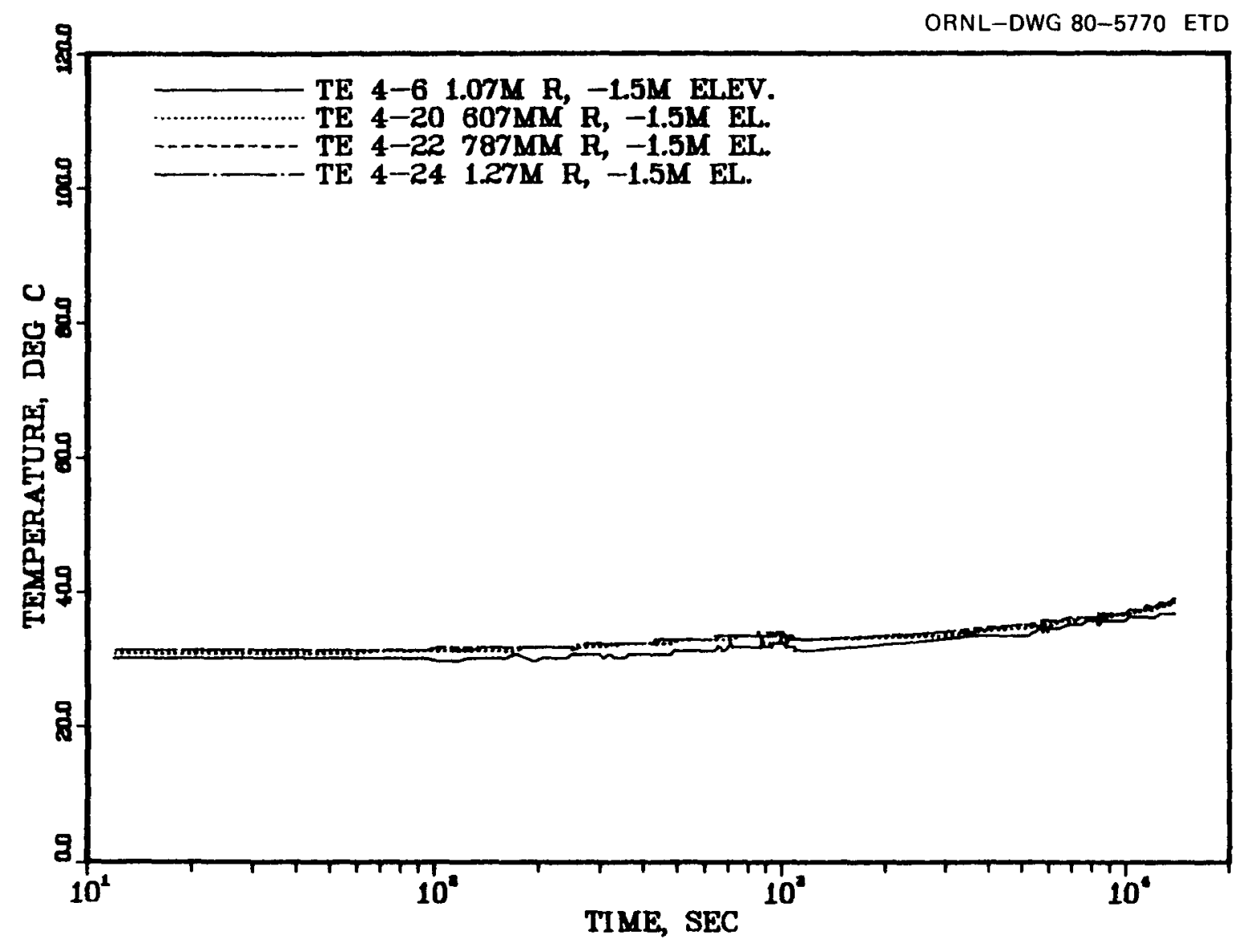

Fig. 48. Temperature measurements at $1.5 \mathrm{~m}$ below vessel midplane-NSPP Test 204. 


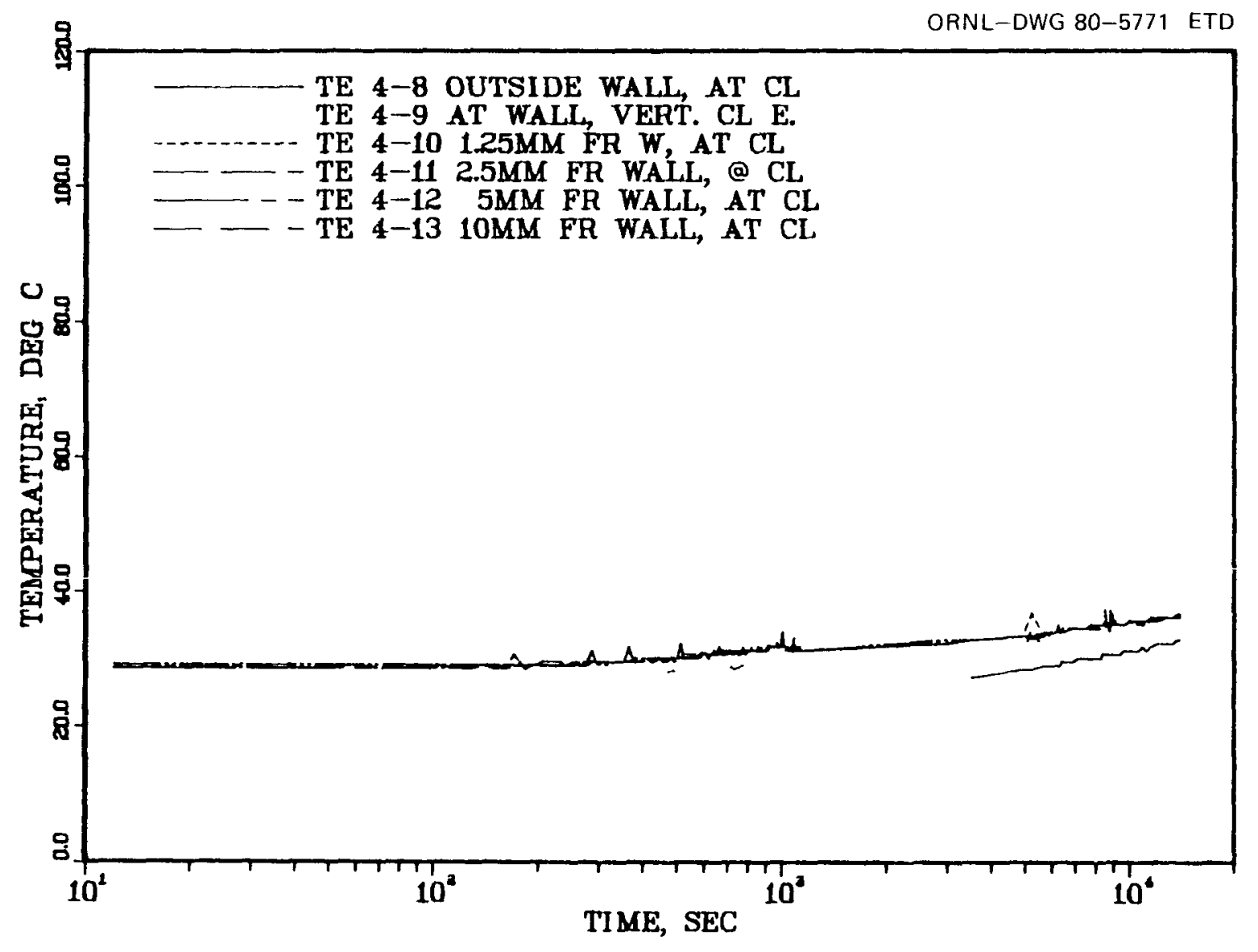

Fig 49 Temperature measurements near the vessel wall at vessel midplane-NSPP Test 204 


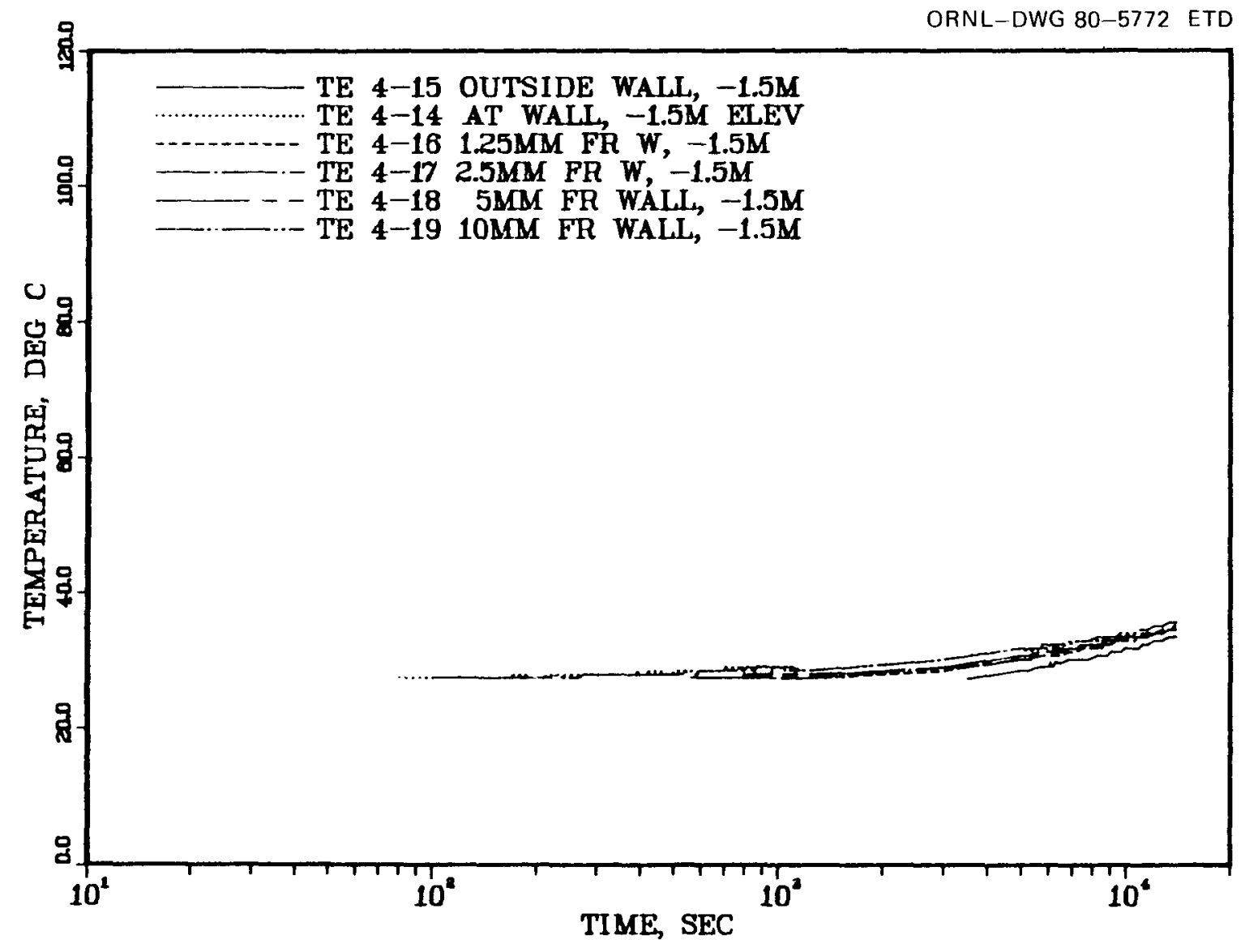

Fig. 50. Temperature measurements near the vessel wall at $1.5 \mathrm{~m}$ below vessel midplane-NSPP Test 204. 


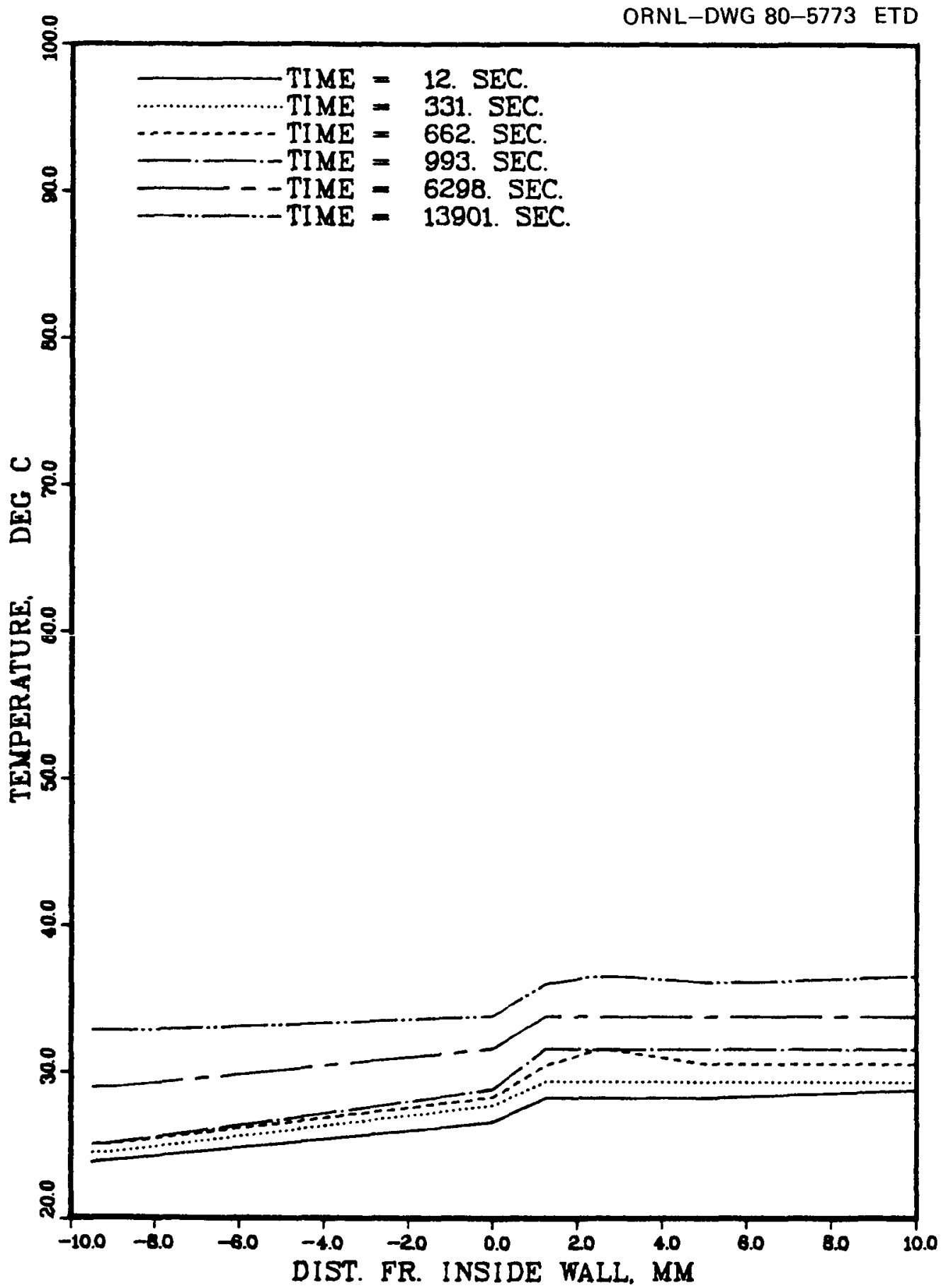

Fig. 51. Temperature profile near the vessel wall midplane for various times after start of aerosol generation (note that the diatance is measured from the inside wall toward the center of the vessel)-NSPP Test 204. 


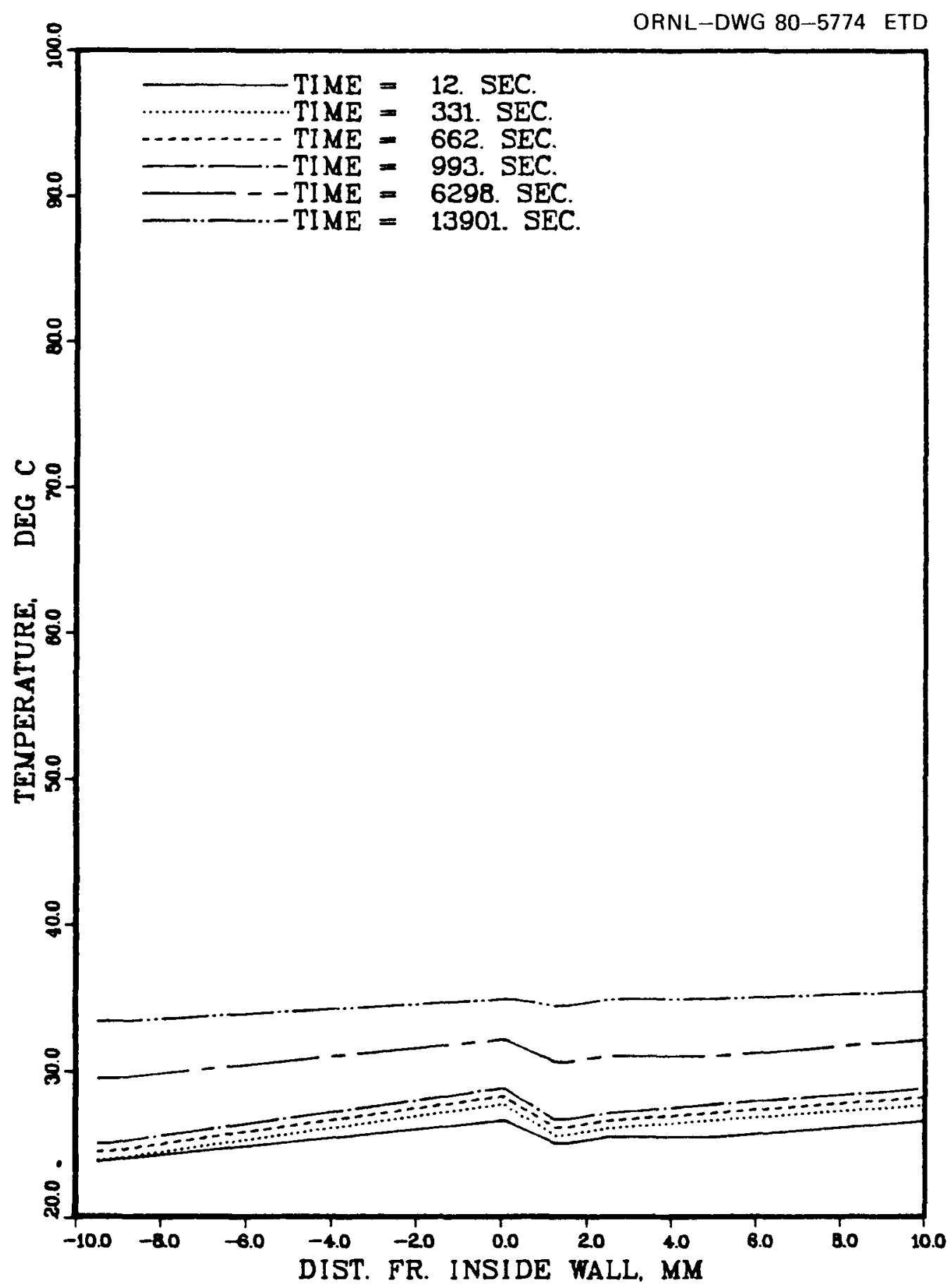

Fig. 52. Temperature profile near the vessel wall at $1.5 \mathrm{~m}$ below midplane for various times after start of aerosol generation-NSPP Test 204. 


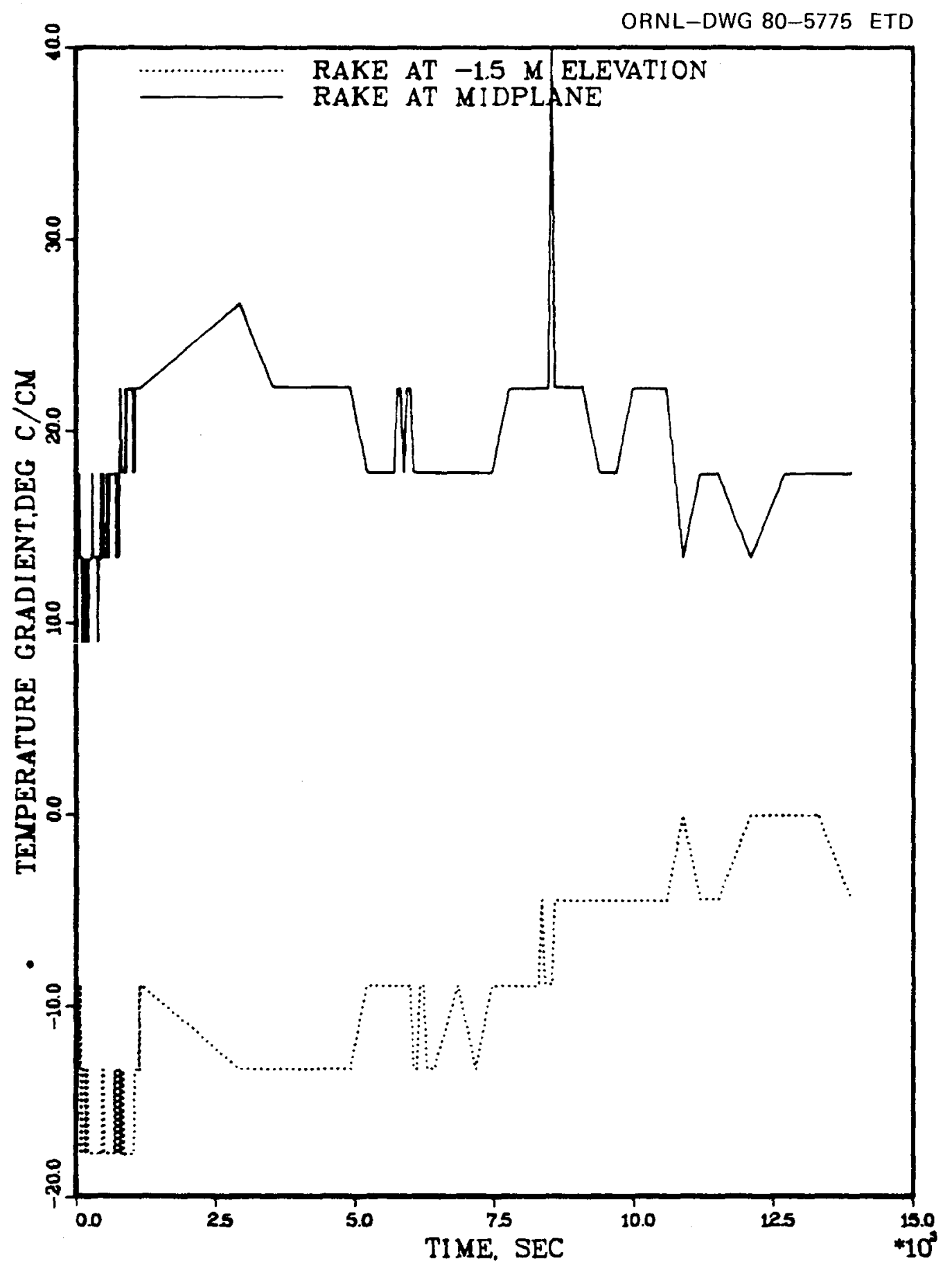

Fig. 53. Temperature gradient at the vessel wall for two elevations-NSPP Test 204. 


\subsection{Summary and Data Graphs for Test 205}

\section{Aerosol source}

Test aerosol used

$\mathrm{U}_{3} \mathrm{O}_{8}$

Aerosol generator

Plasma torch

Duration of aerosol generation

5 min

Vessel atmosphere prior to aerosol generation

Oxygen level

$21 \%$

Relative humidity

$<20 \%$

Temperature

Ambient

Pressure

Ambient

Duration of test operations

$48 \mathrm{~h}$

\section{Aerosol parameters measured and figure number}

Mass concentration of aerosol

Fig 54

Aerosol fallout rate

Fig 55

Aerosol plateout rate

Fig 56

Cumulative mass fallout and plateout

Fig 57

Aerosol particle size

Table 6

\section{System parameters measured and figure number}

Vessel atmosphere pressure

Fig 58

Vessel atmosphere temperatures

Figs 59-61

Thermal gradients at vessel wall

Figs 62-66

\section{Posttest results}

Maximum aerosol concentration achieved

$4 \mu \mathrm{g} / \mathrm{cm}^{3}$

Aerosol distribution at end of test

Sttll suspended in vessel atmosphere

$<002 \%$

Plated onto internal surfaces

$563 \%$

Settled onto vessel floor

$437 \%$

Table 6. Andersen impactor data-Test 205

\begin{tabular}{|c|c|c|c|c|c|c|c|}
\hline \multirow{2}{*}{$\begin{array}{l}\text { Aerodynamic } \\
\text { mass median } \\
\text { diameter } \\
(\mu \mathrm{m})\end{array}$} & \multicolumn{7}{|c|}{ Sample No ${ }^{\circ}$} \\
\hline & $\begin{array}{c}1 \\
(13 \mathrm{~min})\end{array}$ & $\begin{array}{c}2 \\
(36 \mathrm{~m} ! \mathrm{n})\end{array}$ & $\begin{array}{c}3 \\
(79 \mathrm{~mm})\end{array}$ & $\begin{array}{c}4 \\
(182 \mathrm{~min})\end{array}$ & $\begin{array}{c}5 \\
(345 \mathrm{~min})\end{array}$ & $\begin{array}{c}6 \\
(549 \mathrm{~min})\end{array}$ & $\begin{array}{c}7 \\
(1531 \mathrm{~min})\end{array}$ \\
\hline 137 & 988 & 971 & 979 & 742 & 790 & 843 & 857 \\
\hline 85 & 971 & 934 & 951 & 572 & 690 & 762 & 776 \\
\hline 58 & 924 & 807 & 829 & 458 & 518 & 654 & 646 \\
\hline 40 & 818 & 651 & 712 & 361 & 422 & 564 & 536 \\
\hline 25 & 606 & 434 & 484 & 259 & 310 & 436 & 393 \\
\hline 13 & 279 & 188 & 169 & 145 & 136 & 195 & 174 \\
\hline 078 & 102 & 62 & 31 & 65 & 27 & 66 & 62 \\
\hline 053 & 28 & 06 & 07 & 06 & 14 & 18 & 17 \\
\hline
\end{tabular}

${ }^{a}$ Percent of mass associated with diameters smaller than indicated size 
ORNL-DWG 80-5776 ETD

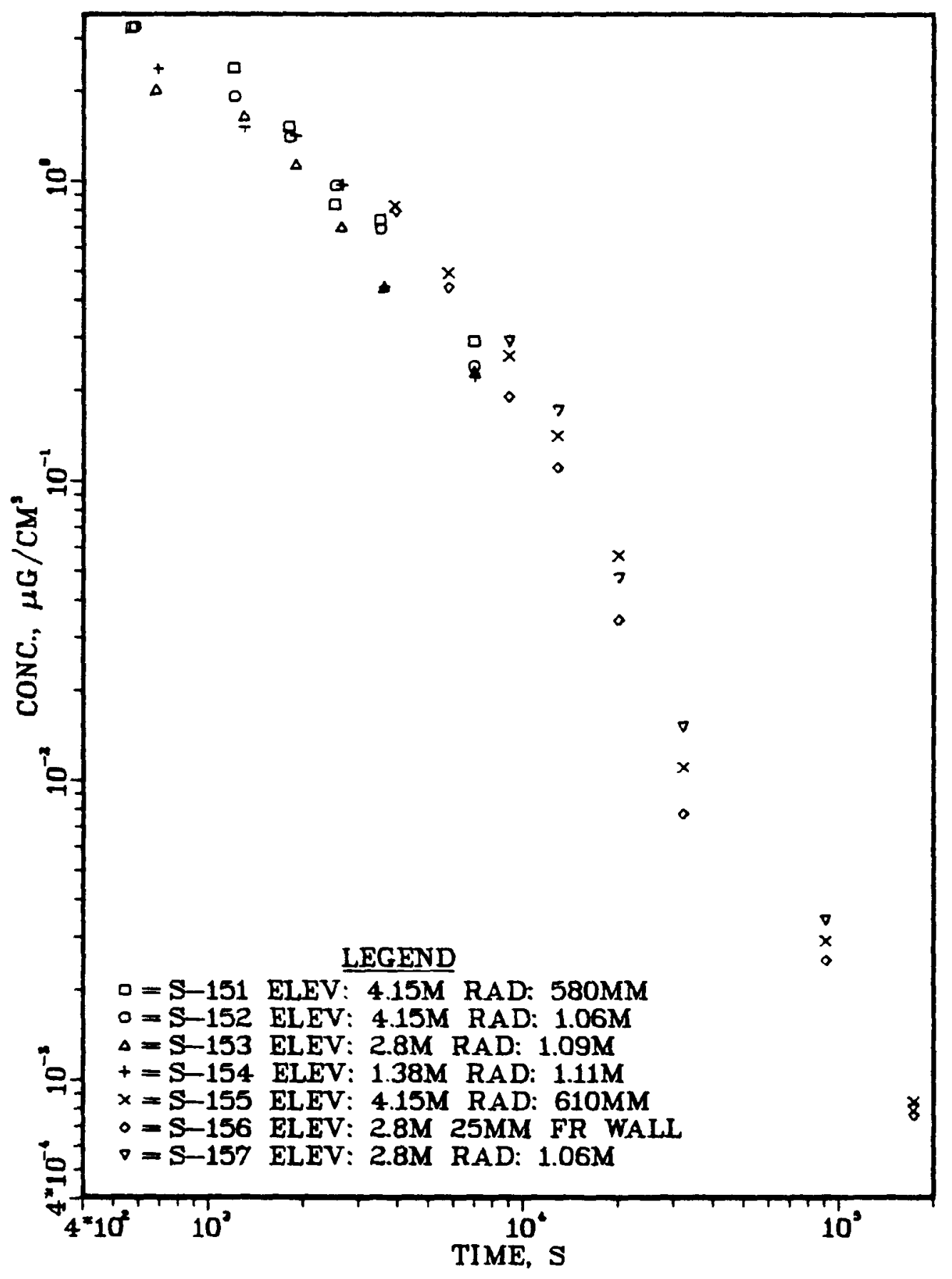

Fig. 54. Aerosol mass concentrations vs time-NSPP Test 205. 


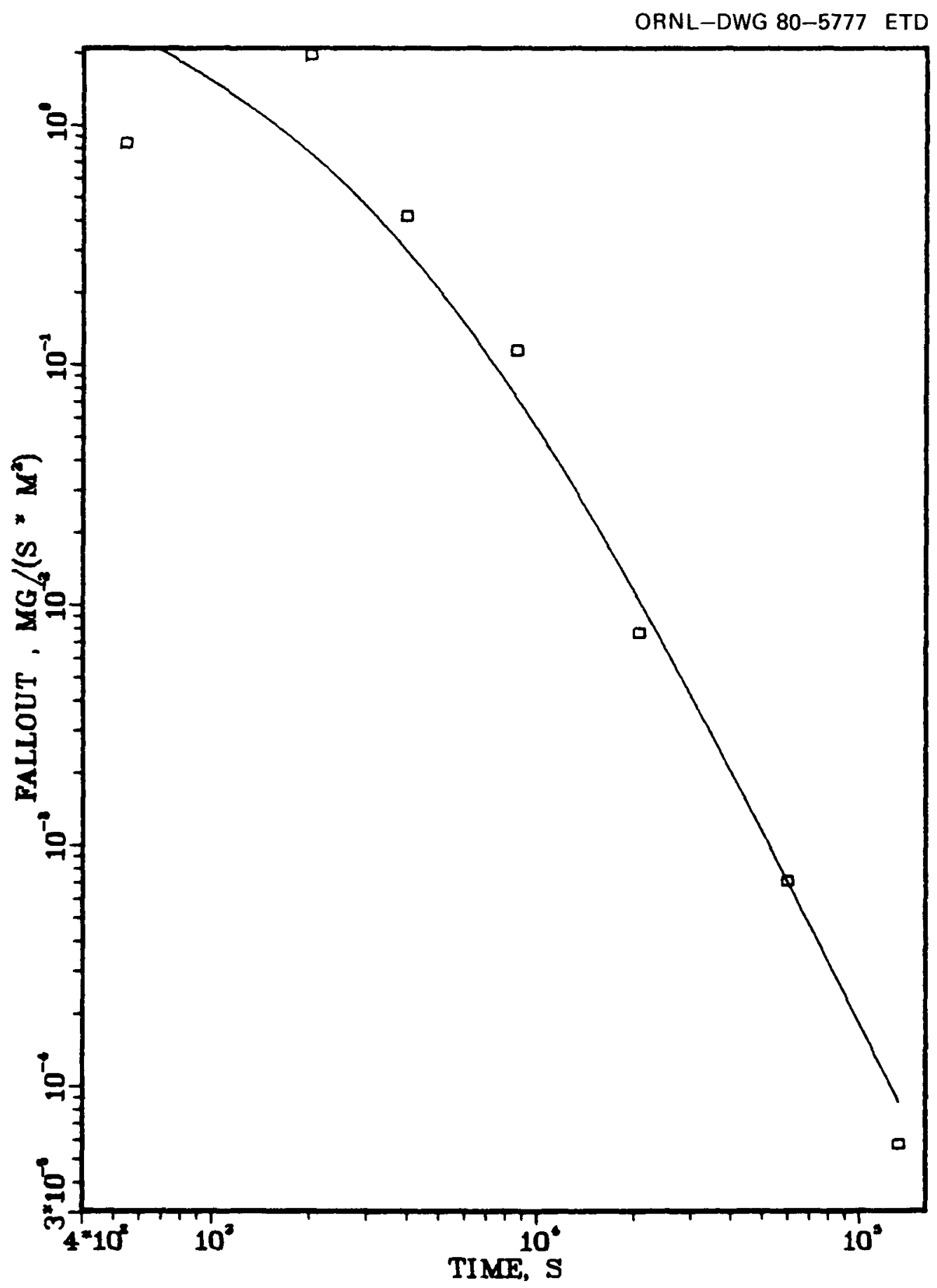

Fig. 55. Fallout rate vs time-NSPP Test 205. 


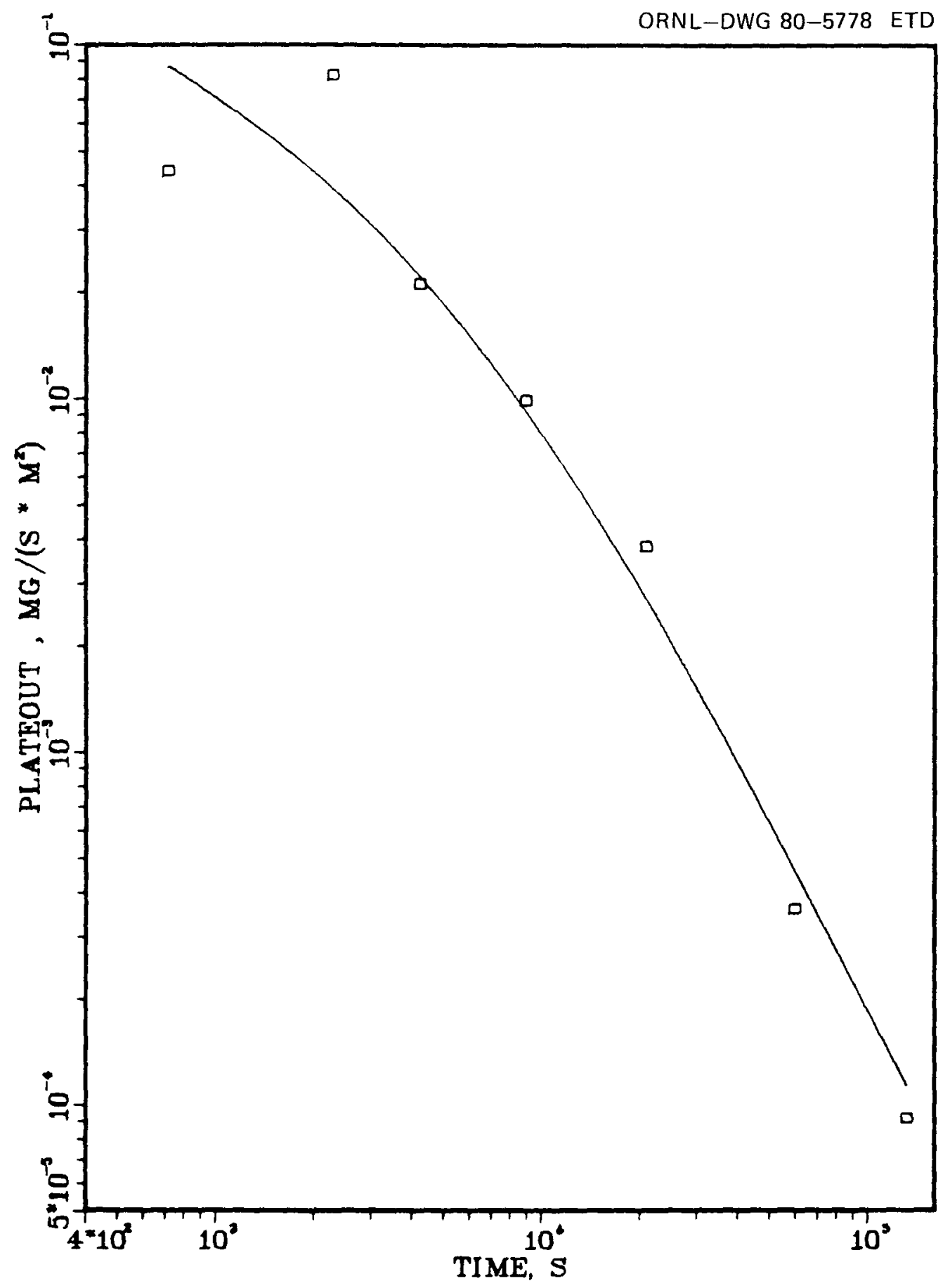

Fig. 56. Plateout rate vs time-NSPP Test 205. 


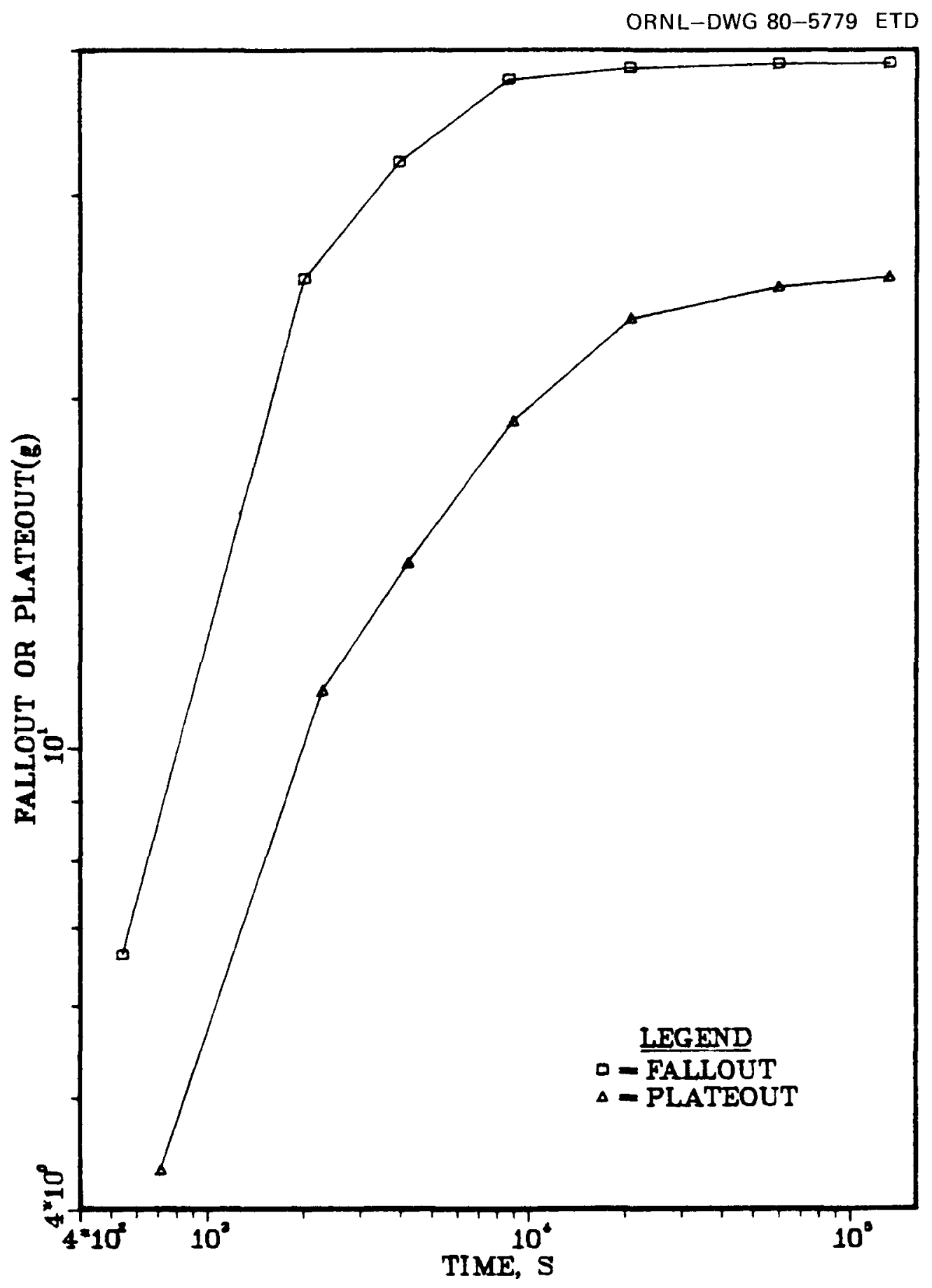

Fig. 57. Cumulative fallout and plateout mass vs time-NSPP Test 205. 


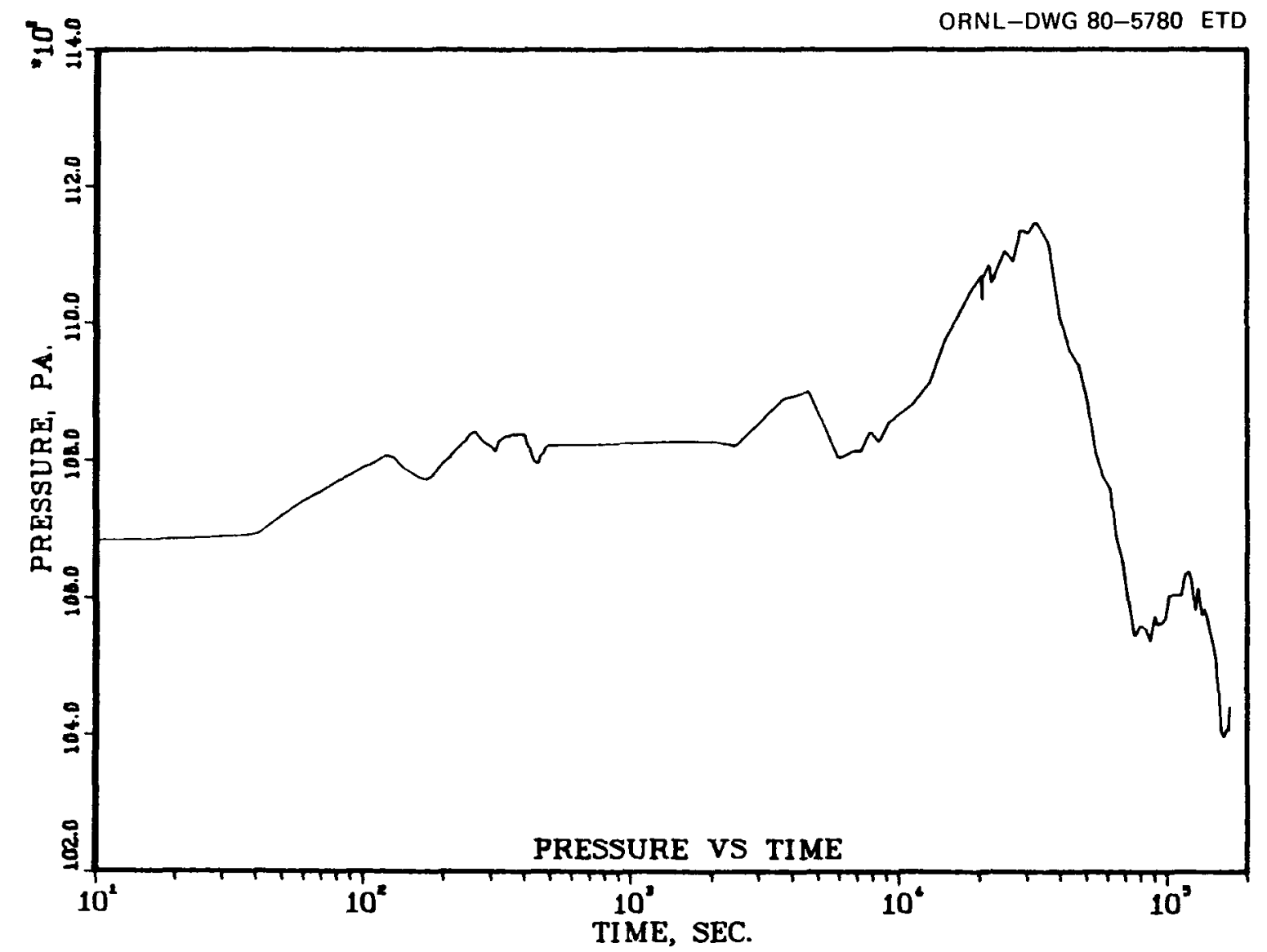

Fig. 58. In-vessel pressure vs time-NSPP Test 205. 


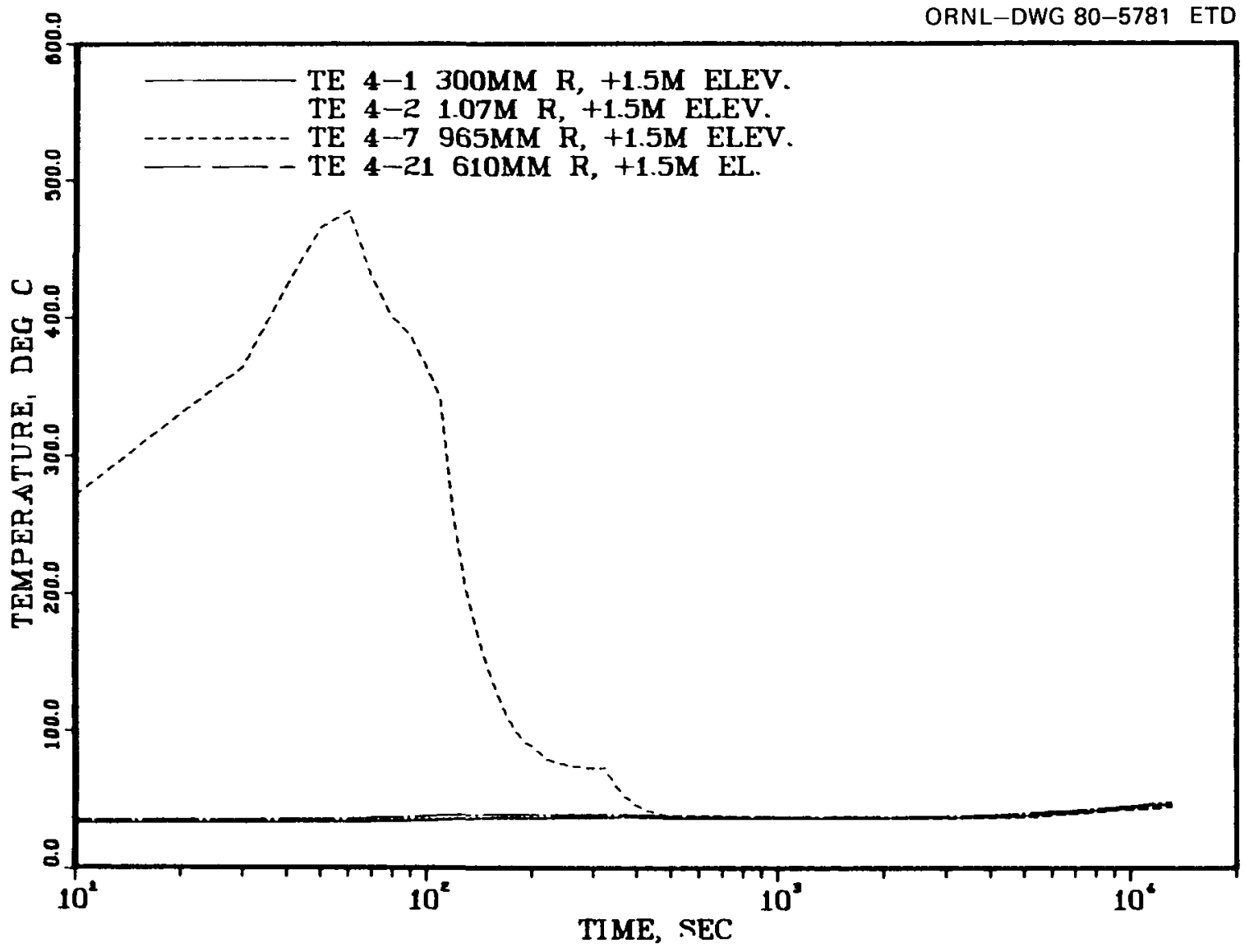

Fig. 59. Temperature measurements at $1.5 \mathrm{~m}$ above vessel midplane-NSPP Test 205. 


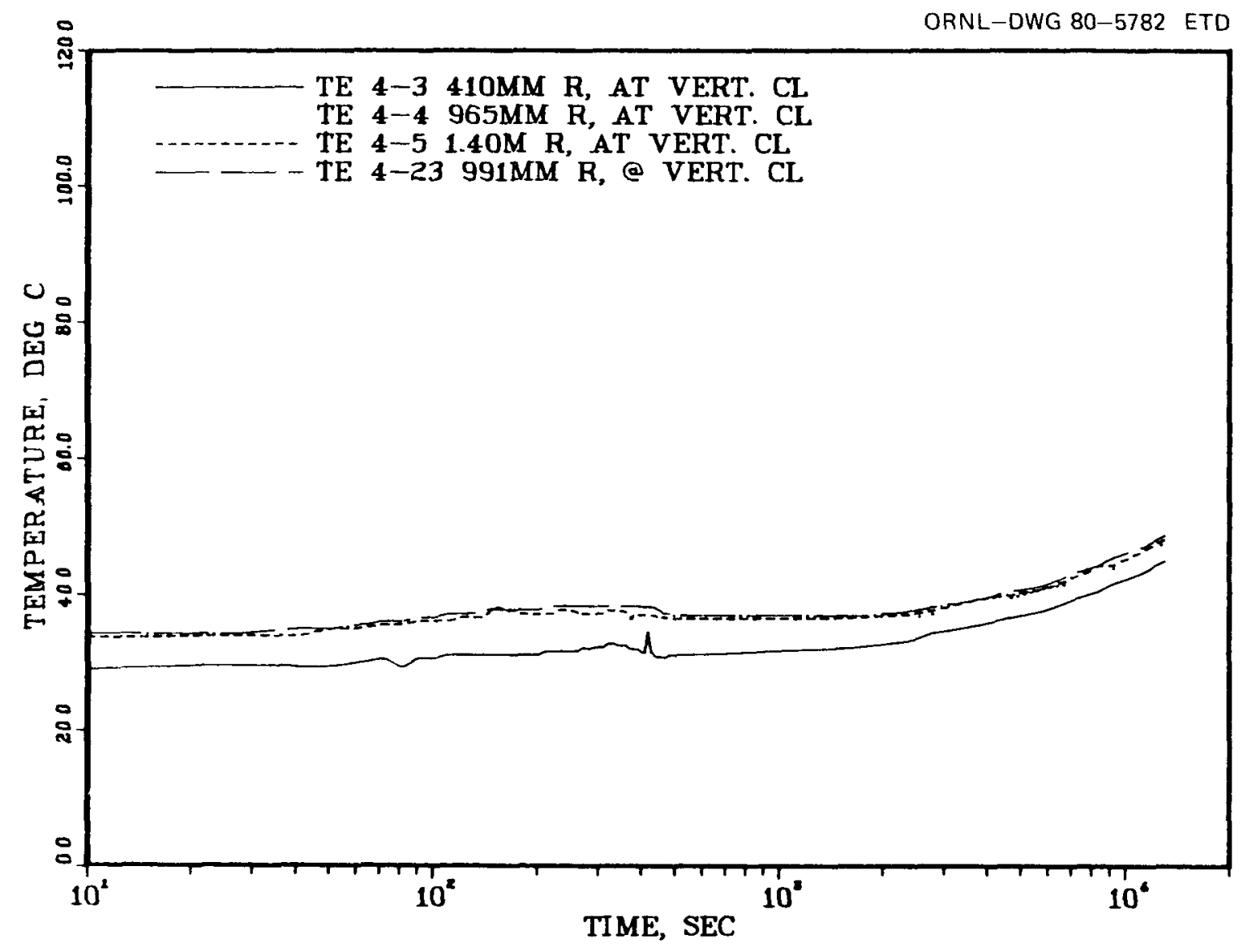

Fig. 60. Temperature measurements at vessel midplane-NSPP Test 205. 


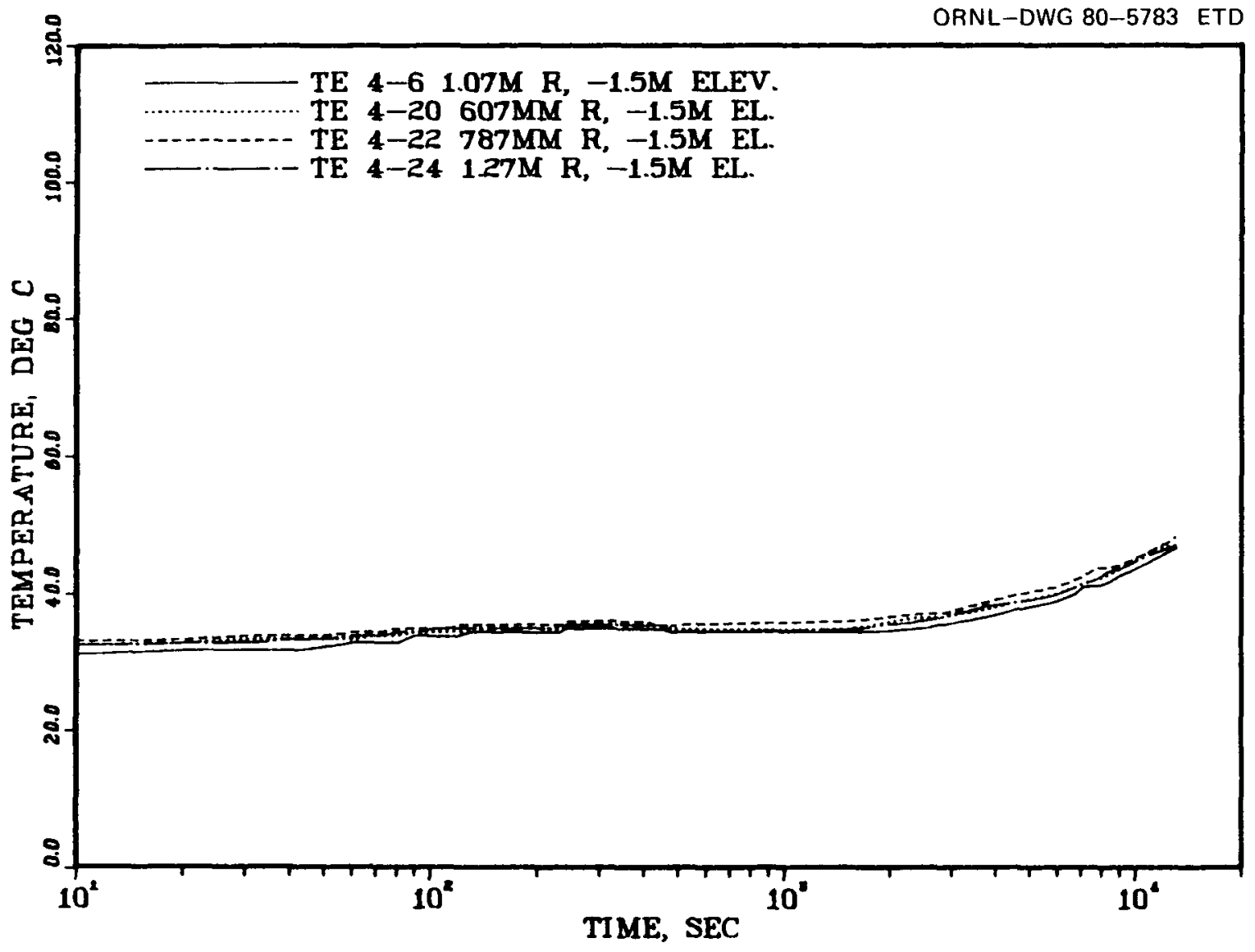

Fig. 61. Temperature measurements at $1.5 \mathrm{~m}$ below vessel midplane-NSPP Test 205 . 


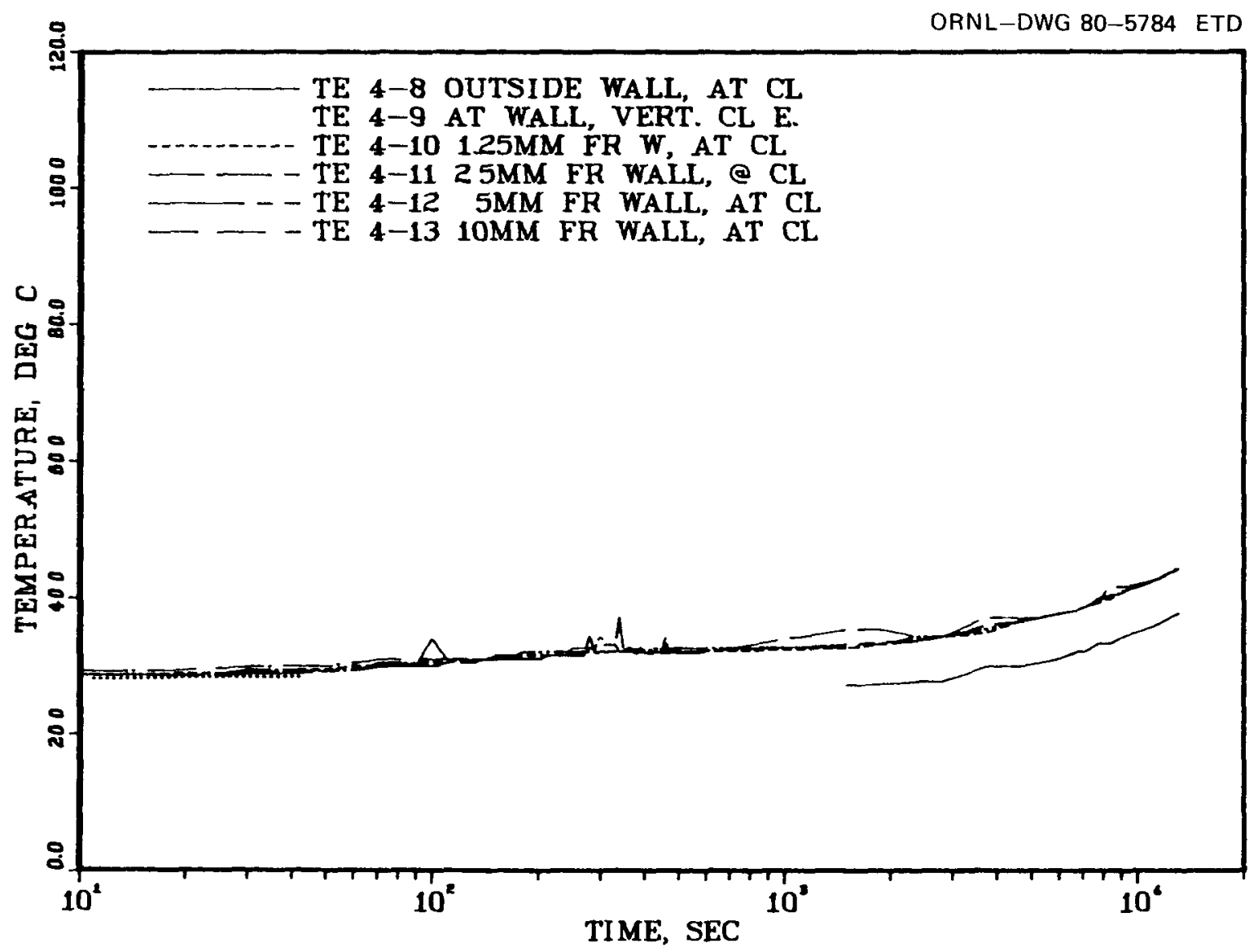

Fig. 62. Temperature measurements near the vessel wall at vessel midplane-NSPP Test 205. 


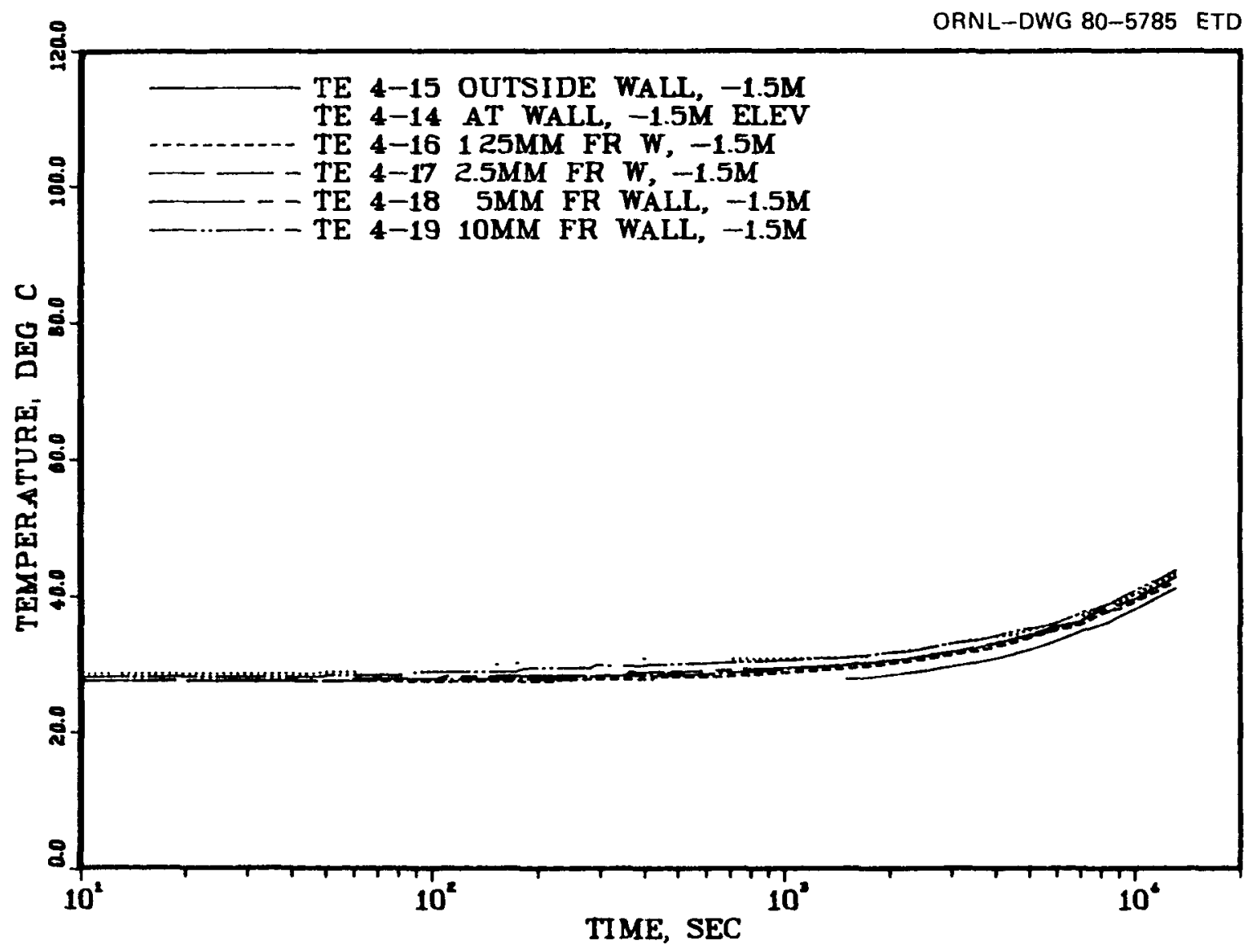

Fig. 63. Temperature measurements near the vessel wall at $1.5 \mathrm{~m}$ below vessel midplane-NSPP Test 205 . 


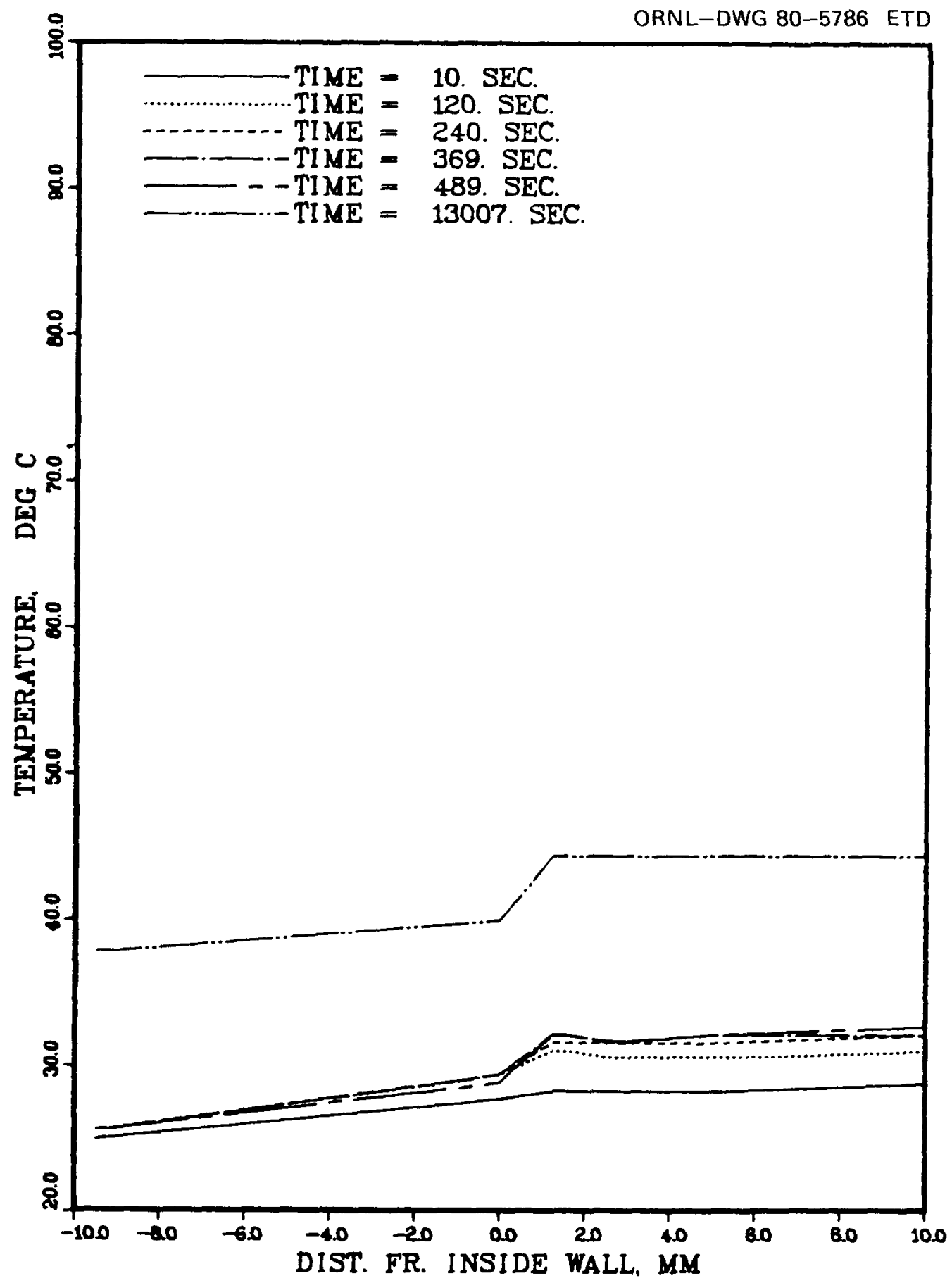

Fig. 64. Temperature profile near the vessel wall at midplane for various times after start of aerosol generation (note that the distance is measured from the inside wall toward the center of the vessel)-NSPP Test 205. 


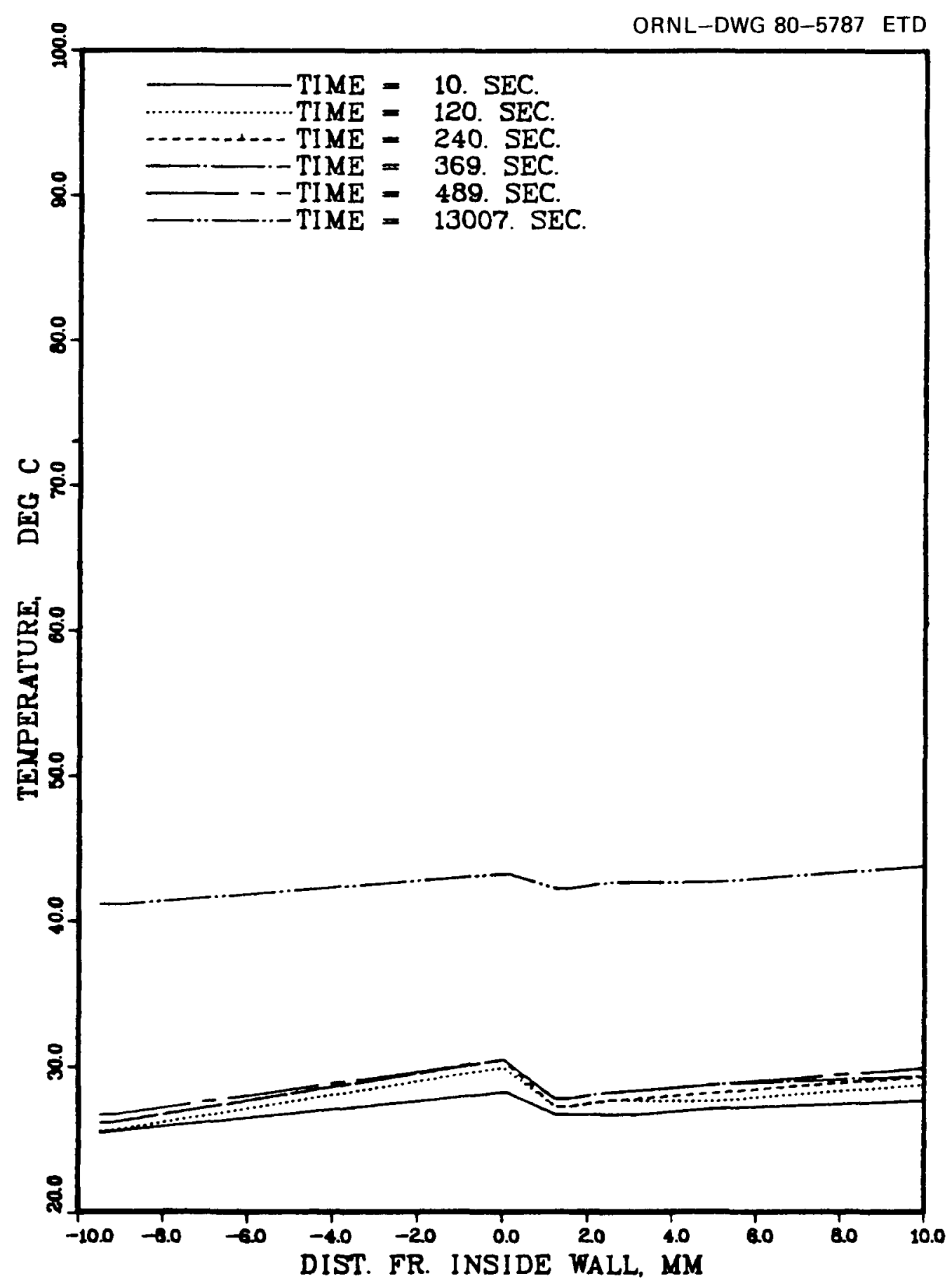

Fig. 65. Temperature profile near the vessel wall at $1.5 \mathrm{~m}$ below midplane for various times after start of aerosol generation-NSPP Test 205. 


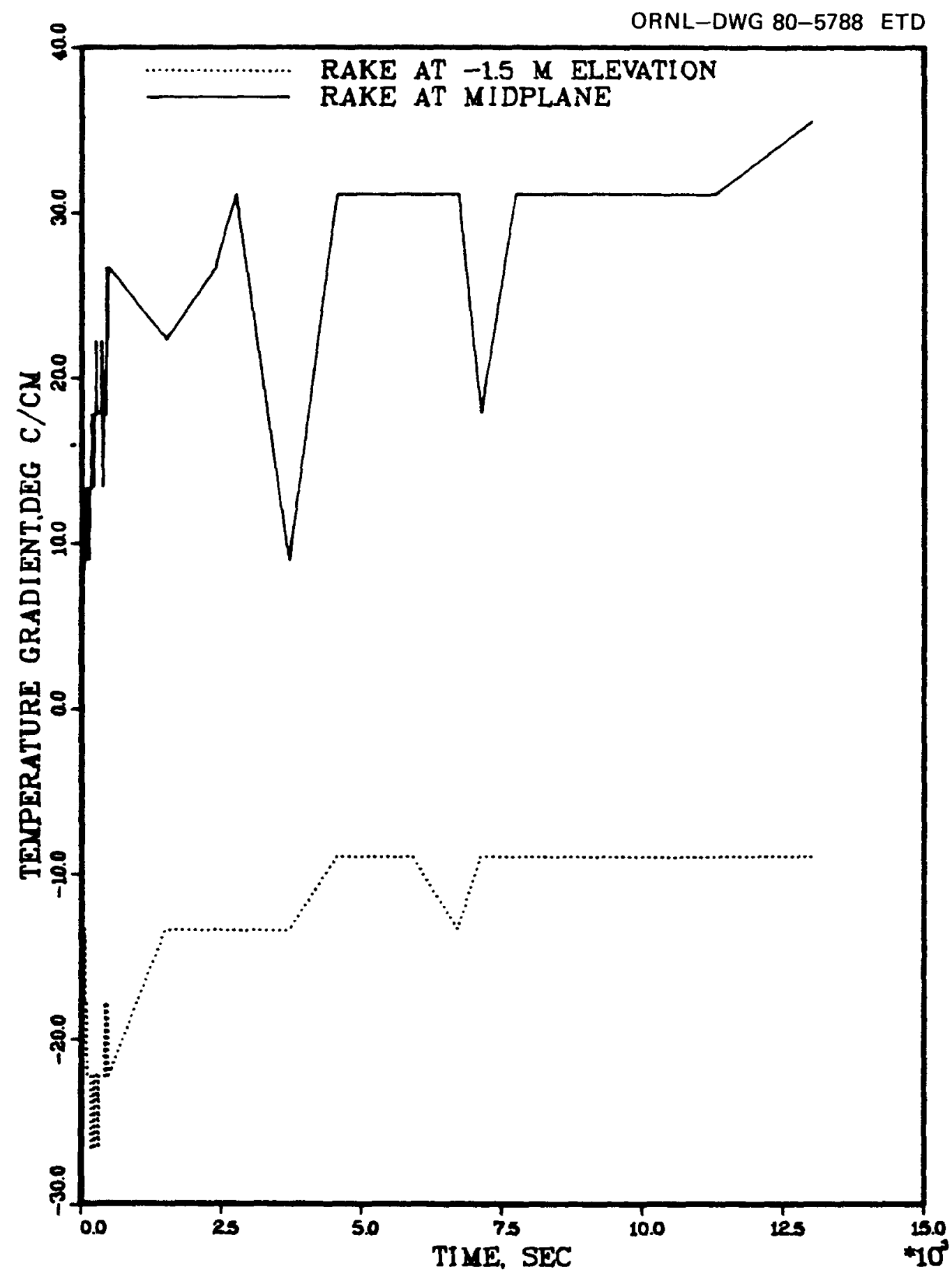

Fig. 66. Temperature gradient at the vessel wall for two elevations-NSPP Test 205. 


\subsection{Summary and Data Graphs for Test 206}

Aerosol source

Test aerosol used

$\mathrm{U}_{3} \mathrm{O}_{8}$

Aerosol generator

Plasma torch

Duration of aerosol generation

$93 \mathrm{~min}$

Vessel atmosphere prior to aerosol generation

Oxygen level

$21 \%$

Relative humidity

$<20 \%$

Temperature

Ambient

Pressure

Ambien

Duration of test operations

$48 \mathrm{~h}$

Aerosol parameters measured and figure number

Mass concentration of aerosol

Fig 67

Aerosol fallout rate

Fig 68

Aerosol plateout rate

Fig 69

Cumulative mass fallout and plateout

Fig 70

Aerosol partıcle size

Table 7

System parameters measured and figure number

Vessel atmosphere pressure

Fig 71

Vessel atmosphere temperatures

Figs 72-74

Thermal gradients at vessel wall

Figs 75-79

\section{Posttest results}

Maxımum aerosol concentration achieved

$56 \mu \mathrm{g} / \mathrm{cm}^{3}$

Aerosol distribution at end of test

Still suspended in vessel atmosphere

Plated onto internal surfaces

$<001 \%$

Settled onto vessel floor

$35 \%$

$65 \%$

Table 7. Andersen impactor data-Test 206

\begin{tabular}{|c|c|c|c|c|c|c|c|}
\hline \multirow{2}{*}{$\begin{array}{l}\text { Aerodynamic } \\
\text { mass median } \\
\text { diameter } \\
(\mu \mathrm{m})\end{array}$} & \multicolumn{7}{|c|}{ Sample $\mathrm{No}^{a}$} \\
\hline & $\begin{array}{c}1 \\
(17 \mathrm{~min})\end{array}$ & $\begin{array}{c}2 \\
(385 \mathrm{~m} ı)\end{array}$ & $\begin{array}{c}3 \\
(81 \mathrm{~min})\end{array}$ & ${ }^{4}(190 \mathrm{~min})$ & ${ }^{5}\left(345^{\mathrm{min}}\right)$ & $\begin{array}{c}6 \\
(504 \mathrm{~min})\end{array}$ & $\begin{array}{c}7^{b} \\
(1451 \mathrm{~min})\end{array}$ \\
\hline 137 & 940 & 957 & 966 & 981 & 993 & 989 & 786 \\
\hline 85 & 861 & 927 & 930 & 965 & 986 & 981 & 664 \\
\hline 58 & 774 & 835 & 813 & 895 & 970 & 960 & 583 \\
\hline 40 & 667 & 663 & 645 & 744 & 862 & 888 & 495 \\
\hline 25 & 518 & 444 & 403 & 444 & 554 & 609 & 429 \\
\hline 13 & 256 & 194 & 140 & 147 & 179 & 97 & 383 \\
\hline 078 & 77 & 38 & 38 & 18 & 18 & 32 & 346 \\
\hline 053 & 11 & 02 & 02 & 05 & 05 & 12 & 287 \\
\hline
\end{tabular}

${ }^{a}$ Percent of mass associated with diameters smaller than indicated size

${ }^{b}$ Total $\mathrm{U}_{3} \mathrm{O}_{8}$ found in impactor was $52 \mu \mathrm{g}$, insufficient for accurate sizing 


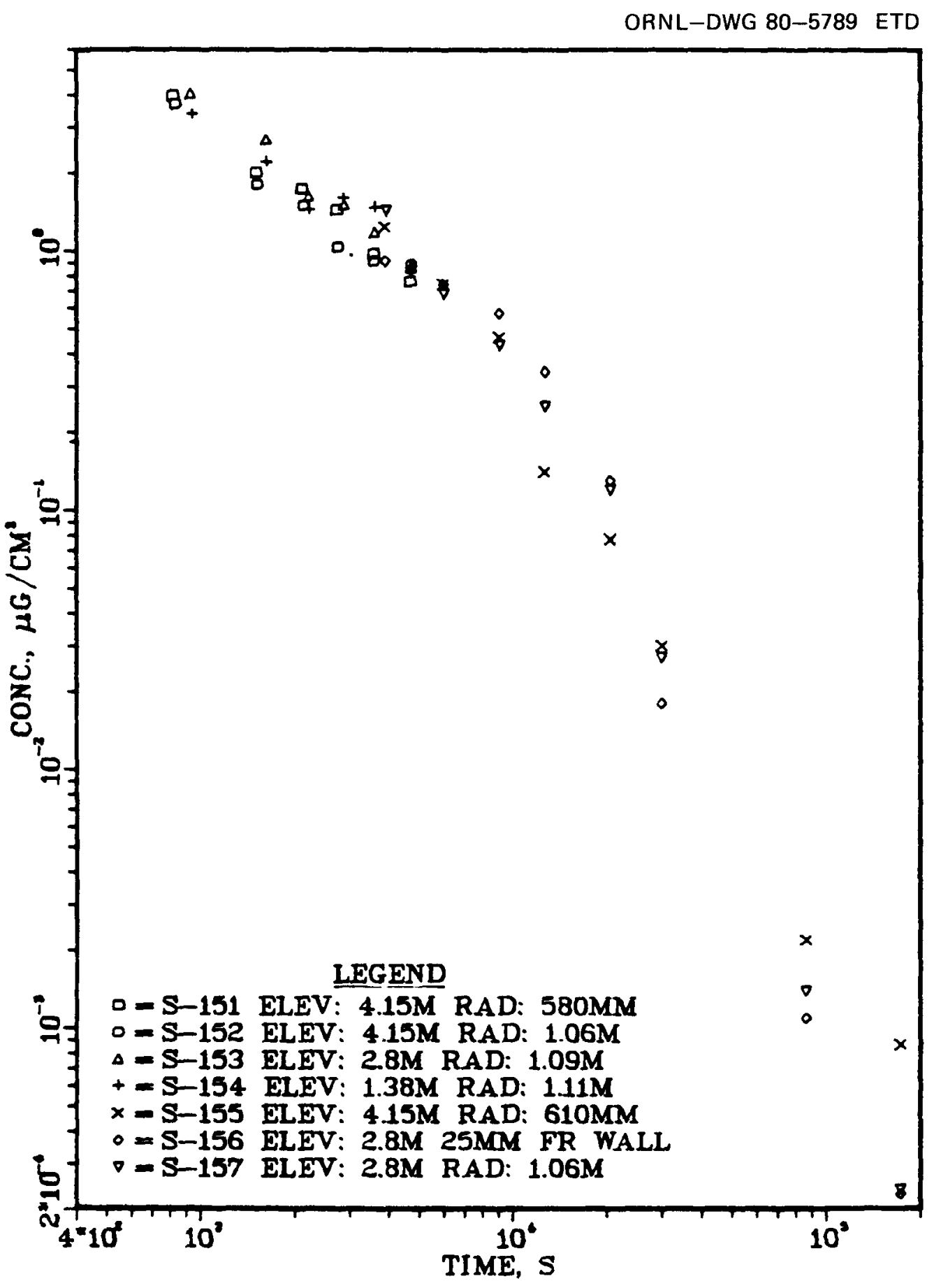

Fig. 67. Aerosol mass concentrations vs time-NSPP Test 206. 


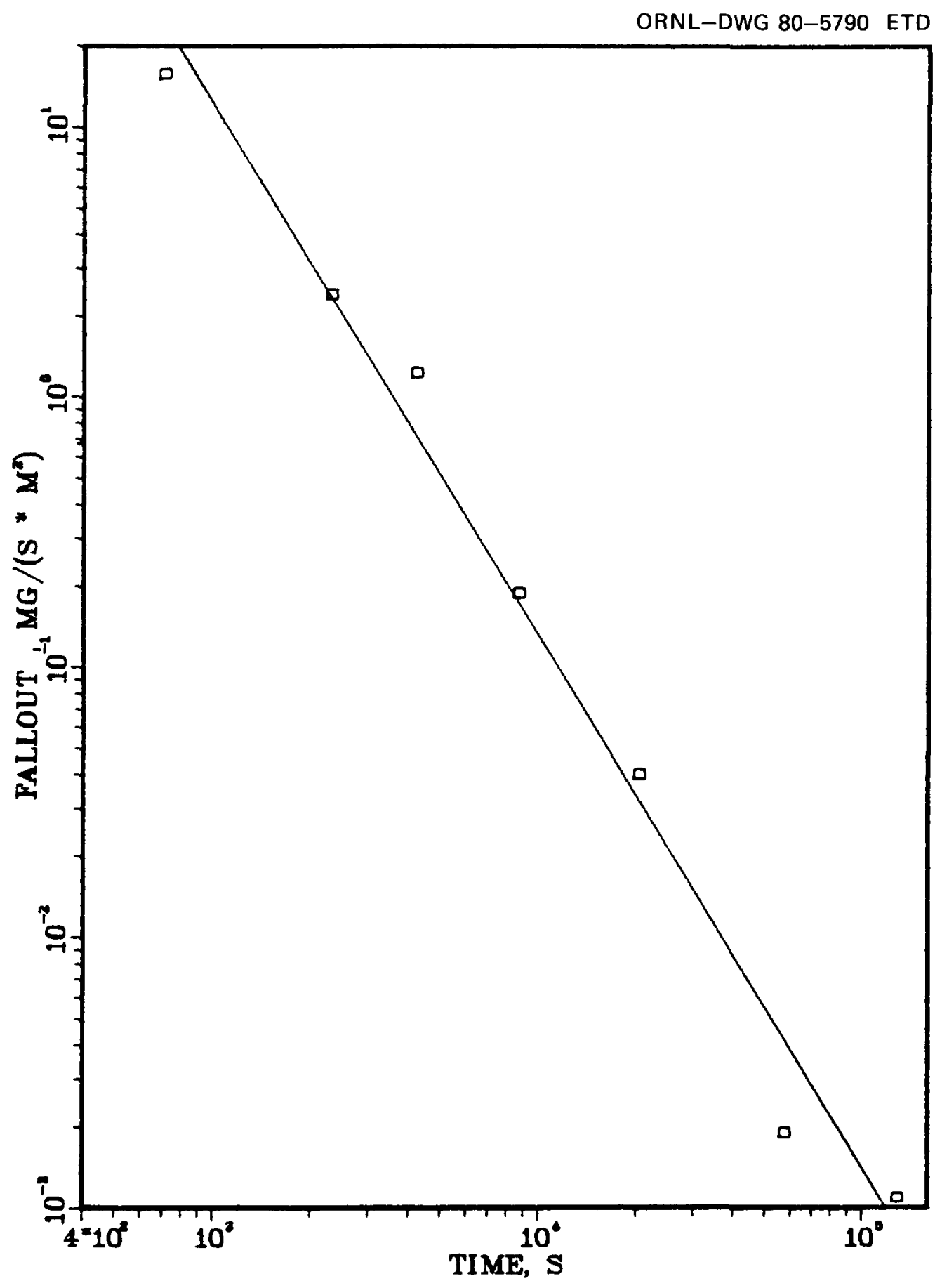

Fig. 68. Fallout rate vs time-NSPP Test 206. 


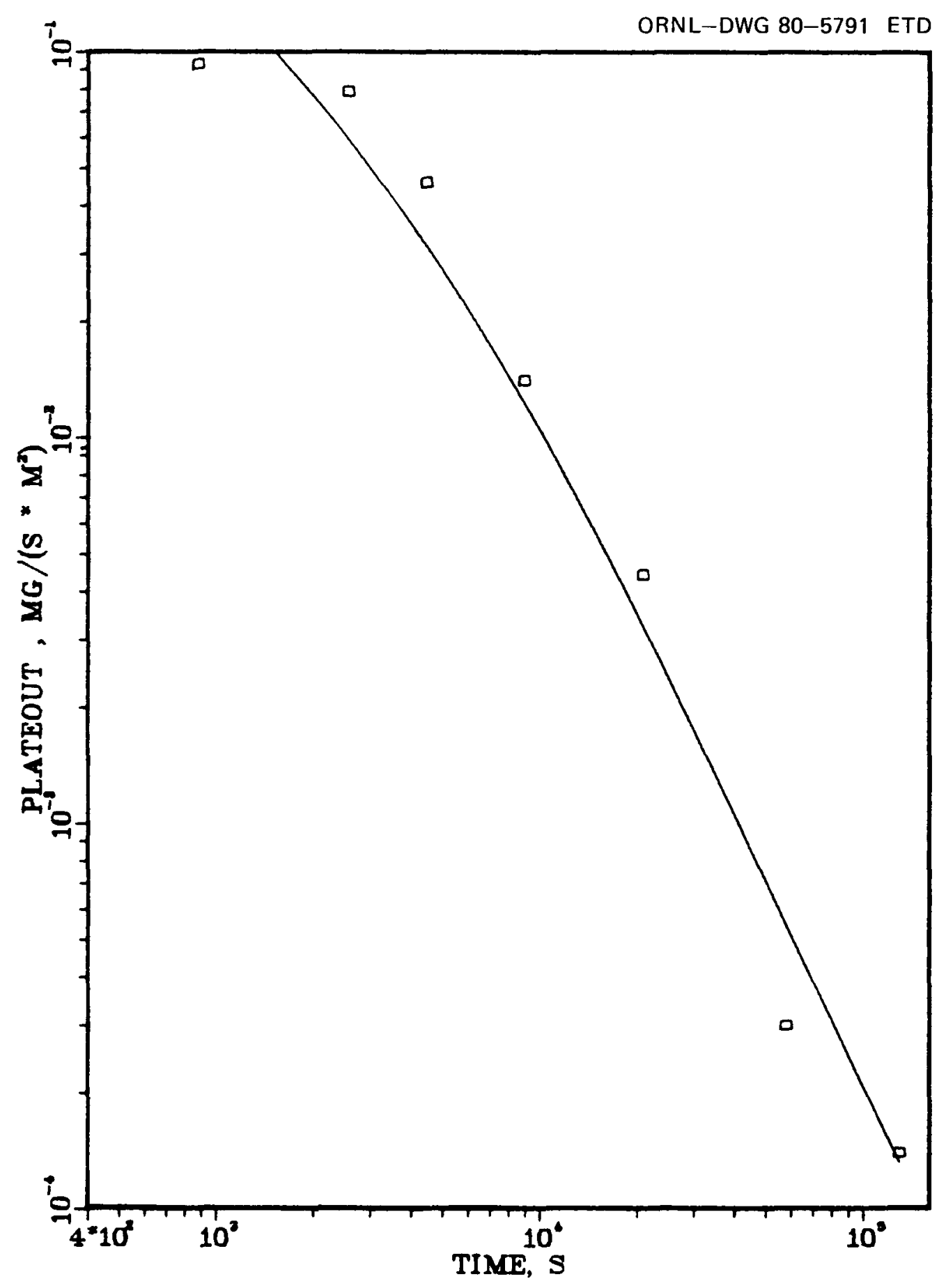

Fig. 69. Plateout rate vs time-NSPP Test 206. 


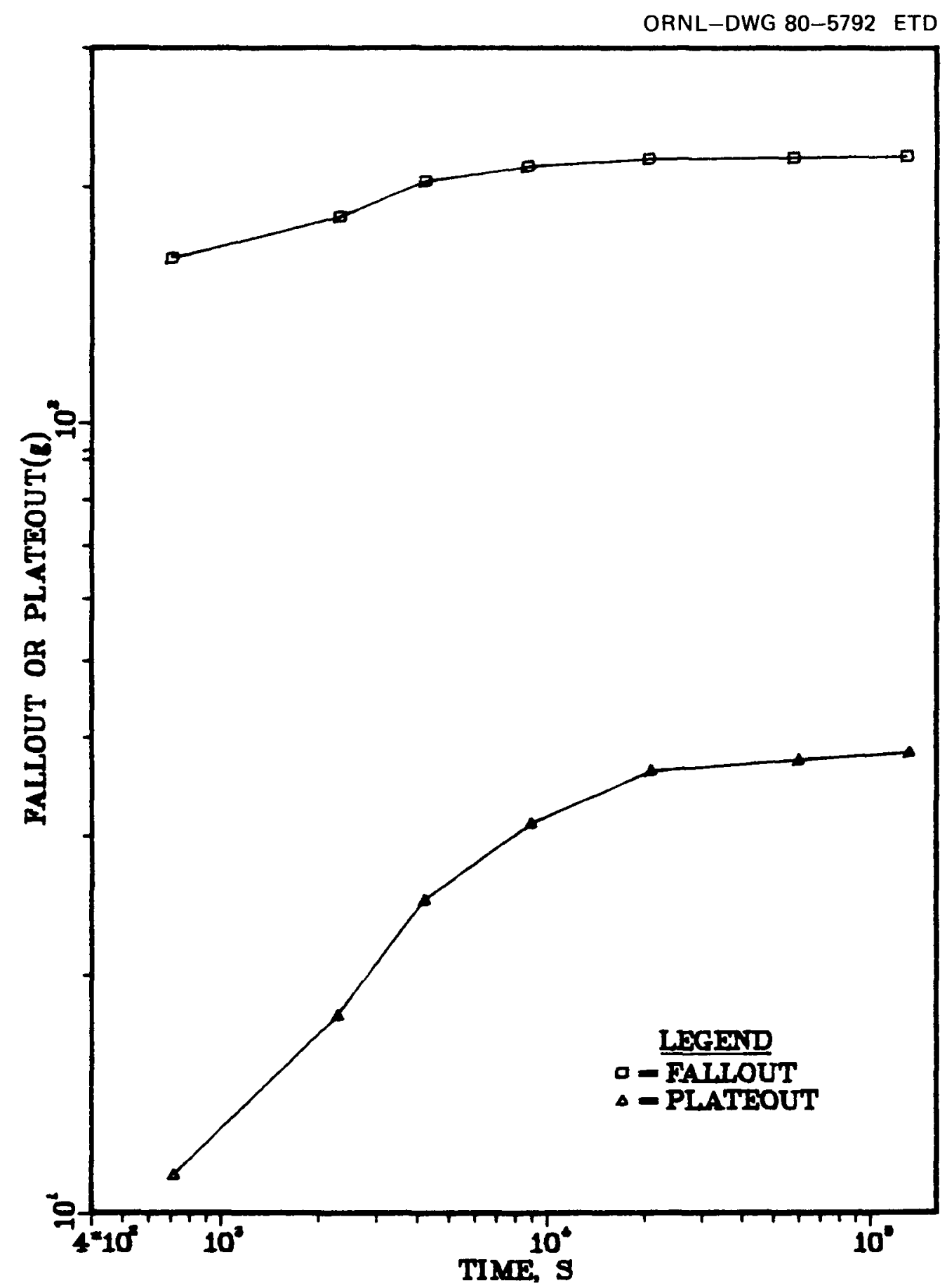

Fig. 70. Cumulative fallout and plateout mass vs time-NSPP Test 206. 


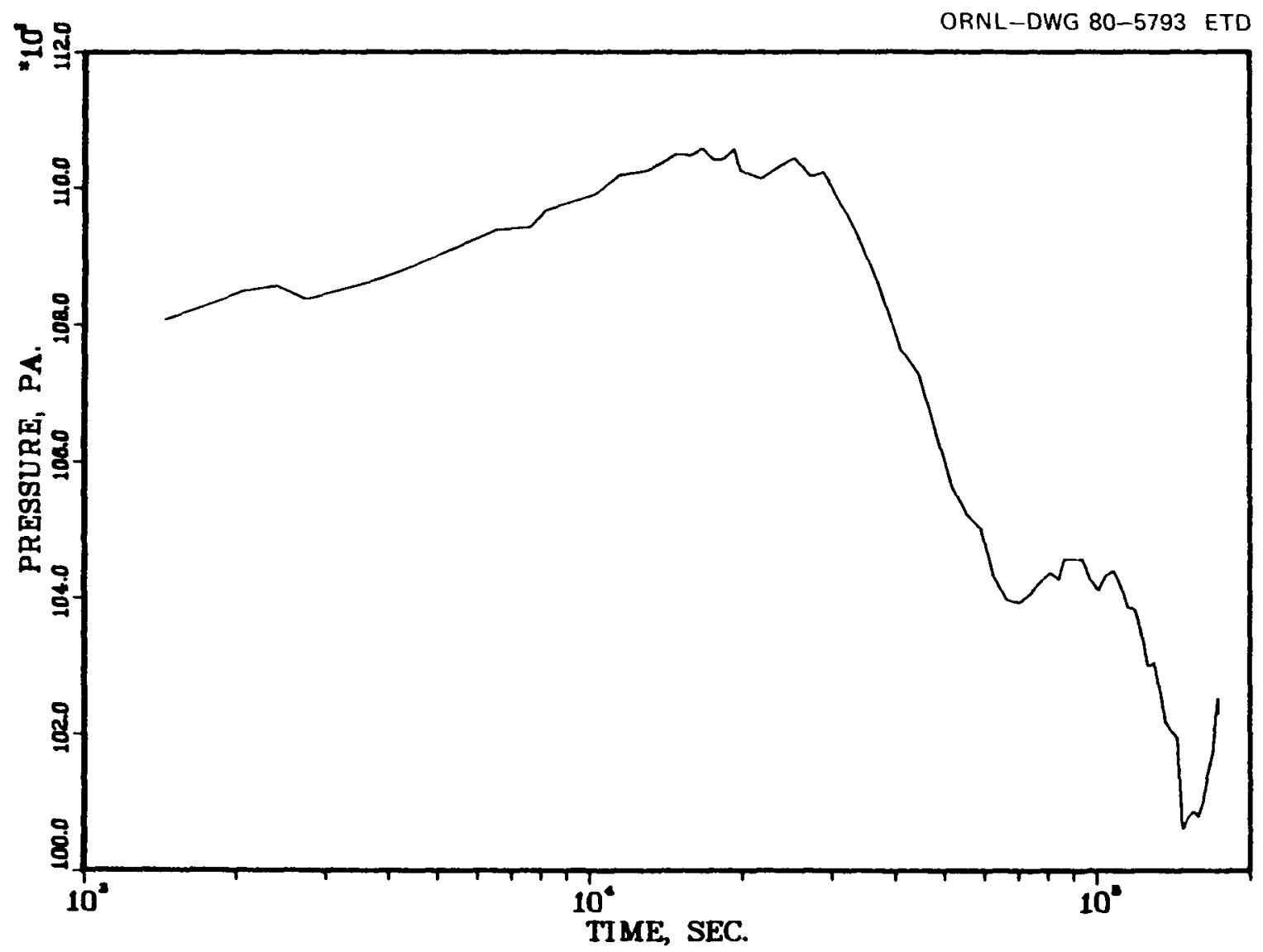

Fig. 71. In-vessel pressure vs time-NSPP Test 206. 


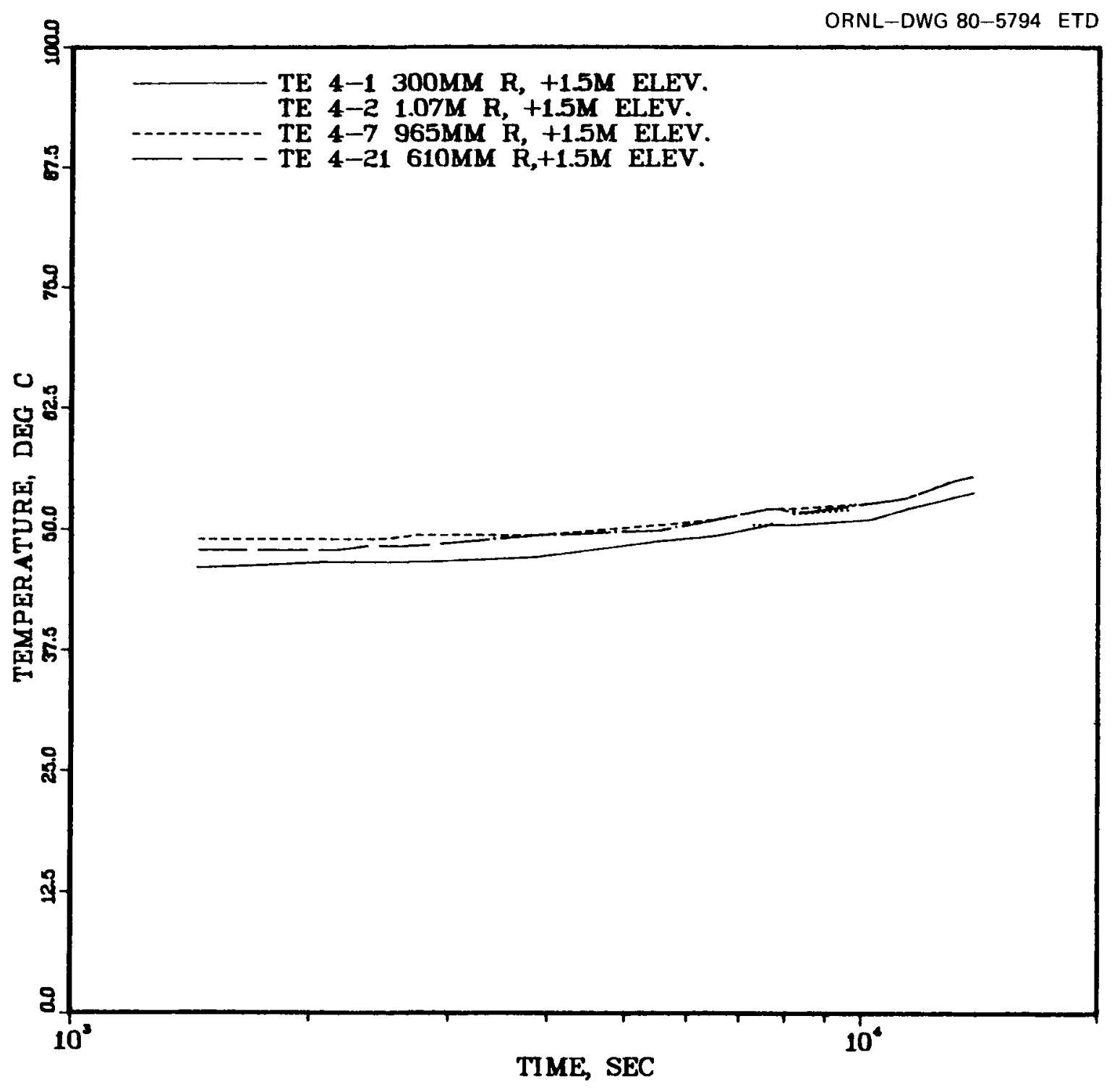

Fig. 72. Temperature measurements at $1.5 \mathrm{~m}$ above vessel midplane-NSPP Test 206 


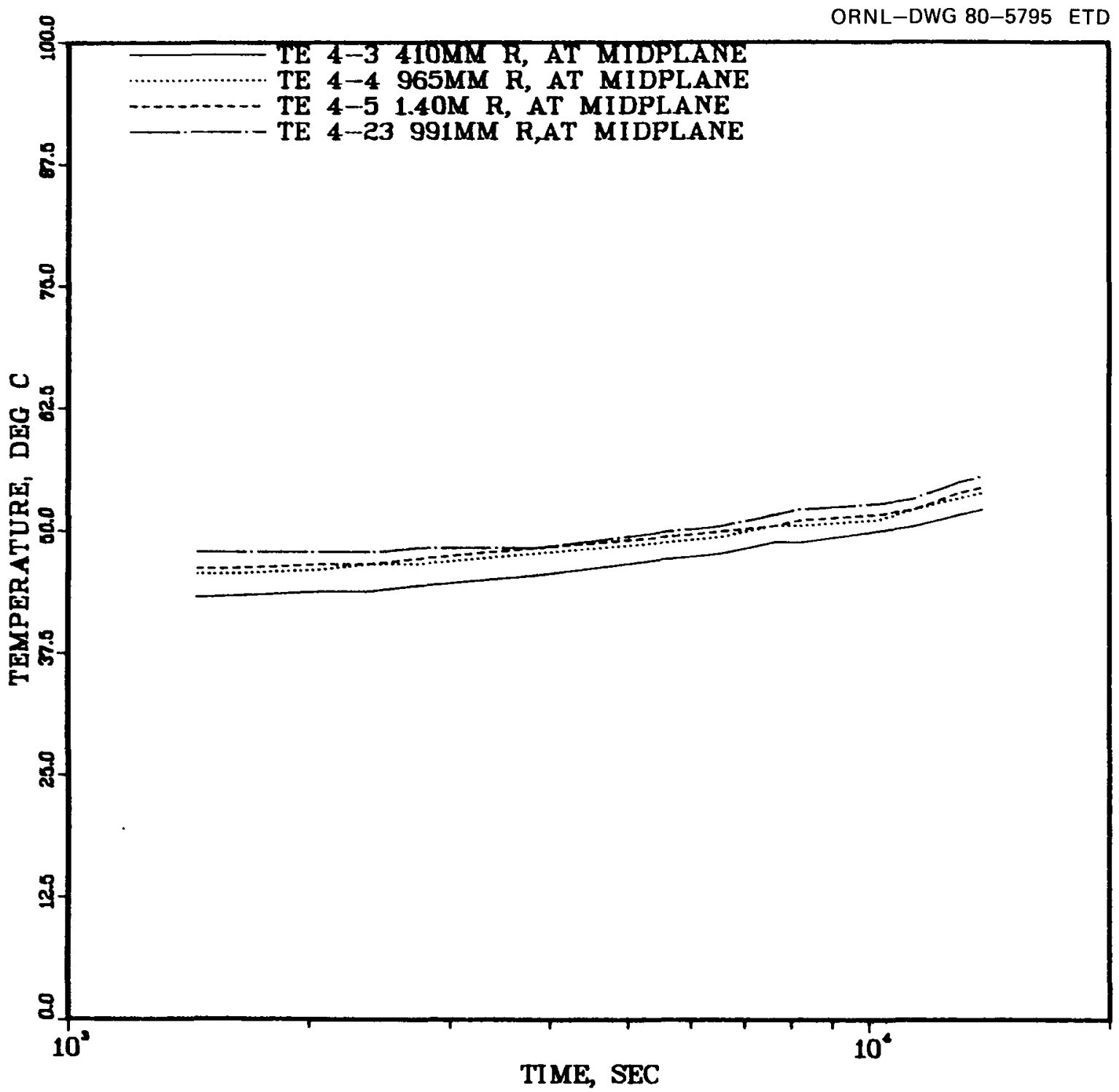

Fig. 73. Temperature measurements at vessel midplane-NSPP Test 206. 


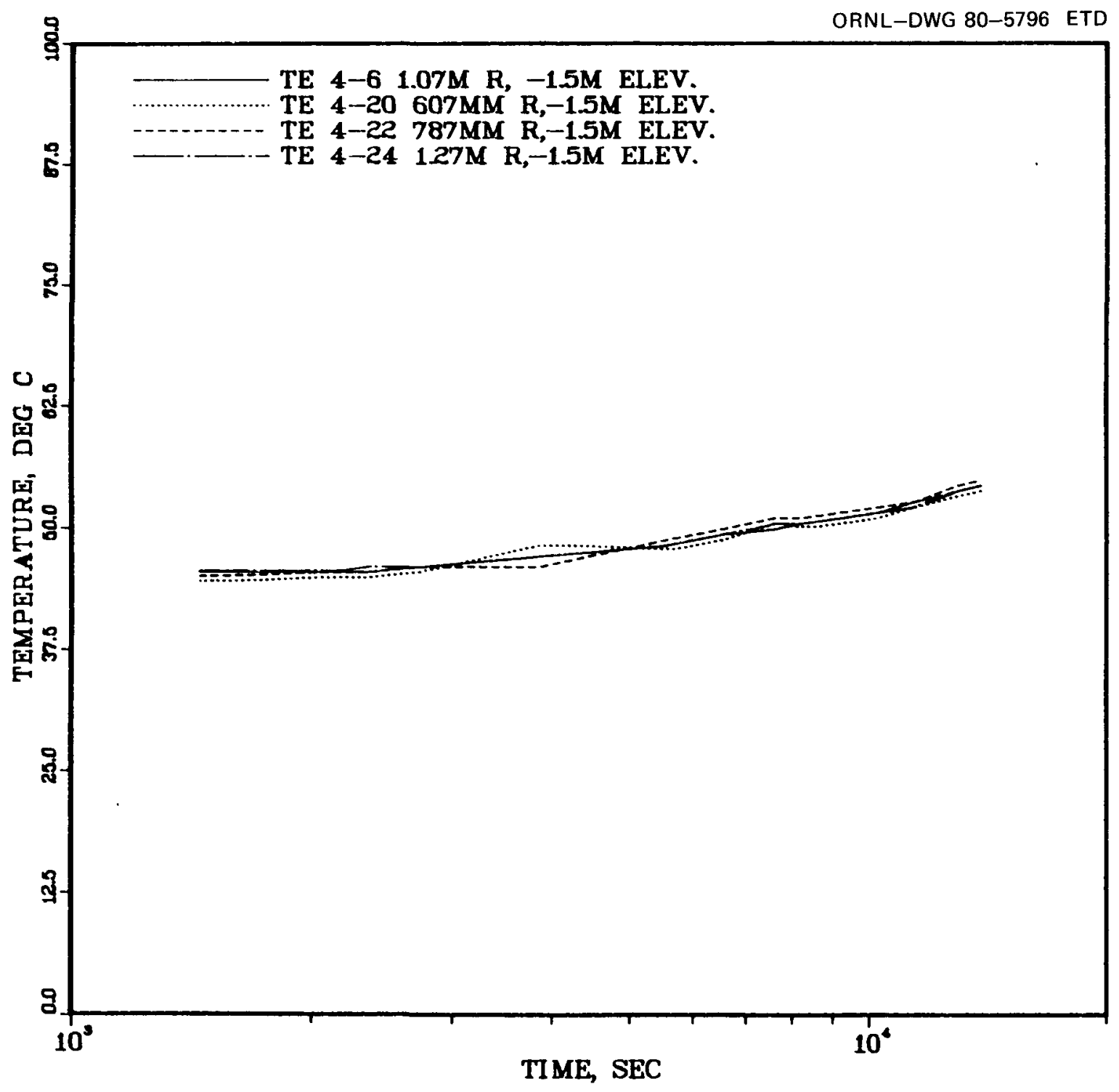

Fig. 74. Temperature measurements at $1.5 \mathrm{~m}$ below vessel midplane-NSPP Test 206. 


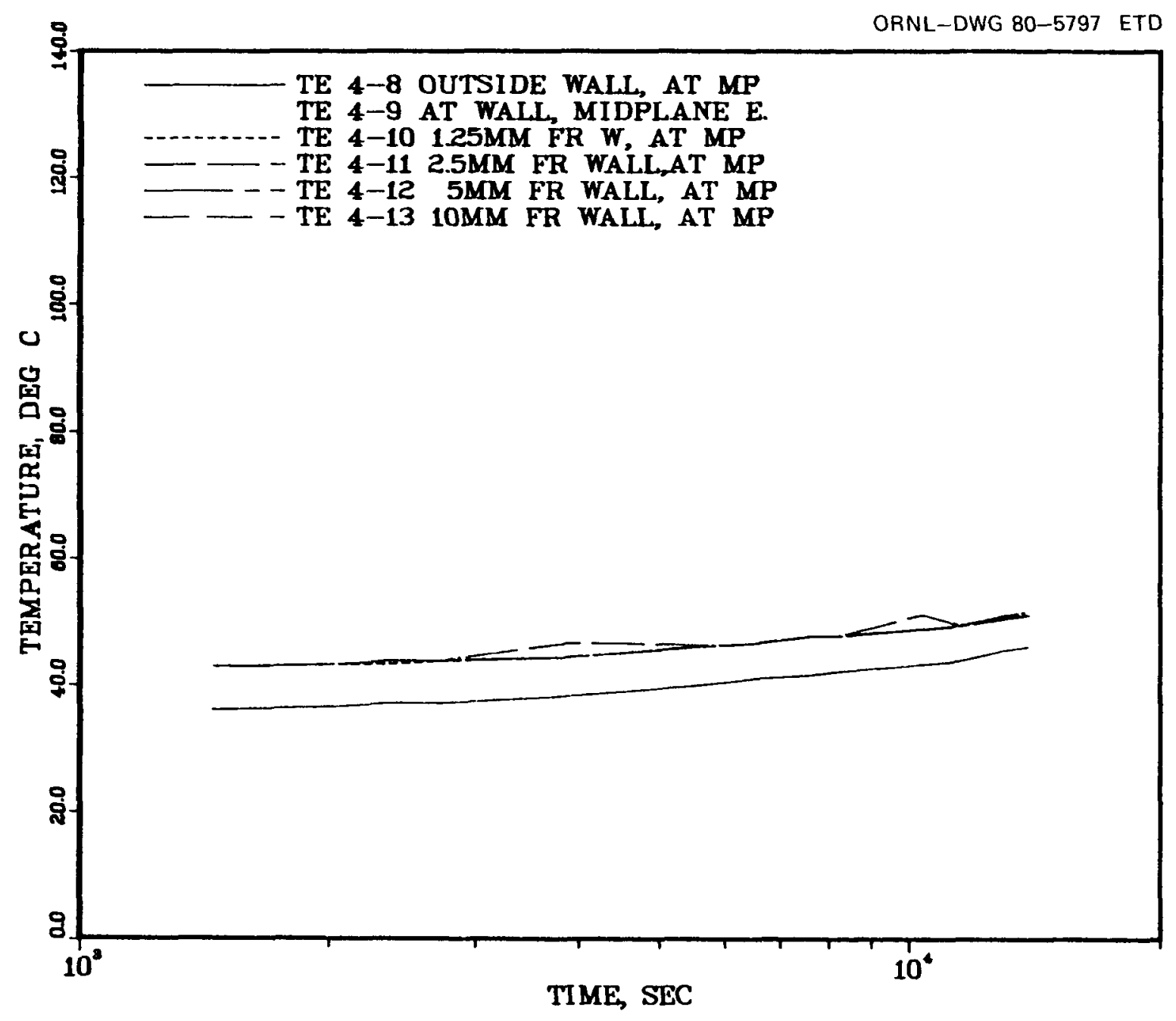

Fig. 75. Temperature measurements near the vessel wall at vessel midplane-NSPP Test 206. 


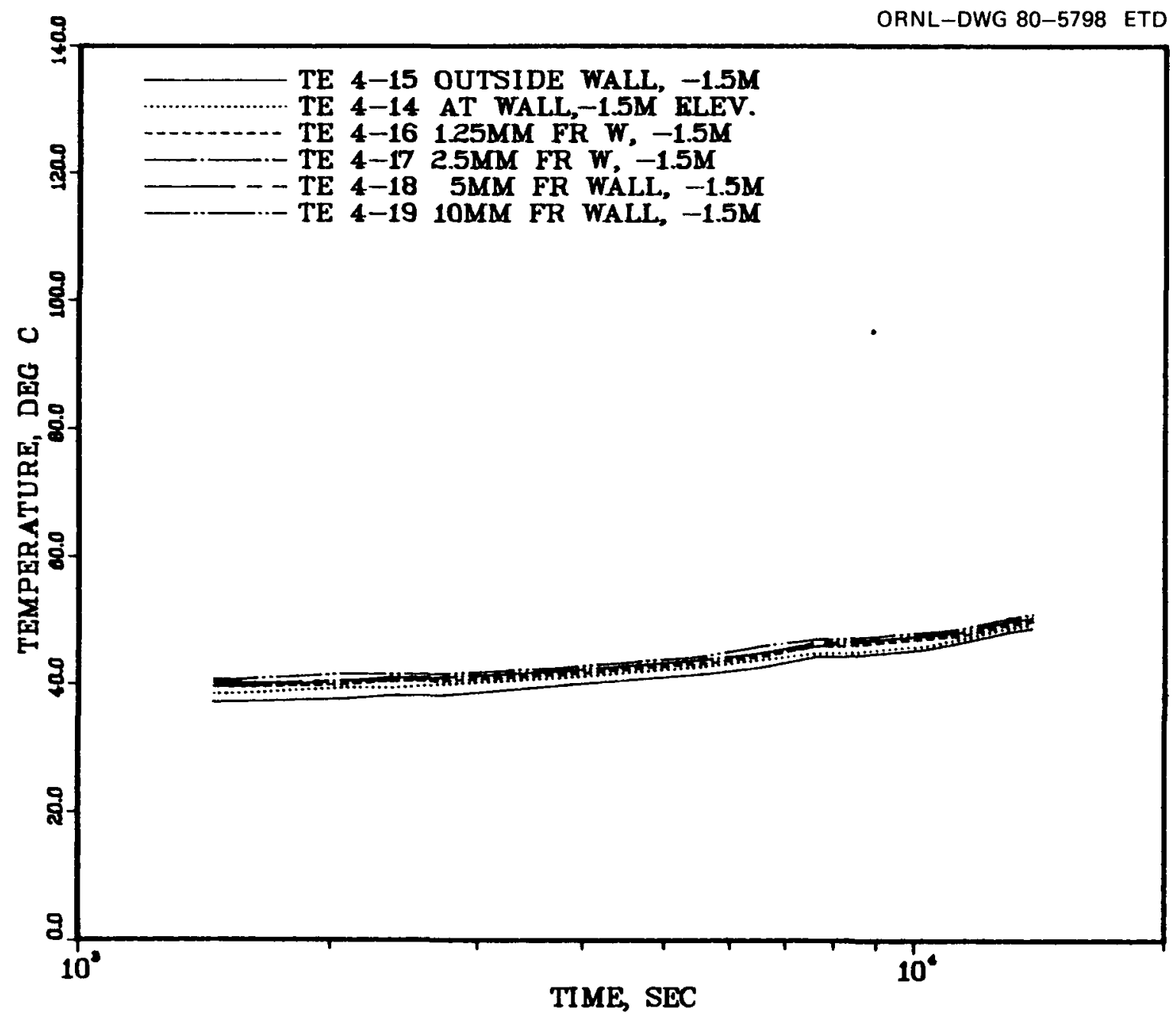

Fig. 76. Temperature measurements near the vessel wall at $1.5 \mathrm{~m}$ below vessel midplane-NSPP Test 206. 


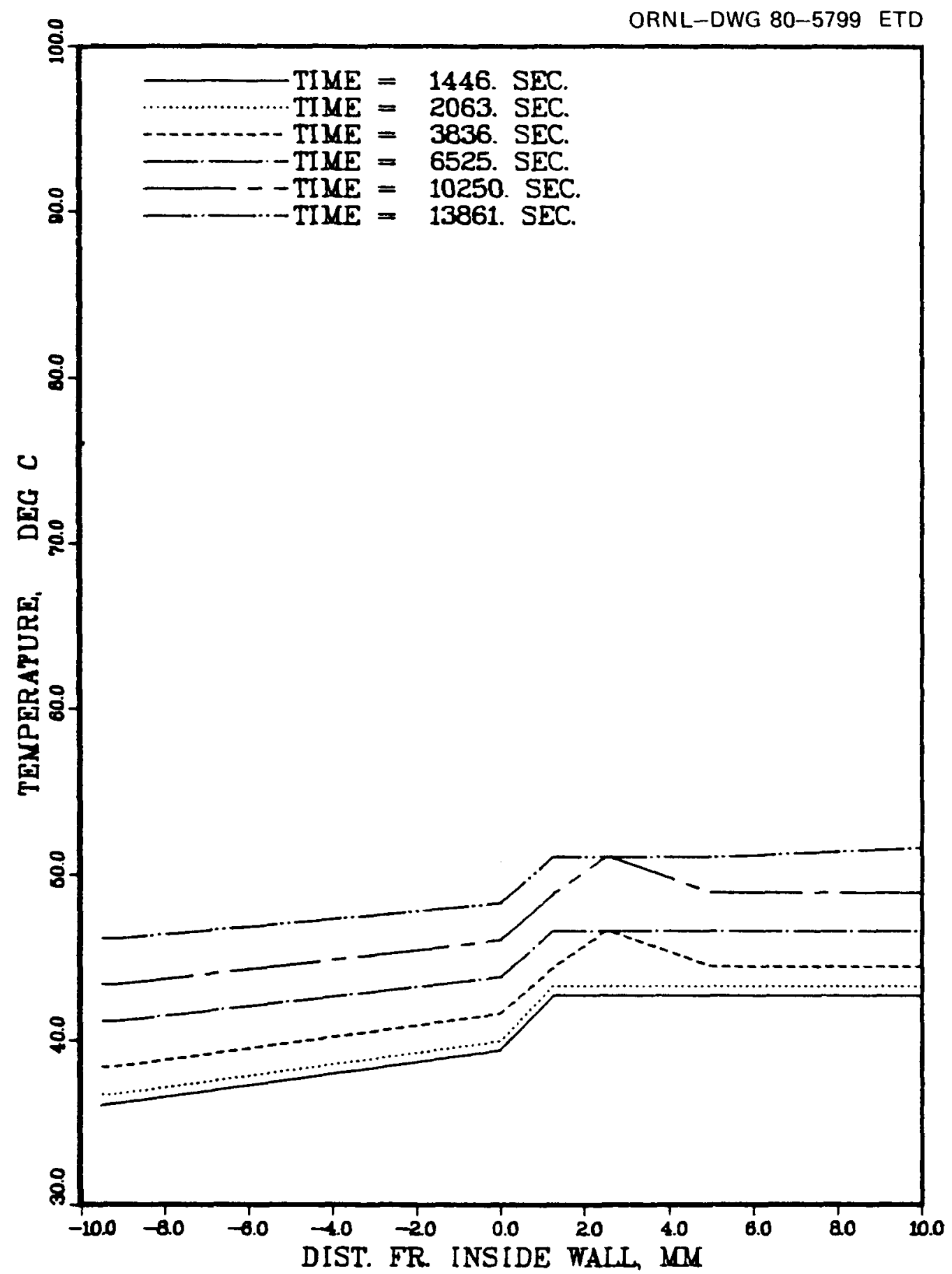

Fig. 77. Temperature profile near the vessel wall at midplane for various times after start of aerosol generation (note that the distance is measured from the inside wall toward the center of the vessel)-NSPP Test 205. 


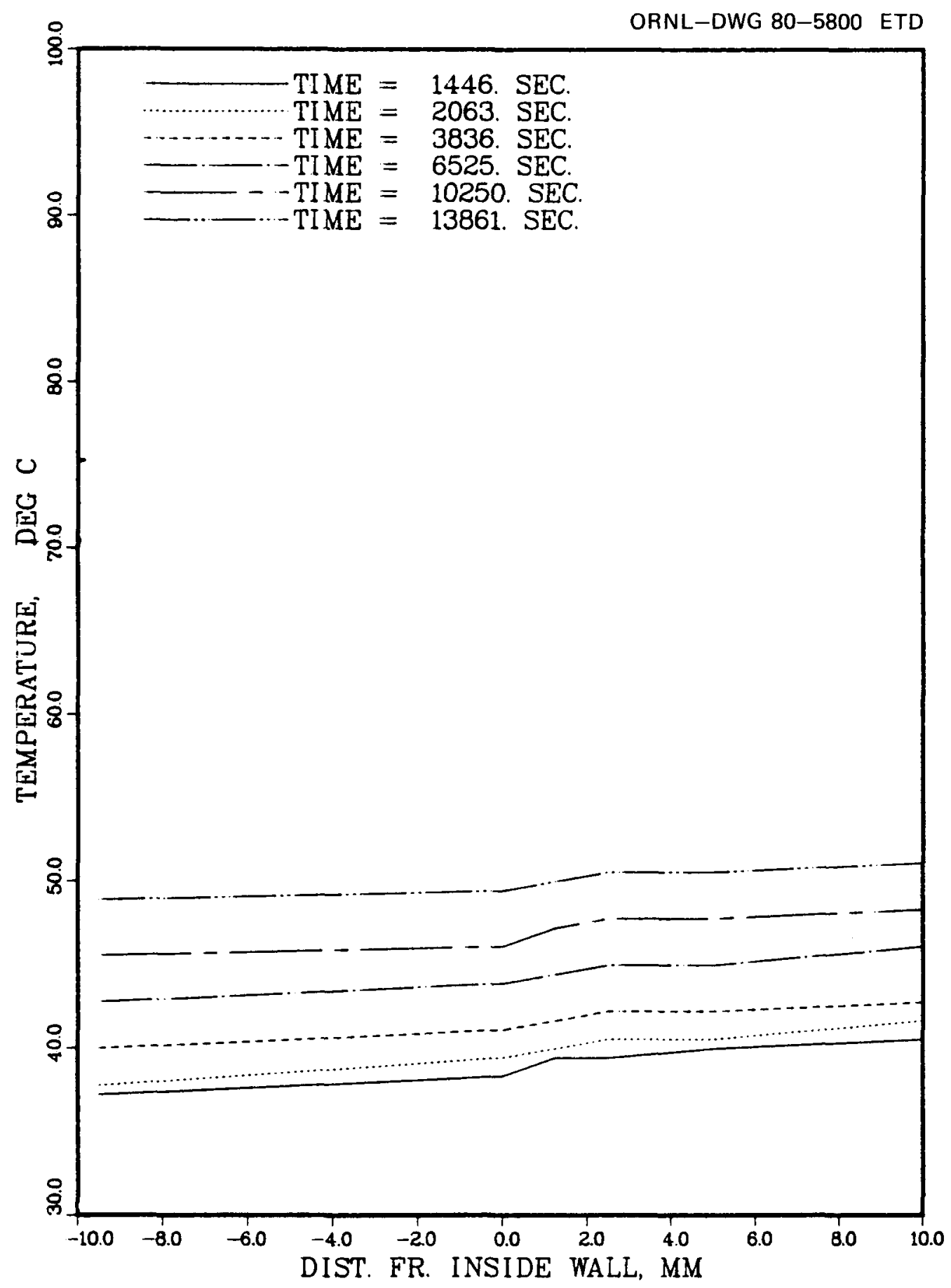

Fig. 78. Temperature profile near the vessel wall at $1.5 \mathrm{~m}$ below midplane for various times after start of aerosol generation-NSPP Test 206. 


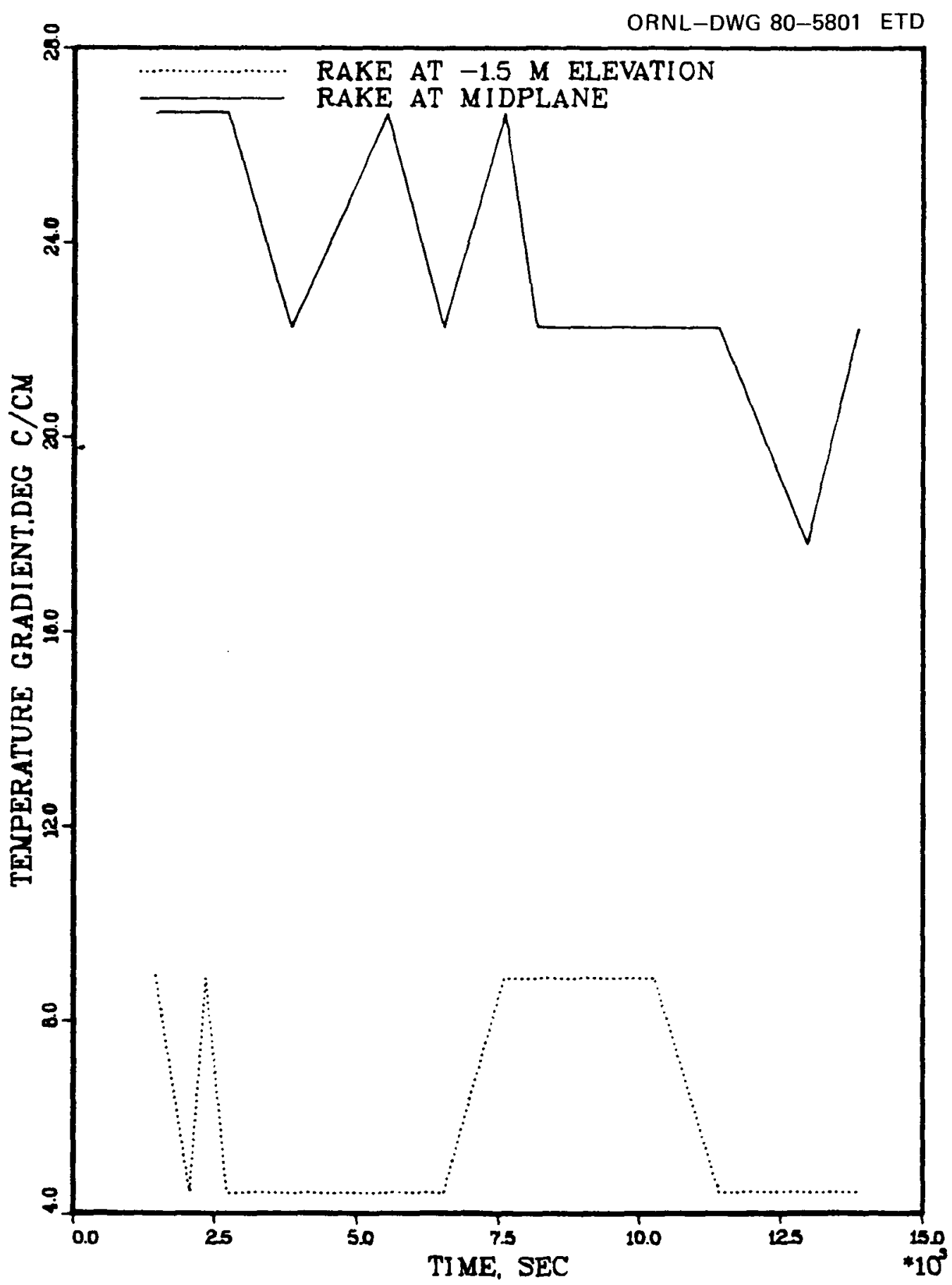

Fig. 79. Temperature gradient at the vessel wall for two elevations-NSPP Test 206. 


\subsection{Summary and Data Graphs for Test 207}

\section{Aerosol source}

Test aerosol used

$\mathrm{U}_{3} \mathrm{O}_{8}$

Aerosol generator

Plasma torch

Duration of aerosol generation

$26 \mathrm{~min}$

\section{Vessel atmosphere prior to aerosol generation}

Oxygen level

$21 \%$

Relative humidity

$<20 \%$

Temperature

Ambien

Pressure

Ambient

Duration of test operations

$48 \mathrm{~h}$

\section{Aerosol parameters measured and figure number}

Mass concentration of aerosol

Fig. 80

Aerosol fallout rate

Fig. 81

Aerosol plateout rate

Fig. 82

Cumulative mass fallout and plateout

Fig. 83

Aerosol particle size

Table 8

\section{System parameters measured and figure number}

Vessel atmosphere pressure

Fig. 84

Vessel atmosphere temperatures

Figs. $85-87$

Thermal gradients at vessel wall

Figs. 88-92

Posttest results

Maximum aerosol concentration achieved

$3.3 \mu \mathrm{g} / \mathrm{cm}^{3}$

Aerosol distribution at end of test

Still suspended in vessel atmosphere

$0.01 \%$

Plated onto internal surfaces

$47.7 \%$

Settled onto vessel floor

$52.3 \%$

Table 8. Andersen impactor data - Test 207

\begin{tabular}{|c|c|c|c|c|c|c|c|}
\hline \multirow{2}{*}{$\begin{array}{l}\text { Aerodynamic } \\
\text { mass median } \\
\text { diameter } \\
(\mu \mathrm{m})\end{array}$} & \multicolumn{7}{|c|}{ Sample No." } \\
\hline & $\begin{array}{c}1 \\
(25.2 \mathrm{~min})\end{array}$ & $\begin{array}{c}2 \\
(61.5 \mathrm{~min})\end{array}$ & $\begin{array}{c}3 \\
(108 \mathrm{~min})\end{array}$ & $\begin{array}{c}4 \\
(223 \mathrm{~min})\end{array}$ & $\begin{array}{c}5 \\
(346 \mathrm{~min})\end{array}$ & $\begin{array}{c}6 \\
(594 \mathrm{~min})\end{array}$ & $\begin{array}{c}7 \\
(1467 \mathrm{~min})\end{array}$ \\
\hline 13.7 & 89.1 & 96.5 & 92.1 & 96.2 & 96.4 & 99.0 & 95.1 \\
\hline 8.5 & 81.4 & 91.0 & 86.3 & 91.8 & 93.2 & 97.9 & 93.7 \\
\hline 5.8 & 72.5 & 79.7 & 76.8 & 81.3 & 88.1 & 95.8 & 92.3 \\
\hline 4.0 & 62.1 & 67.9 & 62.4 & 59.3 & 78.0 & 93.0 & 89.2 \\
\hline 2.5 & 50.1 & 48.8 & 38.4 & 38.9 & 59.7 & 80.3 & 83.7 \\
\hline 1.3 & 32.0 & 23.0 & 21.0 & 19.3 & 38.7 & 48.8 & 61.8 \\
\hline 0.78 & 19.0 & 10.2 & 9.2 & 8.5 & 18.7 & 23.2 & 31.3 \\
\hline 0.53 & 11.4 & 4.2 & 2.4 & 2.5 & 6.8 & 8.4 & 7.9 \\
\hline
\end{tabular}

${ }^{a}$ Percent of mass associated with diameters smaller than indicated size. 


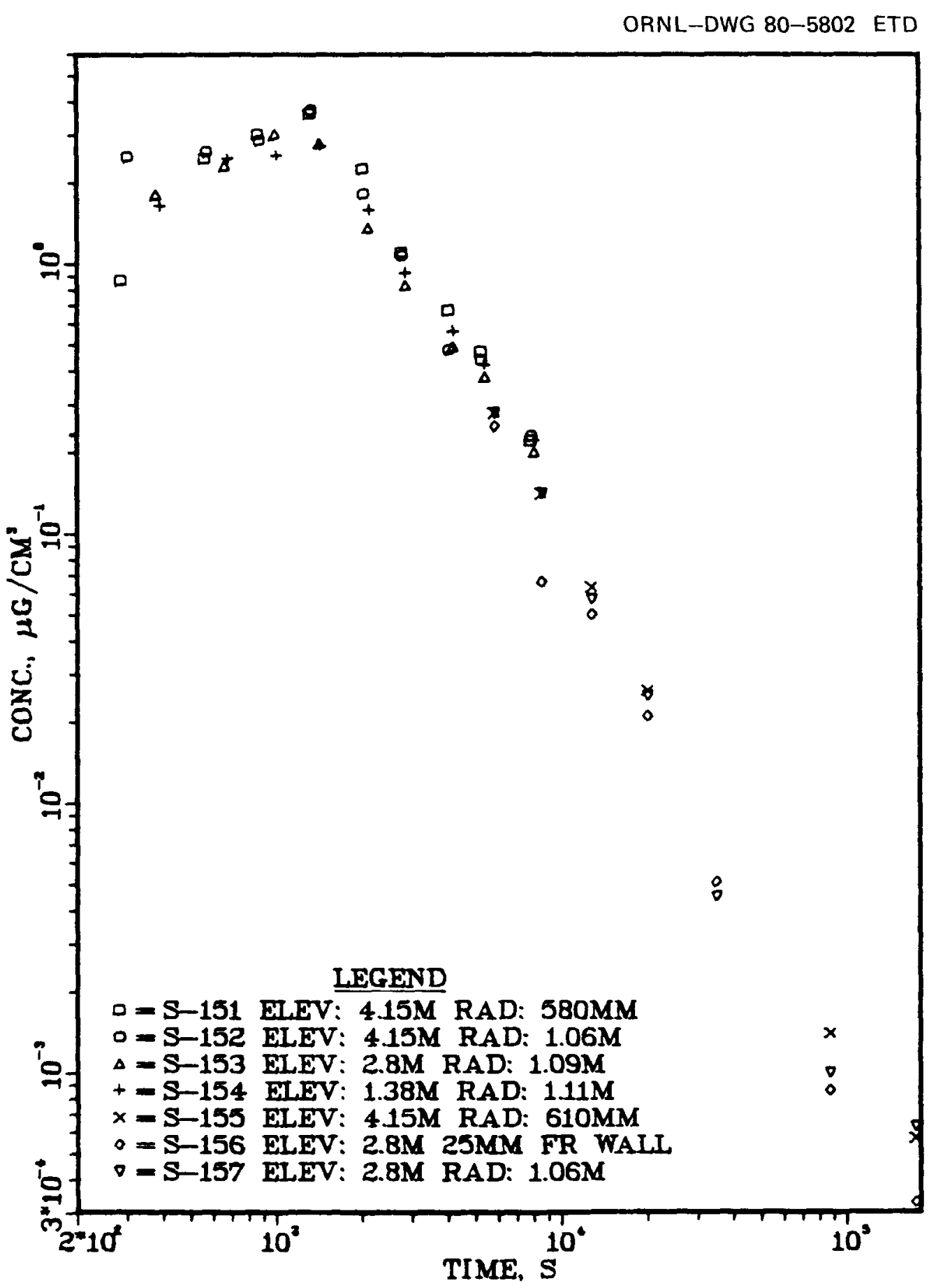

Fig. 80. Aerosol mass concentrations vs time-NSPP Test 207. 


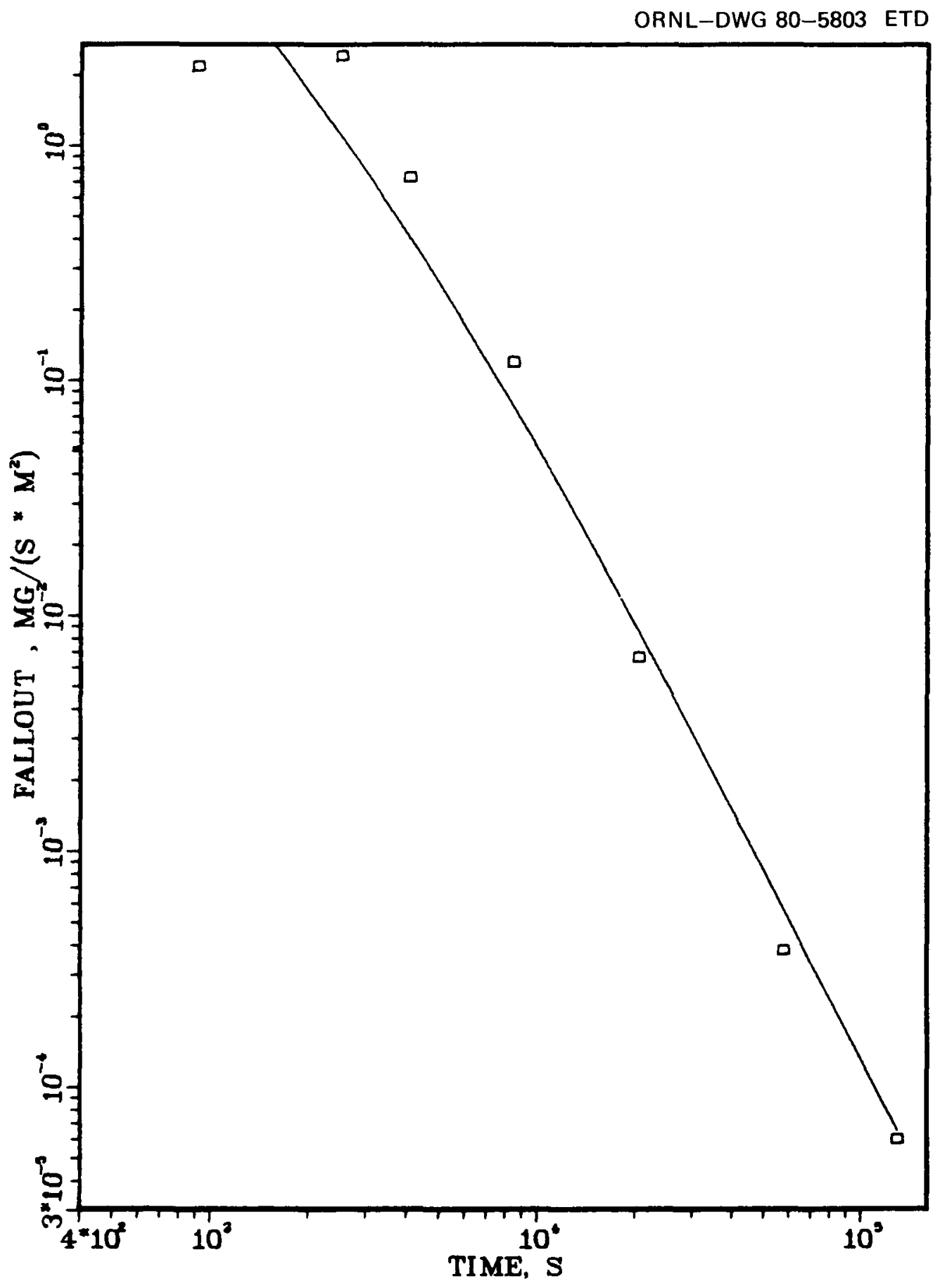

Fig. 81. Fallout rate vs time-NSPP Test 207. 


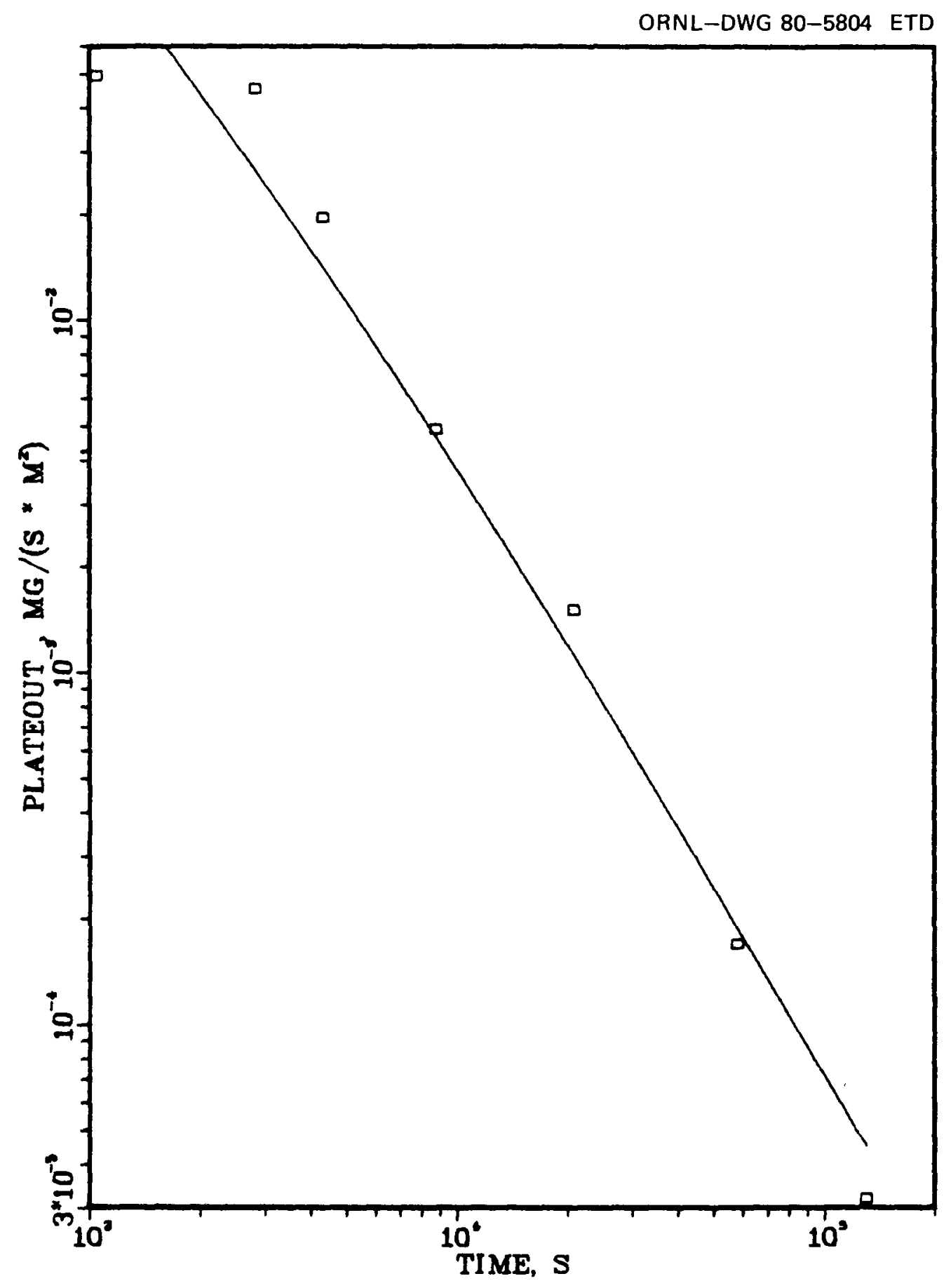

Fig. 82. Plateout rate vs time-NSPP Test 207. 


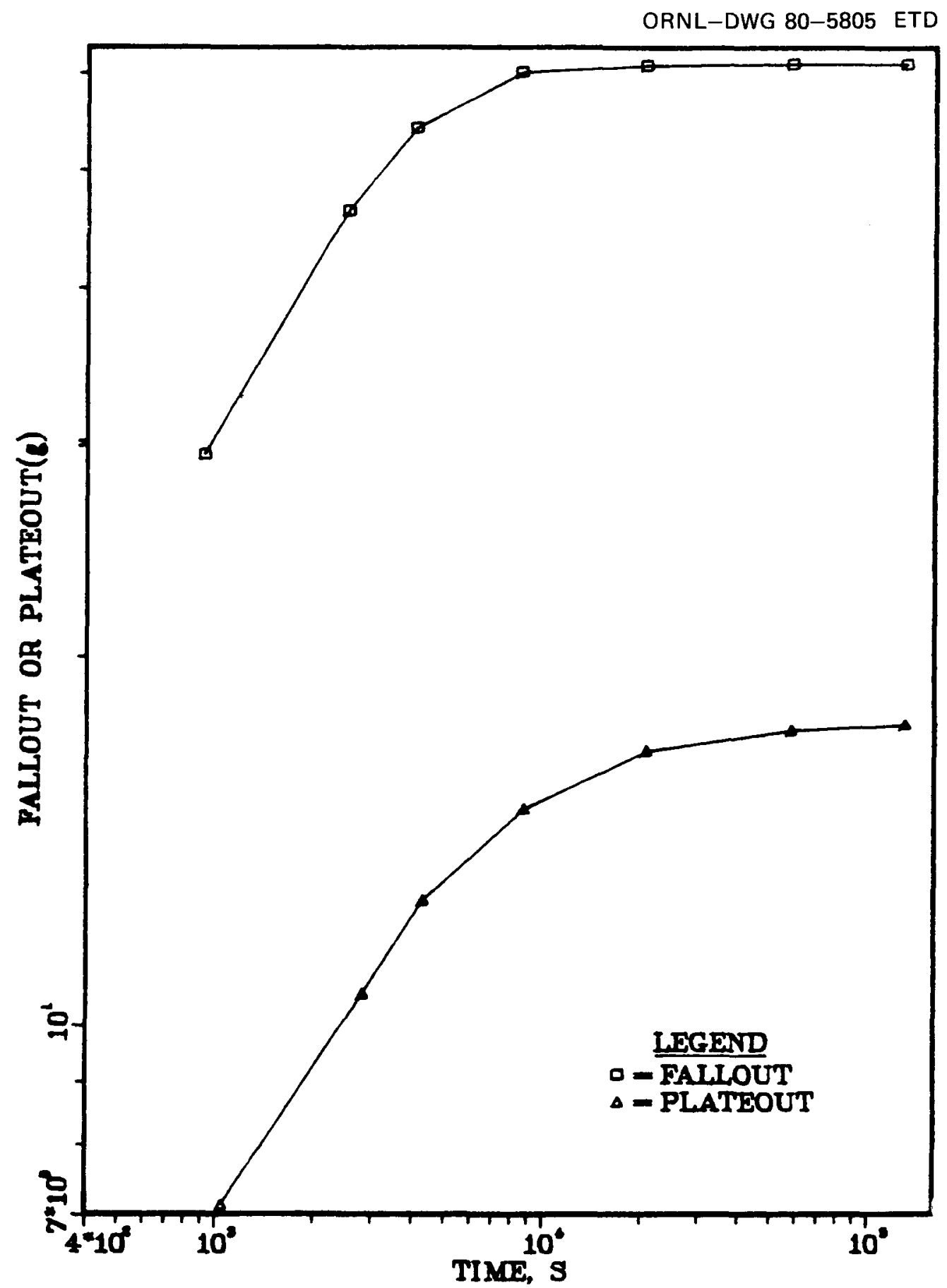

Fig. 83. Cumulative fallout and plateout mass vs time- NSPP Test 207. 


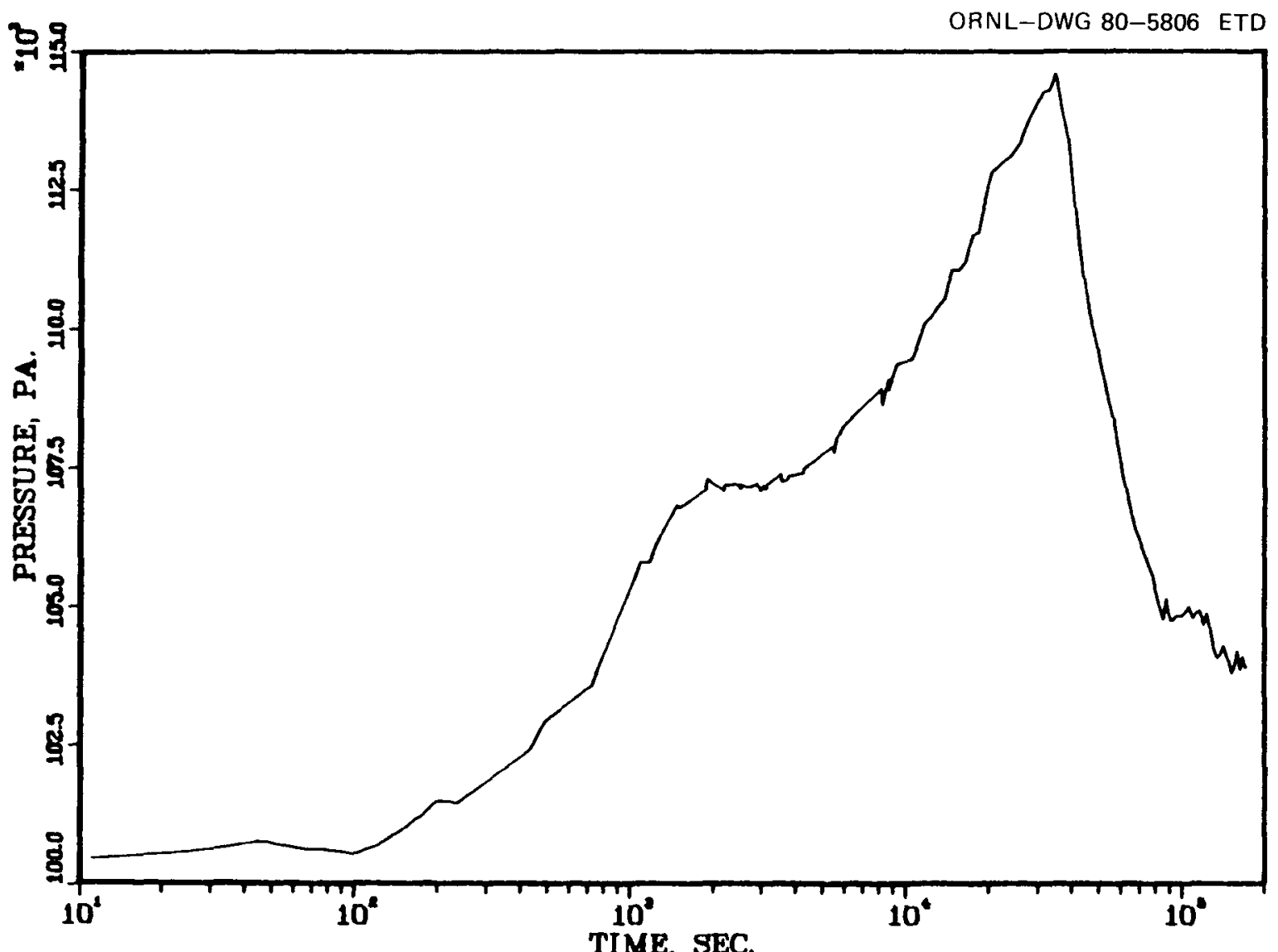

Fig. 84. In-vessel pressure vs time-NSPP Test 207. 


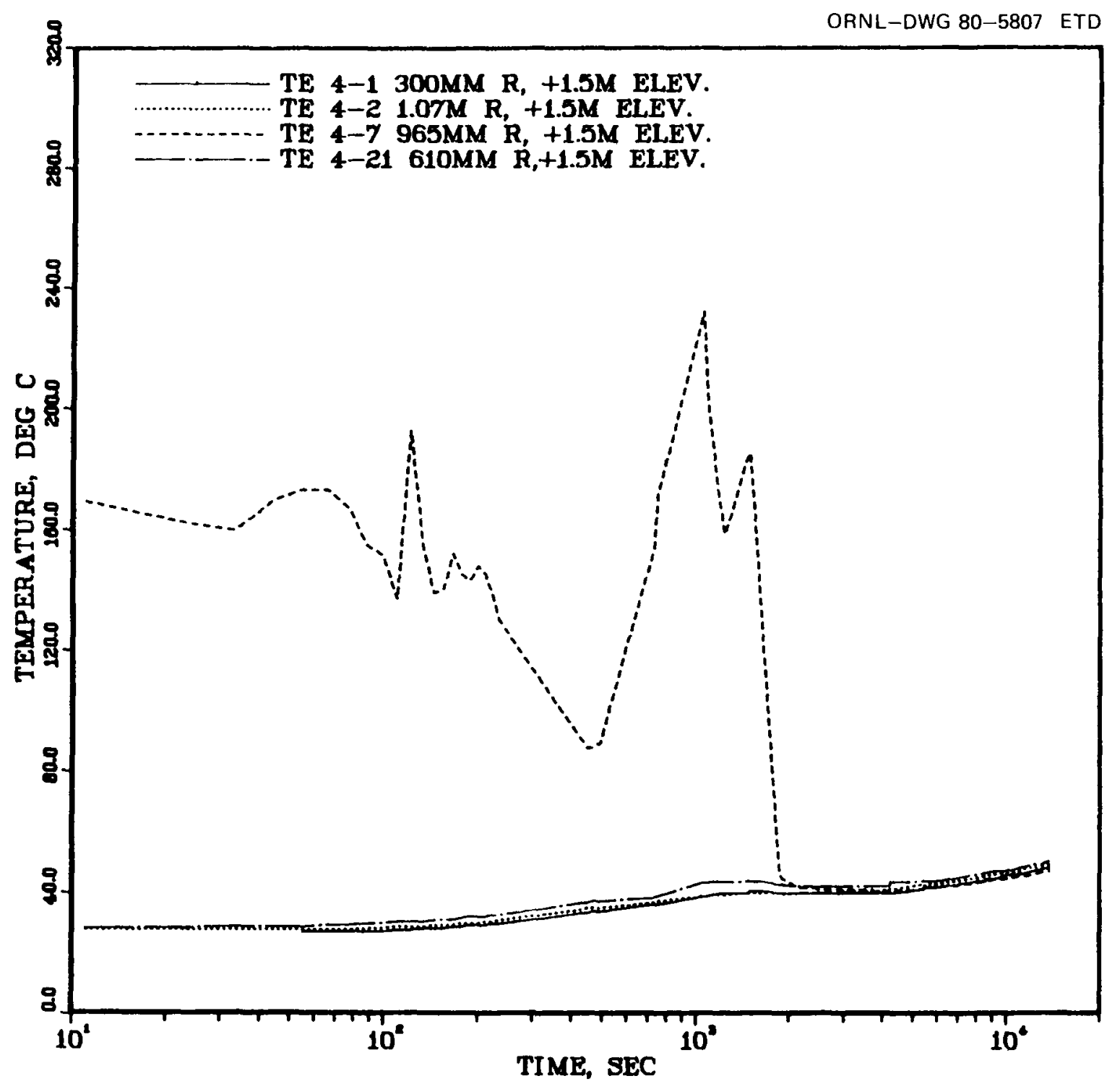

Fig. 85. Temperature measurements at $1.5 \mathrm{~m}$ above vessel midplane-NSPP Test 207. 


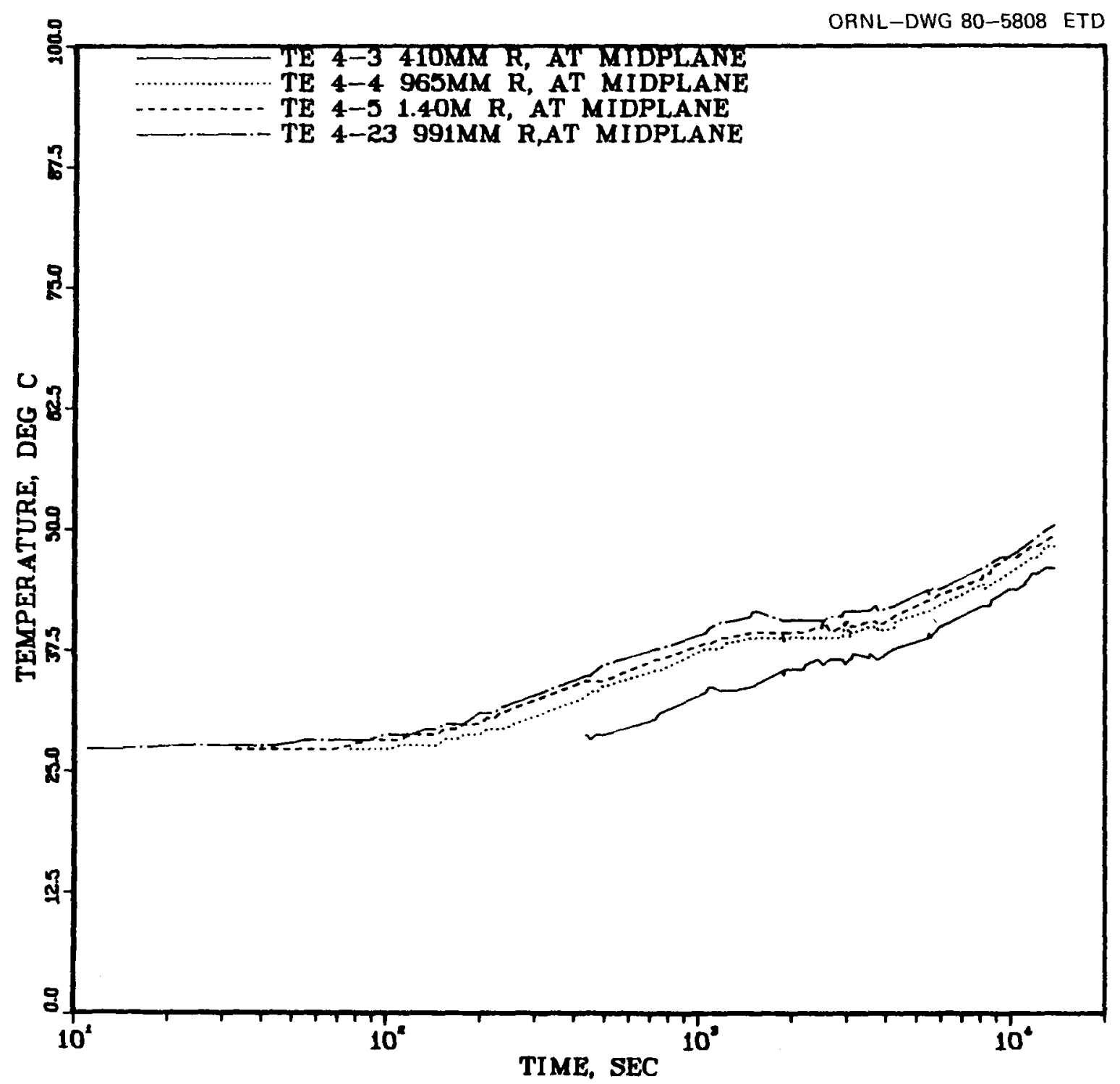

Fig. 86. Temperature measurements at vessel midplane-NSPP Test 207. 


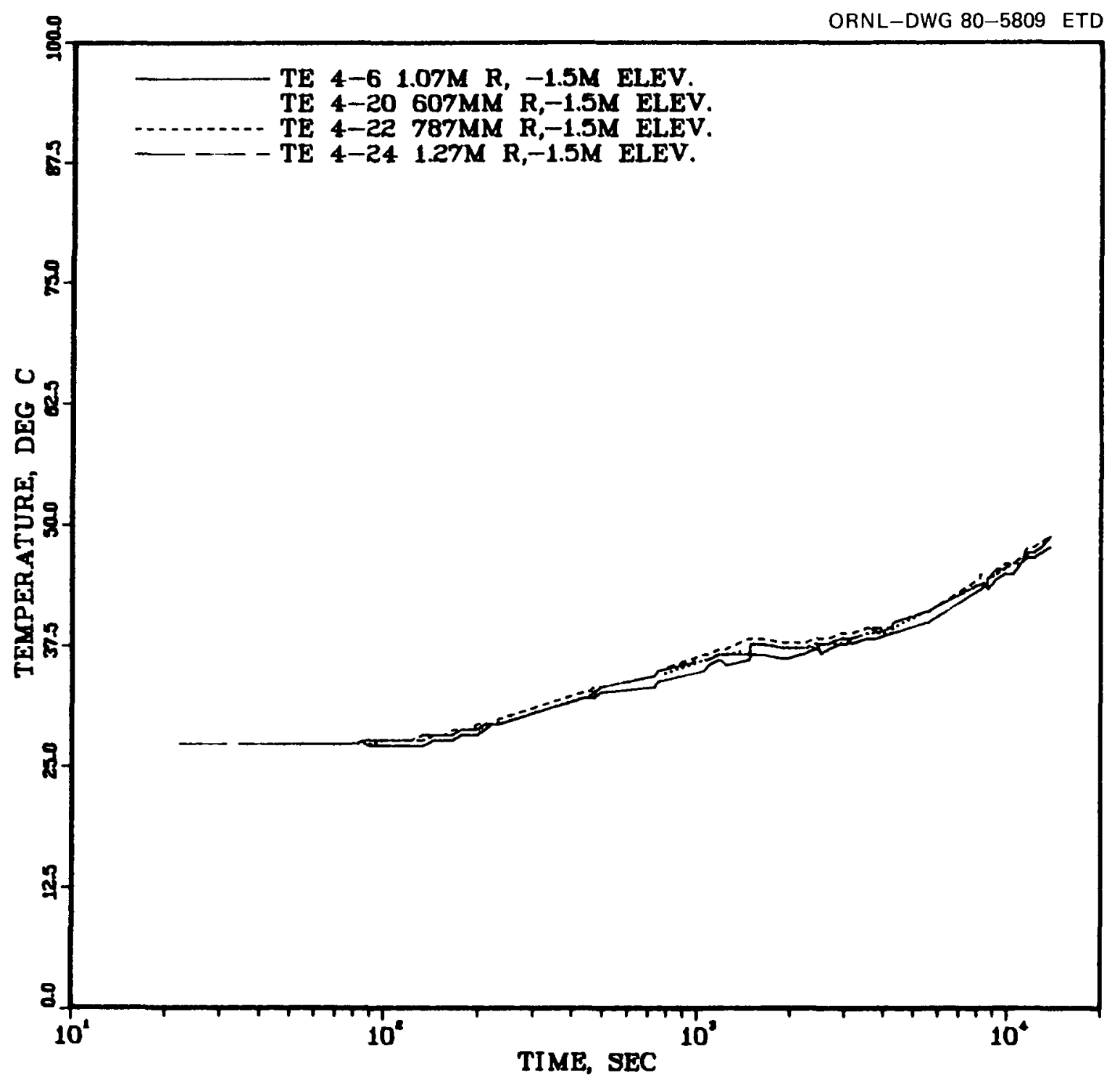

Fig. 87. Temperature measurements at $1.5 \mathrm{~m}$ below vessel midplane-NSPP Test 207. 


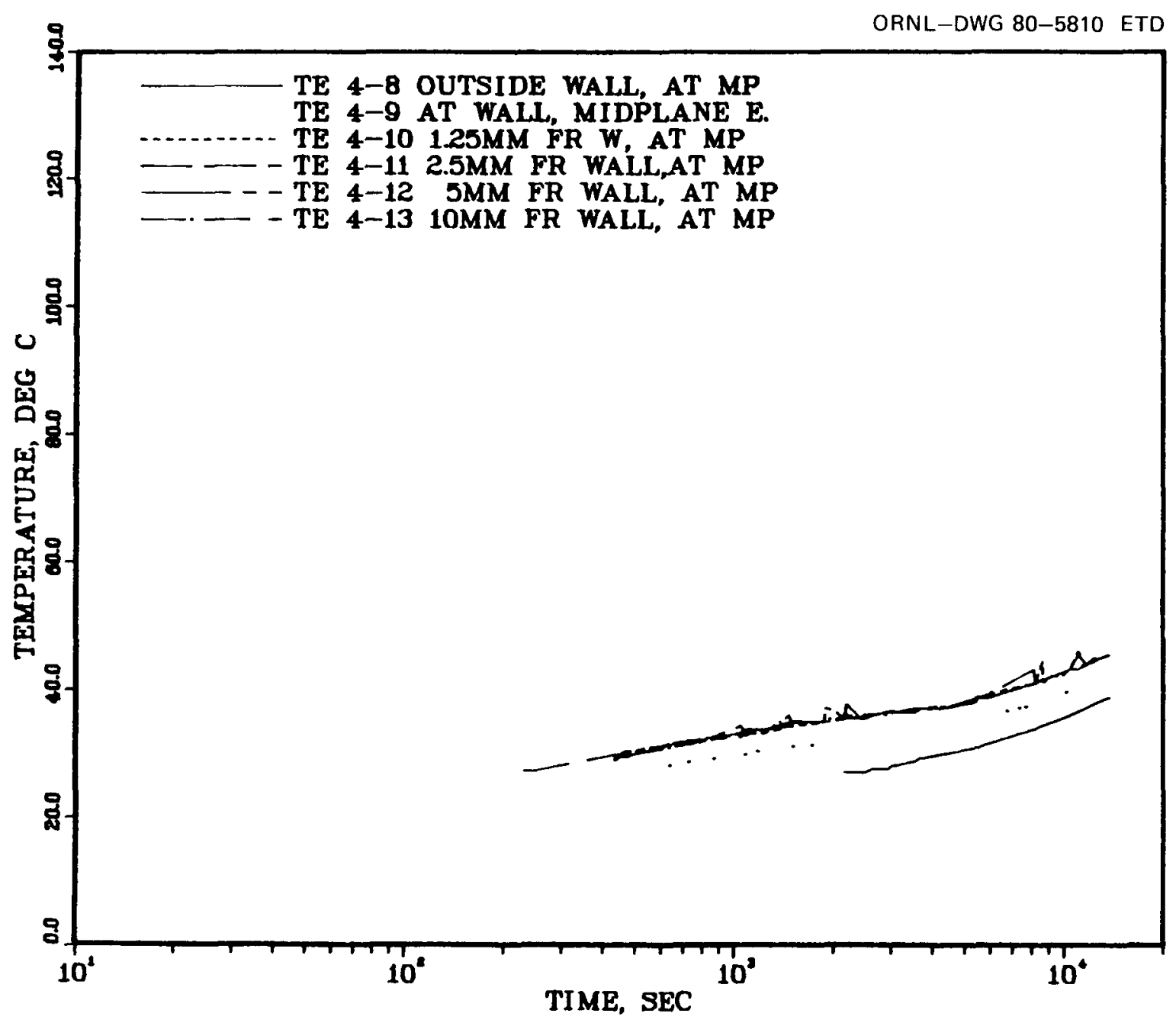

Fig. 88. Temperature measurements near the vessel wall at vessel midplane-NSPP Test 207. 


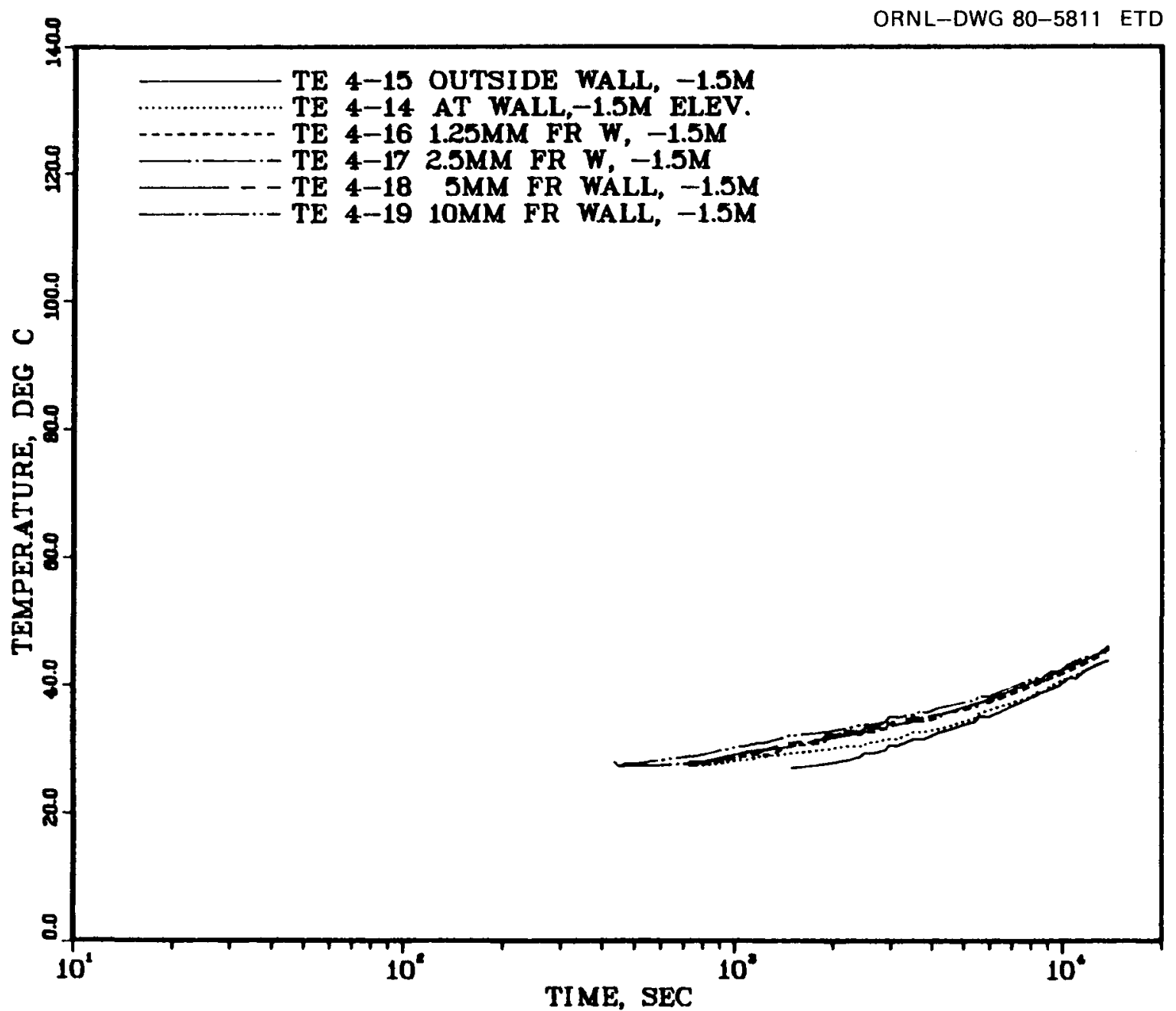

Fig. 89. Temperature measurements near the vessel wall at $1.5 \mathrm{~m}$ below vessel midplane-NSPP Test 207. 


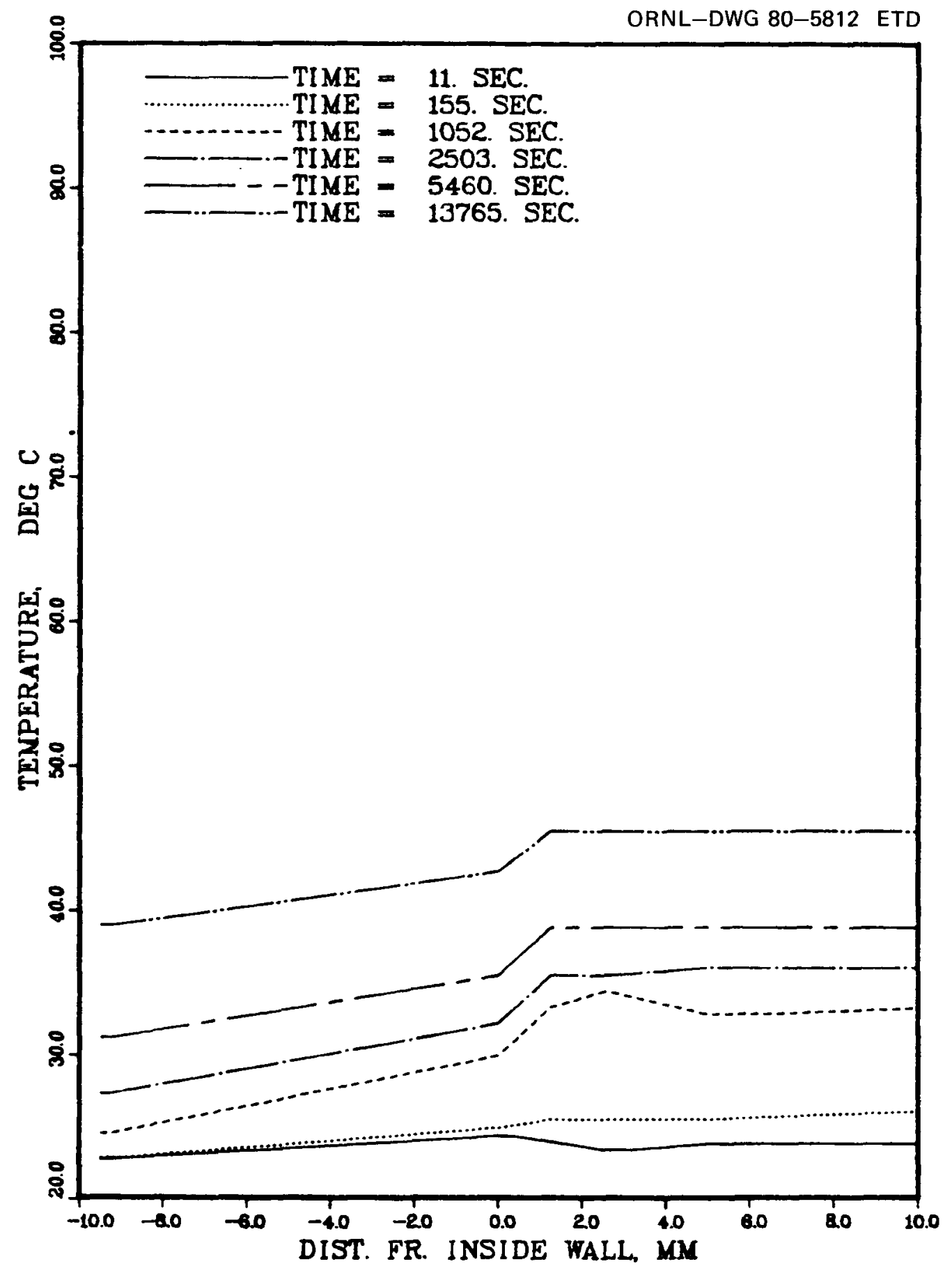

Fig. 90. Temperature profile near the vessel wall at midplane for various times after start of aerosol generation (note that the distance is measured from the inside wall toward the center of the vessel)-NSPP Test 207. 


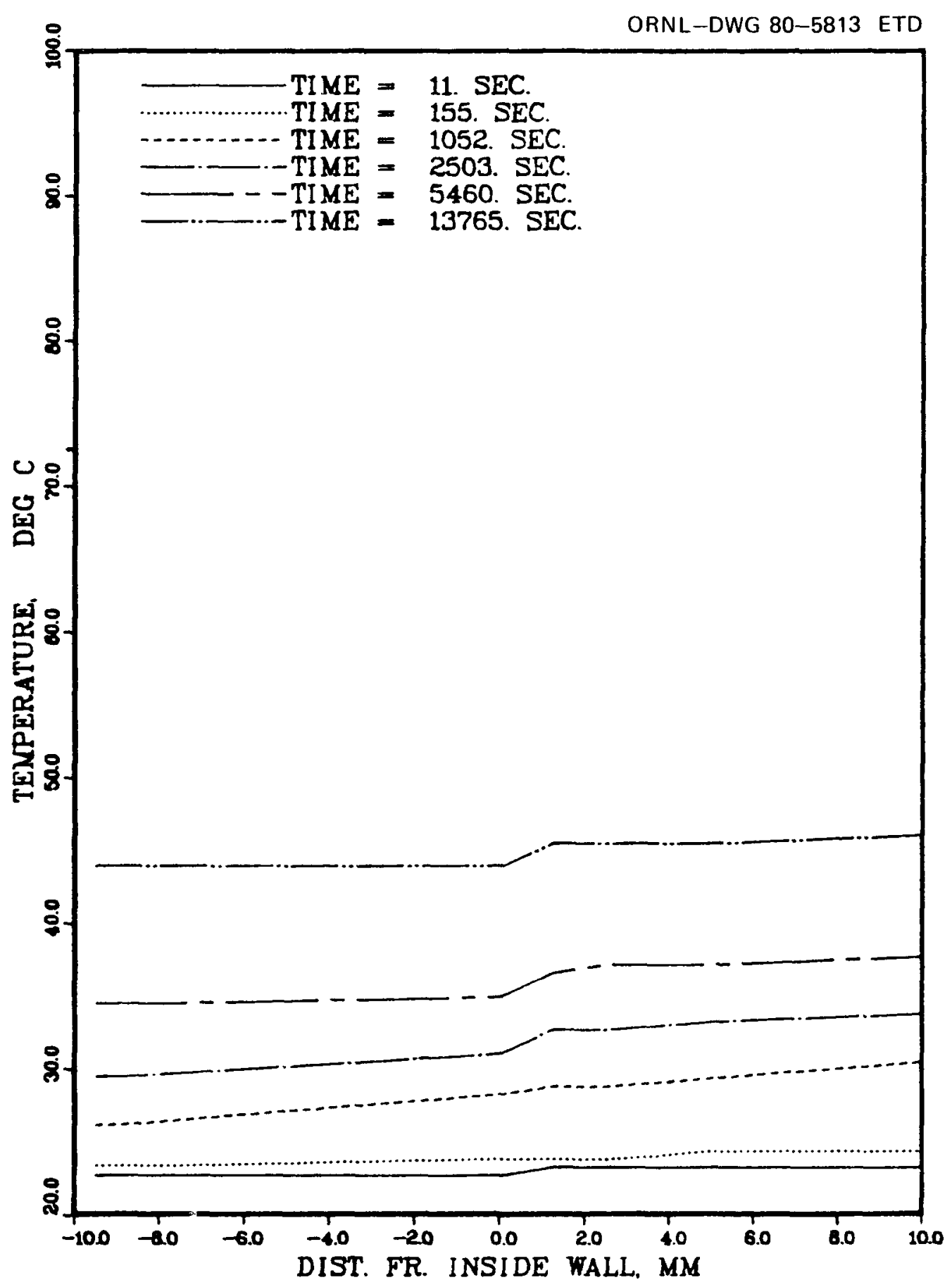

Fig. 91. Temperature profile near the vessel wall at $1.5 \mathrm{~m}$ below midplane for various times after start of aerosol generation-NSPP Test 207. 


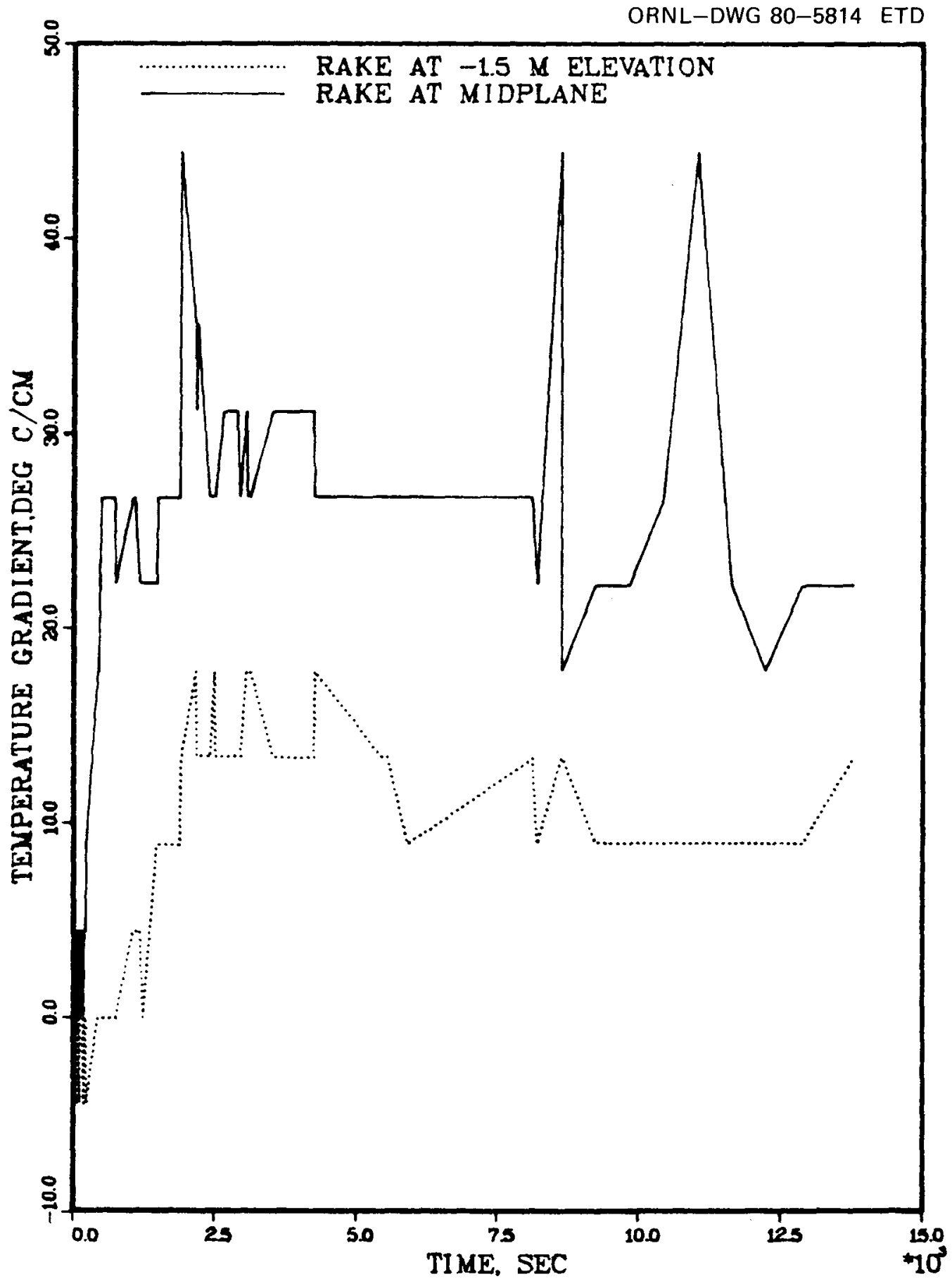

Fig. 92. Temperature gradient at the vessel wall for two elevations-NSPP Test 207. 


\section{REFERENCES}

1. R. E. Adams, T. S. Kress, and L. F. Parsly, Jr., Sodium Oxide Aerosol Study: NSPP Runs 101-105, Data Record Report, ORNL/NUREG/TM-179 (April 1978).

2. R. E. Adams, J. T. Han, T. S. Kress, and L. F. Parsly, Jr., Uranium and Sodium Oxide Aerosol Experiments: NSPP Tests 201-203 and Tests 301-302, Data Record Report, OR NL/NUREG/TM343 (November 1979).

3. T. S. Kress and A. L. Wright, LMFBR Aerosol Release and Transport Program Quarterly Progress Report for July-September 1978, ORNL/NUREG/TM-276 (January 1979). 
.

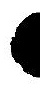




\section{Internal Distribution}

1-3. R. E. Adams

4. G. F. Flanagan

5. M. H. Fontana

6. H. W. Hoffman

7-11. T. S. Kress

12. F. R. Mynatt

13. G. W. Parker

14. J. L. Rich

15. J. A. Stevens
16. M. L. Tobias

17. H. E. Trammell

18. A. L. Wright

19. ORNL Patent Office

20. Central Research Library

21. Document Reference Section

22-23. Laboratory Records Department

24. Laboratory Records (RC)

\section{External Distribution}

25. R. Sherry, Division of Reactor Safety Research, Nuclear Regulatory Commission, Washington, D.C. 20555

26. M. Silberberg, Chief, Experimental Fast Reactor Safety Research Branch, Division of Reactor Safety Research, Nuclear Regulatory Commission, Washington, D.C. 20555

27-30. Director, Office of Nuclear Regulatory Research, Nuclear Regulatory Commission, Washington, D.C. 20555

31. Office of Assistant Manager for Energy Research and Development, DOE, ORO, Oak Ridge, Tenn. 37830

32-33. Technical Information Center, DOE, Oak Ridge, Tenn. 37830

34-413. Given distribution as shown in category R7 (NTIS-10) 